\title{
IUCN
}

\section{Integrated planning}

Policy and law tools for biodiversity conservation and climate change

Barbara Lausche

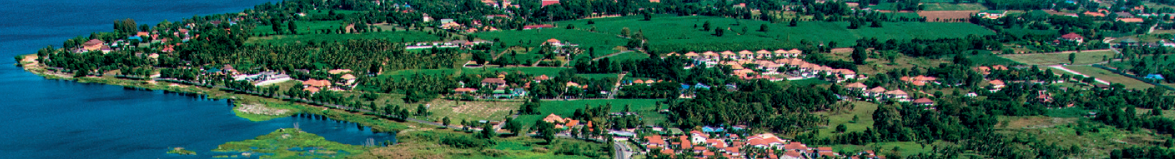

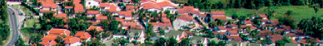

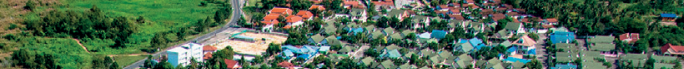

A

15.

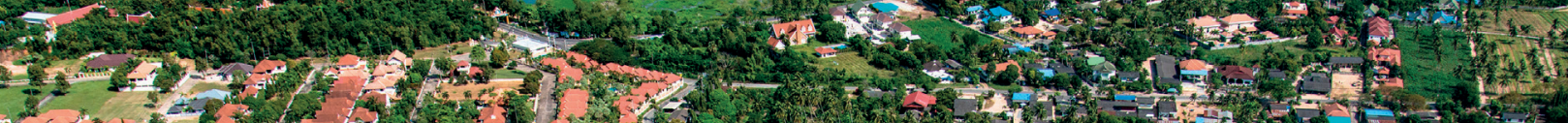
(2)

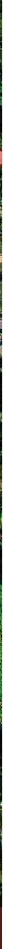

Supported by:

㴽

Federal Ministry
for the Environment, Nature Conservation

for the Environment
and Nuclear Safety

based on a decision of the German Bundesta 



\section{Integrated planning}

Policy and law tools for biodiversity conservation and climate change 



\section{Integrated planning}

Policy and law tools for biodiversity conservation and climate change

Barbara Lausche 
The designation of geographical entities in this book, and the presentation of the material, do not imply the expression of any opinion whatsoever on the part of IUCN, the International Climate Initiative (IKI) or the German Federal Ministry for the Environment, Nature Conservation and Nuclear Safety (BMU) concerning the legal status of any country, territory, or area, or of its authorities, or concerning the delimitation of its frontiers or boundaries.

The views expressed in this publication do not necessarily reflect those of IUCN, IKI or BMU.

This publication has been made possible in part by funding from the International Climate Initiative (IKI). The German Federal Ministry for the Environment, Nature Conservation and Nuclear Safety (BMU) supports this initiative on the basis of a decision adopted by the German Bundestag.

Published by:

IUCN, Gland, Switzerland in collaboration with the IUCN Environmental Law Centre, Bonn, Germany

Copyright:

(C) 2019 IUCN, International Union for Conservation of Nature and Natural Resources

Reproduction of this publication for educational or other non-commercial purposes is authorised without prior written permission from the copyright holder provided the source is fully acknowledged.

Reproduction of this publication for resale or other commercial purposes is prohibited without prior written permission of the copyright holder.

Citation:

Lausche, B. (2019). Integrated planning. Policy and law tools for biodiversity conservation and climate change. Gland, Switzerland: IUCN. xvi + 120 pp.

ISBN:

978-2-8317-1970-2 (PDF)

978-2-8317-1971-9 (Print)

DOI:

https://doi.org/10.2305/IUCN.CH.2019.EPLP.88.en

Cover photo:

(C) Praethip Docekalova /dreamstime.com

Layout by:

layout \& more, Bonn, Germany

Printed by:

Medienhaus Plump, Rheinbreitbach, Germany

Available from:

IUCN (International Union for Conservation of Nature)

Environmental Law Programme

Rue Mauverney 28

1196 Gland

Switzerland

Tel +41229990000

Fax +41229990002

elcsecretariat@iucn.org

www.iucn.org/resources/publications 


\section{Contents}

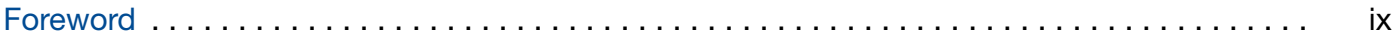

Acknowledgements $\ldots \ldots \ldots \ldots \ldots \ldots \ldots \ldots \ldots \ldots \ldots \ldots \ldots \ldots \ldots \ldots \ldots \ldots \ldots \ldots \ldots$

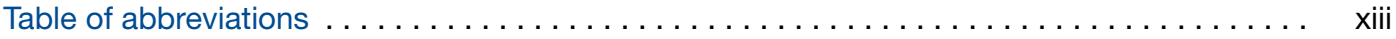

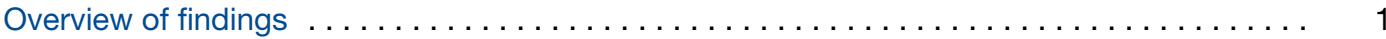

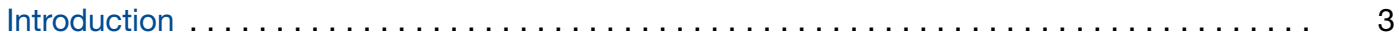

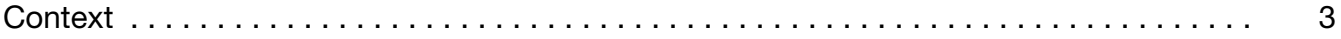

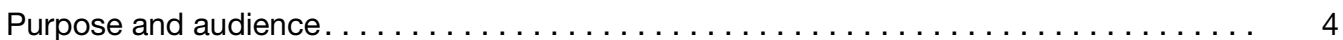

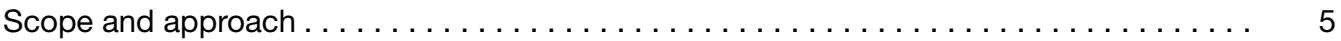

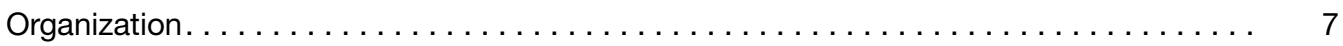

Key terms. . . . . . . . .

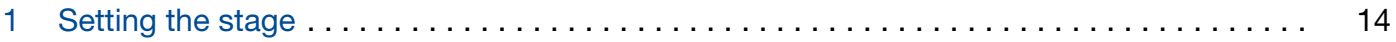

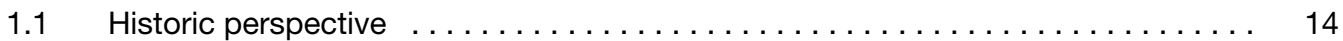

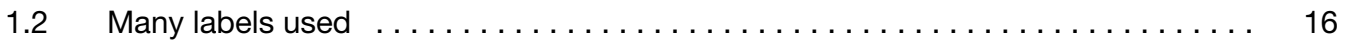

1.3 Common features of conventional land use/urban planning $\ldots \ldots \ldots \ldots \ldots \ldots$

1.4 Influence of the concept of 'sustainable development' $\ldots \ldots \ldots \ldots \ldots \ldots \ldots$

1.5 Influence of environmental thinking and climate change $\ldots \ldots \ldots \ldots \ldots \ldots \ldots 20$

1.6 Common features of modern spatial planning $\ldots \ldots \ldots \ldots \ldots \ldots \ldots \ldots \ldots \ldots . \ldots \ldots$

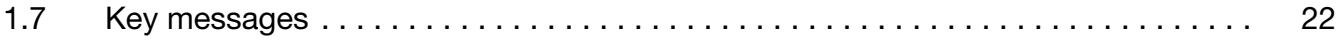

2 Advances in international law, science, and governance $\ldots \ldots \ldots \ldots \ldots \ldots \ldots \ldots \ldots$

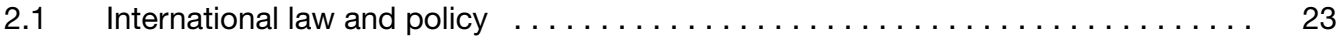

2.1.1 International law instruments - CBD and UNFCCC $\ldots \ldots \ldots \ldots \ldots \ldots \ldots 23$

2.1.2 Global policy - UN Sustainable Development Goals . . . . . . . . . . . 26

2.1 .3 Other relevant treaties and international programmes $\ldots \ldots \ldots \ldots \ldots \ldots . \ldots \ldots$

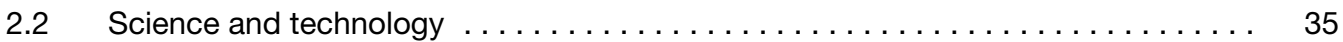

2.2.1 Conservation science, climate science, and integrated planning . . . . . 35

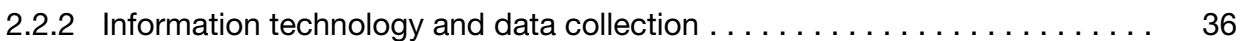

2.2.3 Global networks for information sharing $\ldots \ldots \ldots \ldots \ldots \ldots \ldots \ldots \ldots$

$2.3 \quad$ Governance . . . . . . . . . . . . . . . . . . . . . . . . . . . . . . 42

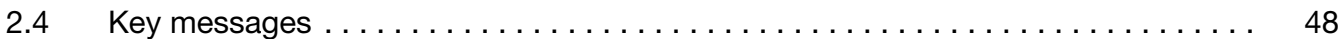

3 New elements for integrated spatial planning $\ldots \ldots \ldots \ldots \ldots \ldots \ldots \ldots \ldots \ldots \ldots$

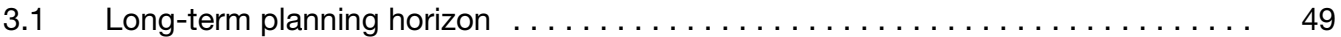

3.2 Definitions stress integration $\ldots \ldots \ldots \ldots \ldots \ldots \ldots \ldots \ldots \ldots \ldots \ldots \ldots \ldots$

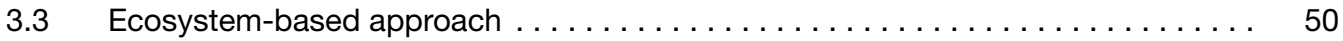

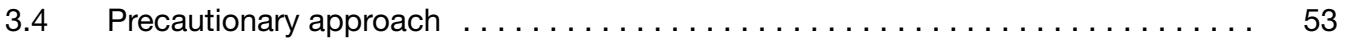

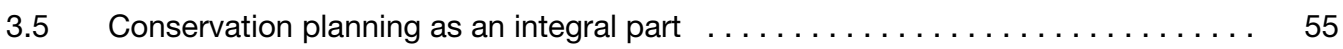

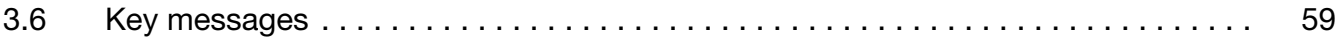


4 Benefits for biodiversity and ecosystem resilience $\ldots \ldots \ldots \ldots \ldots \ldots \ldots \ldots \ldots \ldots \ldots .60$

$4.1 \quad$ Advancing CBD strategic goals for biodiversity $\ldots \ldots \ldots \ldots \ldots \ldots \ldots \ldots \ldots$

$4.2 \quad$ Building resilience and adaptation for climate change $\ldots \ldots \ldots \ldots \ldots \ldots \ldots \ldots$

$4.3 \quad$ Integration of conservation plans and other sector plans $\ldots \ldots \ldots \ldots \ldots \ldots \ldots . \ldots 2$

4.4 Protecting connectivity for species and ecosystems $\ldots \ldots \ldots \ldots \ldots \ldots \ldots \ldots$

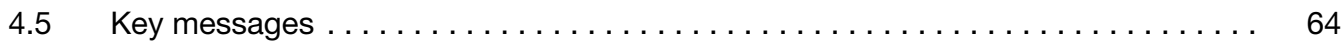

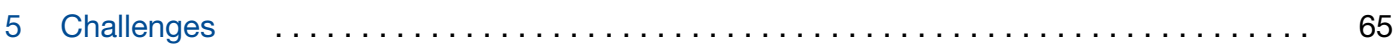

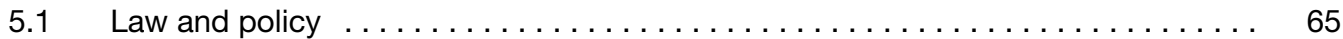

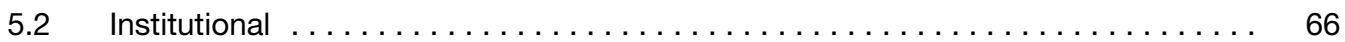

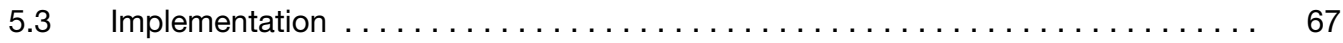

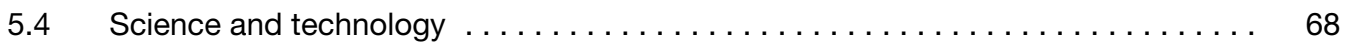

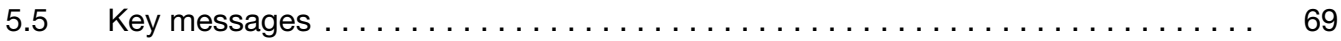

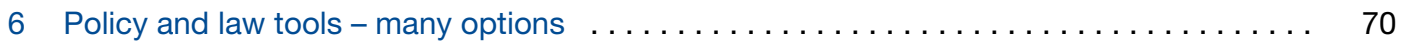

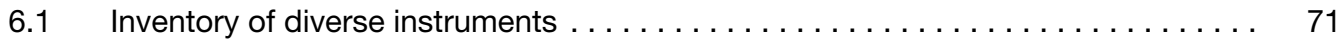

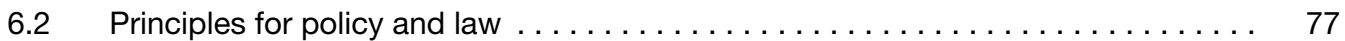

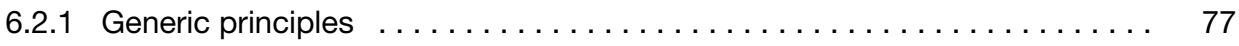

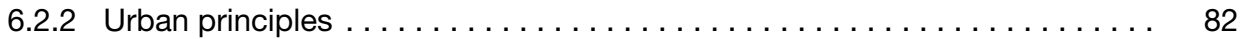

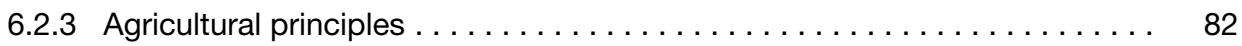

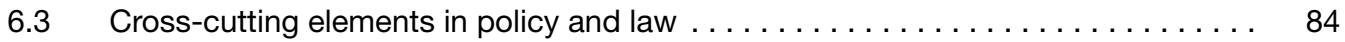

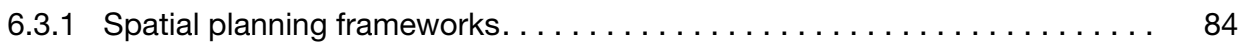

6.3 .2 Promote integrated planning. . . . . . . . . . . . . . . . . . . . . 86

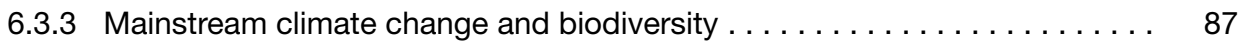

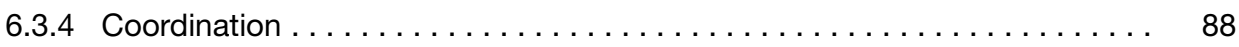

6.3.5 Data, mapping, forecasting and modeling $\ldots \ldots \ldots \ldots \ldots \ldots \ldots \ldots \ldots$

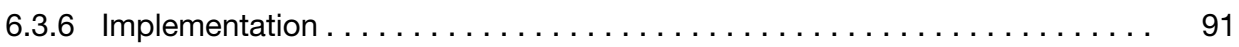

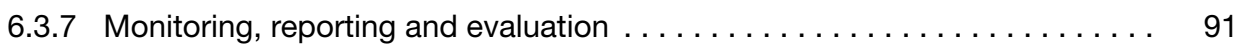

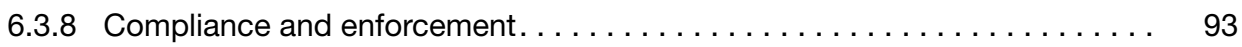

6.4 Highlights of subject-specific laws and policies $\ldots \ldots \ldots \ldots \ldots \ldots \ldots \ldots \ldots$

6.4 .1 Zoning . . . . . . . . . .

6.4.2 Permits and Development Permit Areas (DPAs) $\ldots \ldots \ldots \ldots \ldots \ldots \ldots \ldots$

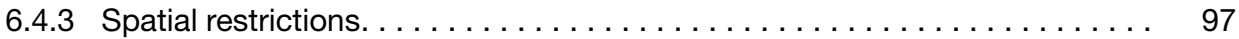

6.4.4 Environmental Impact Assessments and
Strategic Environmental Assessments $\ldots \ldots \ldots \ldots \ldots \ldots \ldots \ldots \ldots \ldots \quad 97$

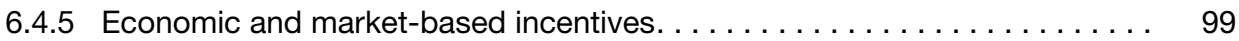

6.4 .6 Biodiversity offsets . . . . . . . . . . . . . . . . . . . . . 100

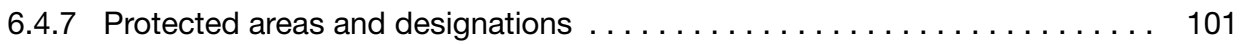

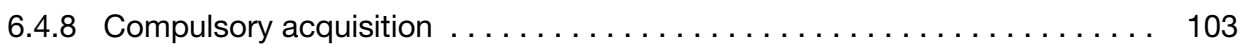

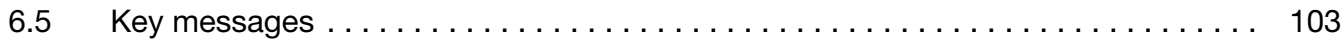




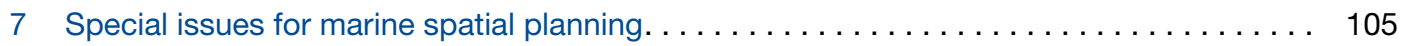

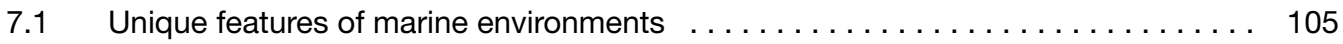

$7.2 \quad$ Marine spatial planning in practice $\ldots \ldots \ldots \ldots \ldots \ldots \ldots \ldots \ldots \ldots \ldots$

7.3 Major challenges for marine spatial planning law and policy $\ldots \ldots \ldots \ldots \ldots \ldots 108$

$7.4 \quad$ Key messages . . . . . . . . . . . . . . . 109

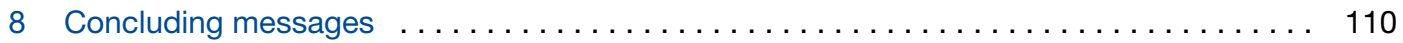

References and additional sources of information $\ldots \ldots \ldots \ldots \ldots \ldots \ldots \ldots \ldots \ldots \ldots$ 



\section{Foreword}

In recent years, it has become abundantly clear that spatial and land-use planning can adapt and expand to move beyond its traditional focus on settlements and infrastructure, to consider environmental and development issues in a broader and integrated landscape/seascape. But one challenge is how to rethink and modernize public sector planning to better guide future development to balance competing interests and to achieve sustainable development goals.

Borne out of the IUCN (International Union for Conservation of Nature) led project entitled "Integrated Planning to Implement the CBD Strategic Plan and Increase Ecosystem Resilience to Climate Change", this book focuses on the planning challenge and presents a menu of issues, concepts, and policy and law tools to aid governments and other governance actors in spatial planning for land and sea. From experience in a growing number of countries reviewed by the Project, key elements for modernization must include more comprehensive and long-range planning, ecosystem-based planning based on best available science, and policy integration across all government levels and sectors. These planning elements distinguish the emerging initiatives for integrated spatial planning from the narrower, more conventional land-use and urban planning systems started last midcentury. These new features are also critical, in particular, for advancing two global commitments of governments - conserving biodiversity and building ecosystem resilience in the face of climate change.

An associated change across the globe is the way governments work with and for their citizens. The book highlights the need for governments to develop and implement spatial planning processes and resulting plans in collaboration with relevant stakeholders in all sectors, levels of government, communities, groups, and affected interests. Such collaboration should be grounded in good governance principles, such as transparency, integrity and accountability of the public sector.

This book is a valuable addition to the dialogue, research, and emerging need to integrate and harmonize environment and planning tools to better guide future actions for sustainable development. It is our hope that this book will be an key resource for practitioners of I planning and planning law, elected representatives, civil society groups, local communities, researchers, students, and indeed any reader wishing to find their way towards a better understanding of this dynamic and emerging field.

We would like to express our gratitude to the International Climate Initiative of the German Federal Ministry for the Environment, Nature Conservation and Nuclear Safety (BMU) for the financial support of the project which enables the study and the publication of this book.

Dr. Alejandro Iza

Head, IUCN Environmental Law Programme

Director, IUCN Environmental Law Centre
Trevor Sandwith

Director, IUCN Global Protected

Areas Programme 



\section{Acknowledgements}

This publication is a joint effort of many people who have generously contributed their expertise, time and assistance. The IUCN Environmental Law Centre (ELC) and the author would like to thank them for their support and contributions towards production of this book.

As a first phase, in 2014 ELC reached out to a number of legal experts who provided detailed analyses of national legal frameworks on integrated planning in 16 countries:

Argentina (Marta Rovere)

Australia (Paul Martin)

Belgium (Bernard Vanheusden)

Bolivia (José María Chávez)

Brazil (Ricardo Pereira)

Cameroon (Nchunu Justice Sama)

Colombia (Gustavo Adolfo Guerrero Ruiz)

Germany (Wolfgang Köck and Moritz Reese)

Mongolia (lan Hannam)

The Netherlands (Kars de Graaf and Lorenzo Squintani)

South Africa (Alexander Paterson)

Tanzania (Hamudi Ismail Majamba and Laurean Mussa)

Turkey (Nilufer Oral)

USA (Melissa Powers)

Vietnam (Duong Van Ni)

Zambia (Daniel Sinjwala Libati)

These countries were selected based on their geographic representation, diversity of needs and conditions, and IUCN's reach and presence. The experts' work formed the basis to better understand the diversity of spatial planning processes worldwide. In July 2015, ELC hosted a workshop where a number of national experts met, exchanged national experiences and discussed common factors concerning integrated spatial planning, with particular attention to biodiversity conservation and climate change.

Based on the 16 national assessments, during 2015-2016, as part of this first phase, a global analysis was conducted by Joanna Kyriazis of the Laura Zizzo Professional Corporation (Canada) who extracted common themes and key messages. This draft global synthesis formed another valuable building block for this second phase: development of the current publication.

For this book, Professor Alexander Paterson from the Cape Town University of South Africa and Dr. Eddie Game, lead scientist, Asia Pacific Region of The Nature Conservancy, stationed in Australia, kindly reviewed and provided valuable substantive comments for improving and enriching its content. 
Special thanks go to Dr. Alejandro Iza, Director of the IUCN Environmental Law Centre (ELC), and Trevor Sandwith, Director of the IUCN Global Protected Areas Programme (GPAP), for their guidance throughout the work and their strategic oversight throughout both phases. Ning Li, ELC Programme Officer, deserves special thanks and recognition for her dedicated work to guide and manage particularly the final phase and ensure production of this publication. Also, as project co-managers for the first phase, special thanks go to former ELC legal officers, Santiago Martínez Ochoa, Katelijn Van Hende, and the late Warren Waetford. From the IUCN Global Protected Areas Programme, James Hardcastle and Jennifer Kelleher deserve special thanks for their contributions to the process and final draft. Valuable support and input have also been received from IUCN colleagues leading the project implementation at the national and regional levels, in particular Doyi Mazenzele, Leo Niskanen, Andrew Wyatt, Arturo Mora and Stephanie Arellano. Finally, thanks is due to all the staff of ELC who worked behind the scenes to provide essential support throughout the project. In particular, special thanks go to three individuals: Anni Lukács, Documentation and Information Officer, for managing the publication process, Monica Pacheco-Fabig, ELC Project Assistant, for compiling the acronyms and abbreviations and Ann DeVoy, Project Administrator, for the many administrative tasks involved.

We would also like to pay tribute to the late Dr. Françoise Burhenne-Guilmin whose idea inspired the conception of this project. We will always be grateful for the legacy she left us all, and to which we will always aspire.

Due to the complexity of this topic and the limited timeframe, we would like to note that this publication should be considered as an introduction (or first version) to the theme of integrated spatial planning. It introduces basic concepts, law and policy tools, and enabling conditions for countries to consider as part of building or strengthening their public sector planning to be more comprehensive and longrange in support of sustainable development goals. This requires, among other things, taking into account the spatial needs of biodiversity conservation and ecosystem resilience to climate change. We look forward to comments and suggestions to improve it in the future. 


\section{Table of abbreviations}

\begin{tabular}{|c|c|}
\hline AA & Appropriate Assessments \\
\hline ACC & Areas for Connectivity Conservation \\
\hline AEWA & African-Eurasian Waterbirds Agreement \\
\hline African & African Convention on the Conservation of Nature and Natural Resources \\
\hline APCRM & $\begin{array}{l}\text { Association des Pêcheurs de la Communauté Rurale de Mangagoulack } \\
\text { (Fishermen Association of the Rural Community of Mangagoulak) }\end{array}$ \\
\hline ASCOBANS & $\begin{array}{l}\text { Agreement on the Conservation of Small Cetaceans in the Baltic, North East, } \\
\text { Atlantic, Irish and North Seas }\end{array}$ \\
\hline Bern Convention & Convention on the Conservation of European Wildlife and Natural Habitats \\
\hline CAF & Cancun Adaptation Framework \\
\hline CBD & Convention on Biological Diversity \\
\hline CBD COP & CBD Conference of Parties \\
\hline CC:iNet & $\begin{array}{l}\text { Web-based clearinghouse for information sources on public information, } \\
\text { education and training in the field of climate change }\end{array}$ \\
\hline CMS & Convention on Migratory Species \\
\hline DDT & Dichlorodiphenyltrichloroethane \\
\hline DEFRA & UK Department for Environment, Food and Rural Affairs \\
\hline DPAs & Development Permit Areas \\
\hline EAAP & Ecosystem Approach Action Plan \\
\hline EEZ & Exclusive Economic Zone \\
\hline EIA & Environmental Impact Assessment \\
\hline ELC & Environmental Law Centre \\
\hline ETS & Emissions Trading Scheme \\
\hline EU & European Union \\
\hline FAO & Food and Agriculture Organization of the United Nations \\
\hline GBIF & Global Biodiversity Information Facility \\
\hline GES & Good Environmental Status \\
\hline GHG & Greenhouse Gas \\
\hline GIS & Geographic Information Systems \\
\hline GPAP & Global Protected Areas Programme \\
\hline ICCAs & Indigenous and Community Conserved Areas \\
\hline ICMPs & Integrated Coastal Zone Management Plans \\
\hline ICZM & Integrated Coastal Zone Management \\
\hline IMO & International Maritime Organization \\
\hline IOC & Intergovernmental Oceanographic Commission \\
\hline
\end{tabular}


IPBES

IPCC

IUCN

LID

LIFE

MAB

MARPOL

MEA

MoUs

MPA

MSP

NAP

NASA

Natura 2000

NBSAPs

NEAP

NEN

NGOs

NNN

NOAA

OECD

OECMs

OSPAR

PAGE

PES

PSSAs

REDD+

SBSTTA

SDGs

SEA

SSC

SVIR

TDRs

UK
Platform on Biodiversity and Ecosystem Services

Intergovernmental Panel on Climate Change

International Union for Conservation of Nature

Low-Impact Development

L'Instrument Financier pour l'Environnement

(EU's funding instrument for the environment and climate action)

Man and the Biosphere Programme

Convention for the Prevention of Pollution from Ships

Millennium Ecosystem Assessment

Memoranda of Understandings

Marine Protected Areas

Marine Spatial Planning

National Adaptation Plan

U.S. National Aeronautics and Space Administration

European Ecological Network

National Biodiversity Strategy and Action Plans

National Environmental Action Plans

National Ecological Networks

Non-governmental organizations

Natuurnetwerk Nederland

U.S.National Oceanic and Atmospheric Administration

Organization for Economic Co-operation and Development

Other Effective Conservation-based Measures

Convention for the Protection of the Marine Environment of the North-East

Atlantic

Partnership for Action on Green Economy

Payments for Ecosystem Services

Particularly Sensitive Sea Areas

Reducing Emissions from Deforestation and forest Degradation, programme under UNFCC

Subsidiary Body on Scientific, Technical and Technological Advice under CBD

Sustainable Development Goals

Strategic Environmental Assessment

Species Survival Commission

Structuurvisie Infrastructuur en Ruimte, Netherlands (National Policy Strategy for Infrastructure and Spatial Planning)

Tradable Development Rights

United Kingdom 


$\begin{array}{ll}\text { UN DESA } & \text { United Nations Department of Economic and Social Affairs } \\ \text { UN Environment } & \text { United Nations Environment Programme (formerly known as UNEP) } \\ \text { UN } & \text { United Nations } \\ \text { UNCLOS } & \text { UN Convention on the Law of the Sea } \\ \text { UNECE } & \text { United Nations Economic Commission for Europe } \\ \text { UNESCO } & \text { United Nations Educational, Scientific and Cultural Organization } \\ \text { UNEP-WCMC } & \text { UN Environment World Conservation Monitoring Centre } \\ \text { UNFCCC } & \text { United Nations Framework Convention on Climate Change } \\ \text { UNFF } & \text { United Nations Forum on Forests } \\ \text { UNITAR } & \text { United Nations Institute for Training and Research } \\ \text { USGS EROS } & \text { Earth Resources Observation and Science } \\ \text { USGS } & \text { U.S. Geological Survey } \\ \text { WCED } & \text { World Commission on Environment and Development } \\ \text { WCPA } & \text { World Commission on Protected Areas } \\ \text { WHC } & \text { World Heritage Convention } \\ \text { WWF } & \text { World Wildlife Fund }\end{array}$





\section{Overview of findings}

This book explores emerging concepts, challenges, and key policy and law tools to help inform governments as they modernize public sector planning to better address $21^{\text {st }}$ century change and advance their sustainable development goals. The focus is on strengthening spatial planning approaches to be more comprehensive, integrated, spatially and ecosystem oriented, and long-range. As part of such modernization, it becomes essential to incorporate biodiversity and climate change commitments as articulated and agreed by most countries particularly through the Convention on Biological Diversity (CBD) 2020 Strategic Plan for Biodiversity with its Aichi Targets, and the United Nations Framework Convention on Climate Change (UNFCCC) new initiatives to build ecosystem resilience to climate change. This is an underlying premise of the book.

Following preliminary chapters on historicl context, features of modern spatial planning along with benefits and challenges involved, Chapter 6 is the principal chapter dealing with specific policy and law principles and tools for strengthening spatial planning systems. The emphasis is on options, recognizing that some tools or approaches may not be appropriate or feasible at all or only in part. The main purpose of Chapter 6 is to explore how various law and policy tools, mostly already existing in national legal systems, can be used to support climate change and biodiversity objectives as an integral part of planning. That chapter offers mostly generic considerations relevant for land and many marine and coastal situations. A separate Chapter 7 is included to briefly introduce issues unique to marine environments. Marine spatial planning is an emerging field for law and policy, but a fast growing area of science and technology. While it is beyond the scope of this book to cover marine spatial planning in depth, it was considered important to introduce the subject as a critical piece for achieving sustainable development goals in coastal and small island states and for addressing land-sea connectivity. Hopefully, in-depth coverage of law and policy considerations for marine spatial planning may be possible in the near future.

Many international law and policy instruments (such as those highlighted through several tables in the book) promote, call for, or reinforce national efforts to modernize spatial planning systems. Such global law and policy advances, combined with and aided by advances in scientific knowledge, are now being joined by new remote sensing and observational technologies to provide baseline landscape/ seascape conditions and monitor change. This relatively recent convergence of international law, science, and technology facilitates as never before the efforts of countries to modernize their planning processes, develop spatial plans supported by real data, and monitor implementation in the context of sustainable development goals.

For social, economic, and environmental sustainability, policy makers, practitioners, and stakeholders in all relevant sectors and disciplines must work together to develop and effectively implement integrated planning processes and plans. This is becoming increasingly evident as we all experience and learn more about the limits and capacity constraints of the planet's ecological processes and ecosystem services for sustaining life as we know it. Toward that end, biodiversity conservation (in all its forms - species, ecosystems, evolutionary processes) and climate change adaptation and mitigation must be mainstreamed in planning policies, laws, and programmes at all levels. It is hoped this book helps advance this effort through its elaboration of many policy and law tools that could play a supportive role. 



\section{Introduction}

\section{Context}

This book explores emerging concepts, challenges, and policy and law tools for modernizing public sector spatial (or physical) planning to be more comprehensive, integrated, ecosystem-based, and long-range. Modernization is necessary to advance development that is sustainable economically, socially, and environmentally, and this must include attention to biodiversity loss and climate change.

Rapid changes are underway in landscapes, seascapes, and watersheds throughout the world as a result of growing urbanization, industrialization, globalization, human population expansion, migration, growing energy demand and economic reforms. Today, governments and societies are also facing extraordinary challenges from climate change, the impacts of which are affecting most communities in some way and causing international organizations and countries to redefine sustainable development goals and how to achieve them. These forces are already affecting quality of life in many parts of the world and prompting efforts to strengthen and update planning processes to better fit $21^{\text {st }}$ century needs (see, e.g., Tewdwr-Jones, et al, 2010). They are placing growing demands on our planet's physical space, accelerating environmental degradation and biodiversity loss, and challenging national and international efforts to achieve economic, social, and environmental sustainability.

Climate change has added a new urgency for spatial planning systems to modernize and be better integrated. As awareness of climate change and its causes and impacts has grown, decision-makers in both public and private sectors are beginning to rethink "business-as-usual" in their planning processes. Attention is turning to longer time horizons for planning, the relationship between built and natural environments, the multi-layered scale of planning, linkages and interactions between policies, and participation of all governance actors where they live, work, and play (see, e.g., Wilson and Piper, 2010). And there is growing appreciation of the limits of conventional land use planning to effectively address these needs.

Efforts to undertake more integrated spatial planning have accelerated in recent decades, especially in Europe; the concept is emerging there as part of generally accepted planning practice and also spreading beyond Europe (see, e.g., Stead \& Meijers, 2009; Twedwr-Jones et al., 2010). There is movement to modernize conventional planning processes to better advance international commitments and national goals including for biodiversity and climate change. This means taking stock of policies, laws, and programmes that may need to be added or strengthened to give sufficient authority and implementation capacity for effective integrated spatial planning across sectors and government levels.

It should also be recognized that building a more integrated public sector planning approach for geographic space involves a gradual process of policy and programme reform. Modernizing longstanding conventional planning processes and practice is difficult and challenging in many respects, including to mobilize support and collaboration across all affected sectors and stakeholders groups in a particular space or across a nation. Numerous policies, laws, programmes, and economic, political, and social interests at all government levels are touched by these reforms. Institutional and social learning will be essential. In some cases, institutional adjustments may be required. In addition, 
for many actors biodiversity and climate change are not well-understood; special attention will be needed to help translate and disseminate ongoing scientific information and build knowledge about threats, remedies, and adaptive options.

Some change should be expected in most planning systems to accommodate biodiversity and climate needs. However, current planning research has found little convergence so far on the threeway relationship of spatial planning, biodiversity and climate change. In the limited cases where connection is being considered, it is most commonly for a specific plot or issue, not an ecosystemwide approach (UNITAR, 2018). It is hoped that this book can begin to help inform planners, legal experts, public sector decision-makers, and practitioners about the variety of existing and new tools that may be considered to support planning processes and plans that are grounded in this threeway relationship and can effectively deliver on national and global sustainable development goals.

\section{Purpose and audience}

The purpose of this book is to examine the changing role and nature of public sector spatial planning and how a diverse array of policy and law tools may be useful to support efforts to modernize spatial planning systems for $21^{\text {st }}$ century needs and commitments. This modernization will need to respond, in particular, to two critical global challenges facing all countries: reversing biodiversity loss and building resilience to climate change. In many countries, national planning systems are already beginning to build more comprehensive and integrated planning processes for long-term sustainable management of their physical space. Some of the driving forces include efforts to advance sustainable development goals, reduce resource use conflicts, better accommodate growing populations, and ensure protection of life-supporting ecosystem services.

Responding to this trend, references to integrated spatial planning are widespread throughout recent planning and environmental literature, especially since the mid-2000s, as challenges of sustainability, climate change, and compliance with international environmental commitments have gained attention. But there little elaboration of the variety of existing and emerging law and policy tools that might be used or adapted to support such efforts and facilitate an orderly transition to more integrated spatial planning generating broad community support, and concrete results on the ground (Stead \& Meijers, 2009).

This book begins such an elaboration. It highlights some of the main driving forces behind national and regional efforts to begin to modernize public sector planning of their geographic space. It then explores a variety of law and policy tools, existing in some manner in most countries, that could be used to advance such public sector planning. In so doing, it aims to offer ideas and options for policy-makers, practitioners, and stakeholders at different planning levels and scales in response to changing needs and emerging goals, particularly regarding biodiversity and climate change. While national planning is only one part of a government's portfolio, this role is critically important for creating a broad participatory framework so that all members of society can contribute to the vision and direction of future development and investment in their country while safeguarding social values, a economic and environmental sustainability.

Special effort has been made to minimize the use of technical language and create an easy-to- read document for general and specialist use. It is anticipated that the book and its various key messages will be informative for a wide and diverse audience depending on the topic being discussed and interest of the reader. Of course, national and subnational policy-makers and technical agencies 
with planning responsibilities generically or by sector (land and marine) are key audiences overall. Within that group, the overarching focus on tools to integrate biodiversity and climate change into spatial planning should be especially informative for land use, conservation, environmental, and marine spatial planners. Practitioners and community leaders and organizations also should find useful the initial sections on historical context, how national planning began, and how advances in environmental thinking, governance, science and technology in recent decades now are reviving and newly defining planning features and processes for modern needs. Benefits and challenges associated with efforts to modernize integrated spatial planning with biodiversity and climate change are included mainly to aid those promoting and implementing integrated spatial planning initiatives.

The discussion and key messages on advances in international law relevant for integrated spatial planning will be of special interest to policy makers, legal experts, and senior staff working with compliance, particularly obligations under the CBD and UNFCCC. In many countries, international law and policy commitments are key tools for building political support and action to strengthen national policy, law, and institutions. In addition to the CBD and UNFCCC cluster of obligations and guidance, there are many other international policies, treaties and programmes related to biodiversity and climate change which trigger more integrated spatial planning. These many instruments are too numerous to discuss individually in this book. However, a summary table is provided on the major international instruments that either directly require supportive integrated planning or are linked in some manner to integrated planning to achieve their objectives.

Finally, the main substantive purpose of the book - to explore both cross-cutting and subjectspecific policy and law options -- will be of particular interest to advisors and analysts involved in reviewing and making recommendations on specific tools for strengthening or building integrated planning processes and plans that include biodiversity and climate change. Other audiences which may find this book useful, depending on their orientation and interest, include local government administrators, private sector planners and conservation supporters, community organizations, local non-governmental leaders of indigenous groups, Non-governmental organizations (NGOs), researchers, and the general public, as well as students and teachers.

\section{Scope and approach}

This book complements and builds on two earlier and interconnected IUCN environmental law publications: IUCN Guidelines for Protected Areas Legislation (2011) and Legal Aspects of Connectivity Conservation-A Concept Paper (2013).

Integrated spatial planning as used here refers generally to spatial (physical) planning that goes beyond conventional or single-purpose land-use or urban planning to be more comprehensive, integrated, and long-range. This includes taking into account mandates and impacts of other sectoral policies related to a country's or region's geographic space and use of its land/sea resources. The goal of integrated spatial planning as it is being reframed for modern needs is to plan future development and investment opportunities in a particular geographic jurisdiction considering all major policies relevant for or impacting that area and its people, and creating more even distribution of economic development than might otherwise occur by market forces alone.

The analyses reflected herein draws on two main sources of information. First, a broad-based literature review was undertaken on emerging experiences with integrated spatial planning from an academic as well as a practitioner point of view. This review put special emphasis on recent spatial 
planning peer-reviewed publications that included some attention to biodiversity or climate change. While much of the planning literature, especially from the 2000 s, focuses on spatial planning for landscapes, some key concepts such as integration seem to be arising and articulated particular in articles on marine spatial planning (e.g., integrated coastal and marine resource management). It is clear that many of the issues, challenges, and policy and law tools discussed in this book can be applied directly or adapted to either land and marine/coastal environments.

In addition, in recent years the body of journal articles on marine spatial planning has increased markedly, probably in response in large part to improved scientific knowledge about the role of the oceans in sustaining life-support systems and the inherent interface between terrestrial and marine environments and economies. Because marine spatial planning is increasingly being recognized as an essential and significant part of national planning for coastal states and small island states, recent marine planning literature also was reviewed and a short chapter included on unique features and emerging issues for planning in marine and coastal environments. Finally, the literature review also included recent publications specifically on conservation planning, including for connectivity and for climate change adaptation.

The volume of spatial planning literature has grown in recent years spurred on by such issues as sustainable development, growing globalization, improvements in science and technology, and climate change challenges especially with the land-sea interface. The extensive list of references at the end of this book reflects some of this rich body of research and practice particularly relevant to the theme of the book.

Second, as an additional source of background information, this book draws on and incorporates analyses from a prior project undertaken by the IUCN-ELC during the period 2014-2016 (herein noted as the 2016 ELC project). That project collected information on the institutional and legal frameworks for land use and spatial planning in 16 countries, focusing especially on biodiversity and climate change aspects (see list of countries in the foreword). The information and analyses were prepared by country legal experts following a common outline. Countries were selected both for the diversity of legal systems and geographic distribution. Unfortunately, because of limited resources and time, that research could not be finalized or updated. So it would not have been appropriate here to cite specific issues from those cases that may have since been resolved. Nevertheless, a global synthesis of that project also was prepared in draft and graciously made available as background for this publication. That analytical work provided valuable and still-relevant generic lessons and key messages that were drawn upon and incorporated in this book.

Finally, it is important to note that this book is not intended to provide formal legal guidelines, but rather to introduce the subject as an important emerging area for contemporary environmental law. Much additional specific research and documentation of principles and applications on the ground are needed before there can be a collective sense of agreed messages and techniques sufficient for formal guidelines. Bringing land and marine spatial planning into the fold of environmental law is a relatively new area of legal research and there is still much to learn for best practice guidelines. This is especially the case with law and policy guidance which must be sufficiently well-grounded and flexible to be adapted and applied in different legal systems within their own particular socio-ecological and political settings. Moreover, integrating spatial planning, biodiversity, and climate change will likely involve use of some existing tools as well as breaking new ground with new tools and processes yet to be developed. Thus, the aim here is to provide sufficient context and background to support efforts toward modernizing public sector planning, and then offer a diverse set of law and policy 
options with varying potential, depending on the country, to help strengthen spatial planning for $21^{\text {st }}$ century needs, including biodiversity conservation and climate change adaptation and mitigation.

\section{Organization}

The report is organized in eight chapters following this introduction, each starting with a substantive discussion followed by a few key messages relevant for that topic. The initial chapters provide background and conceptual elements underpinning modern spatial planning to help set the stage for the later chapters (namely Chapters 6 and 7) and the main focus of the book - elaborating law and policy tools and approaches that could be used to support modern spatial planning. Chapter 1 briefly reviews the historical development of public sector planning and the focus and operations of traditional planning systems. Chapter 2 explores developments in international law, science and technology, and governance in recent decades that reinforce the need for modernized planning systems if countries are to meet their obligations and sustainable development goals. Chapter 3 highlights core elements of modern integrated spatial planning as it is emerging to meet global challenges including biodiversity conservation and climate change, and that differentiate it from more conventional land use planning approaches. It elaborates especially the need for an ecosystem approach and incorporating conservation plans as an integral part of spatial planning. This broader approach generates a number of benefits for biodiversity, climate change, connectivity, and sustainable development overall which are discussed in Chapter 4.

Beyond chapter 4, the book shifts from underlying concepts and supporting developments to considerations directly related to law and policy tools to aid integrated planning and plan implementation. Chapter 5 enumerates main challenges facing governments as they build more comprehensive and integrated planning systems; many of these challenges are shared across terrestrial and marine environments as countries strive to achieve their sustainable development goals.

Chapter 6 turns to the many policy and law tools and associated considerations that can aid in responding to the challenges and needs of modern integrated planning systems. It begins with an table listing the many law and policy instruments available in most countries that could be tapped to support comprehensive and integrated spatial planning including biodiversity conservation and climate change. Chapter 6 continues by highlighting several guiding principles for policy and law, many of which emerge from the conceptual discussions of earlier chapters. They are offered as options for action since not every idea will be feasible or appropriate in different legal systems. Moreover, the options are formatted as bullets to provide a snapshot of the many possibilities without going into detail at this exploratory stage but to generate interest and provide an overview. The discussion of specific legal tools and options for action begins with elements that are cross-cutting (e.g., coordination, implementation), followed by legal tools that are more specific (e.g., zoning, incentives, voluntary conservation).

Chapter 7 provides an introduction to marine spatial planning and some of the unique issues and challenges for law and policy with planning in marine and coastal environments. While in-depth coverage of marine spatial planning is beyond the scope of this book, the topic is an essential part of the big spatial planning picture in coastal countries and small island states. Marine spatial planning is needed not only for addressing interconnections and conflicts between marine and terrestrial uses, but also for planning the use of ocean space to accommodate the special needs of marine biodiversity and special measures for adaptation and mitigation of climate change. 
Chapter 8 concludes with several key messages that flow from the topics addressed in the book. Because the overall objective of the project has been to analyse concepts and present considerations and options for supportive law and policy, virtually all messages in this concluding chapter have some relevance for law and policy.

\section{Key terms}

Some basic terms in the fields of biodiversity conservation, climate change and spatial planning are important to define here for how they are being used. The terms and their formal or working definitions offered below are mostly drawn from international conventions and programmes, with a few reproduced from the 2013 IUCN Law and Connectivity Conservation - Concept Paper noted above. For some terms, two definitions are offered from different international authorities to show the emphasis of each. As with conventional practice in most planning literature, the reader should understand the term 'land' to include 'marine' unless the context requires otherwise. From time to time, notations such as 'landscape/seascape' or 'land/sea' are added to remind the reader of the broad application of the point being made.

When updating policy and law instruments to incorporate biodiversity conservation, ecosystem resilience, and climate change in planning processes, the legal advisor should review international treaty and policy commitments relevant to the jurisdiction in case certain definitions are necessary or appropriate to incorporate in domestic legislation, either directly or by reference to the relevant treaty or policy. The list of terms below is illustrative, not exhaustive.

Adaptation (generally): The process of adjustment to actual or expected climate and its effects. In human systems, adaptation seeks to moderate or avoid harm or exploit beneficial opportunities. In some natural systems, human intervention may facilitate adjustment to expected climate and its effects. (IPCC 2014, Annex II - Glossary (pp. 117-130))

Adaptation in nature conservation: conservation action that increases the resilience of species and ecosystems to climate change and facilitates their adaptation (e.g., facilitating movement of species across the landscape to enable shifts in distributions, reducing other sources of harm known to interact with climate effects, conserving species genetic diversity to maximize chances of adaptation and maintain ecosystem services, creating or modifying habitat to reduce climate effects). (Doswald \& Osti, 2011, p. 5)

Adaptive capacity: The ability of systems, institutions, humans and other organisms to adjust to potential damage, to take advantage of opportunities, or to respond to consequences.

Biological diversity or biodiversity: the variability among living organisms from all sources including, among other things, terrestrial, marine and other aquatic ecosystems and the ecological complexes of which they are a part, and diversity within species, between species and of ecosystems (CBD, Art. 2). Monitoring the components of biodiversity requires several levels of organization: regional landscape/seascape, community-ecosystem, population-species, and genetic (Noss, 1990, in Lausche et al., 2013, p. 14).

Climate change: means a change of climate which is attributed directly or indirectly to human activity that alters the composition of the global atmosphere and which is in addition to natural climate variability observed over comparable time periods (Art. 1.2, UNFCCC). 
Climate Climate (IPCC 2014): in a narrow sense is usually defined as the average weather, or more rigorously, as the statistical description in terms of the mean and variability of relevant quantities over a period of time ranging from months to thousands or millions of years. The classical period for averaging these variables is 30 years, as defined by the World Meteorological Organization. The relevant quantities are most often surface variables such as temperature, precipitation and wind. Climate in a wider sense is the state, including a statistical description, of the climate system. (IPCC, 2014, Annex II - Glossary)

Climate change (IPCC continued): refers to a change in the state of the climate that can be identified (e.g., by using statistical tests) by changes in the mean and/or the variability of its properties and that persists for an extended period, typically decades or longer. Climate change may be due to natural internal processes or external forcings such as modulations of the solar cycles, volcanic eruptions and persistent anthropogenic changes in the composition of the atmosphere or in land use. Note that the Framework Convention on Climate Change (UNFCCC), in its Article 1, defines climate change as: 'a change of climate which is attributed directly or indirectly to human activity that alters the composition of the global atmosphere and which is in addition to natural climate variability observed over comparable time periods'. The UNFCCC thus makes a distinction between climate change attributable to human activities altering the atmospheric composition and climate variability attributable to natural causes. (IPCC, 2014, Annex II - Glossary)

Connectivity: a measure of the extent to which plants and animals can move between habitat patches, as well as the extent to which non-local ecosystem functions associated with soil and water processes, for example, are maintained (Worboys et al., 2010, ['Non-local ecosystem functions' relates to those larger-scale ecosystem functions and ecological processes at the landscape/seascape or sometimes even the regional or continental level on which the integrity of the local ecosystem functions depend.] Conservation measures to maintain species connectivity include maintenance or restoration of associated ecosystems and ecological processes in the broader landscapes/ seascapes/regions of which they are a part. (Lausche et al., 2013, p. 16)

Conservation: (as defined in the IUCN Guidelines for Protected Areas Management, 2008/2013) refers to the in-situ maintenance of ecosystems and natural and semi-natural habitats and of viable populations of species in their natural surroundings and, in the case of domesticated or cultivated species, in the surroundings where they have developed their distinctive properties. (Dudley, 2008, p. 9)

Ecological integrity: the condition of an ecosystem where the structure and function are unimpaired by human-caused stresses, and where the ecosystem, biological diversity and supporting processes are likely to persist (Worboys et al., 2010).

Ecological network: system of nature reserves and their interconnections that make a fragmented natural system coherent to support more biological diversity than in its non-connected form, composed of core areas (usually protected), buffer zones, and ecological linkages connecting these, and containing both natural and semi-natural landscape/seascape elements configured and managed to maintain or restore ecological functions as a means of conserving biodiversity while also providing opportunities for the sustainable use of natural resources; sometimes called 'conservation network' or 'connectivity network'. (adapted from Center for Large Landscape Conservation, 2011; Bennett, 2004, p. 6). 
Ecological processes: biological, physical, and chemical processes that sustain ecological systems and life as we know it. These processes include water flows and movement, nutrient recycling, sediment movement and predator-prey (food chain) relationships. Ecological processes are part of a functioning ecosystem and together with the physical conditions present (depth of water, soil type, temperature of air)) make up the ecological function of an area. Collectively, ecological processes produce organic matter using energy through photosynthesis and chemosynthesis, transfer carbon and nutrients through food webs and through decomposition, drive soil formation, and enable the production of organisms, for example, by pollination of plants by insects. Ecological processes influence the extent, distribution and biodiversity of systems. (Lausche et al., 2013, p. 15)

Ecological resilience: the capacity of a system to withstand changes to the processes that control its structures. As explained in the scientific literature, "[t]here is growing scientific understanding that disturbing ecosystems can reduce their resilience and result in dramatic shifts to less desirable states that weaken their capacity to provide ecosystem goods and services." This weakened state has financial implications. (Hilty et al., 2006, p. 9-10)

Ecosystem (CBD 1992 definition): a dynamic complex of plant, animal and micro-organism communities and their non-living environment, interacting as a functional unit (CBD, Art.2).

Ecosystem (IPCC 2014 definition): a functional unit consisting of living organisms, their non-living environment and the interactions within and between them. The components included in a given ecosystem and its spatial boundaries depend on the purpose for which the ecosystem is defined: in some cases they are relatively sharp, while in others they are diffuse. Ecosystem boundaries can change over time. Ecosystems are nested within other ecosystems and their scale can range from very small to the entire biosphere. In the current era, most ecosystems either contain people as key organisms, or are influenced by the effects of human activities in their environment. (IPCC, 2014, Annex II - Glossary)

Ecosystem approach: a primary framework for action under the CBD; as defined by the CBD, it is a strategy for the integrated management of land, water, and living resources that promotes biodiversity conservation and sustainable use in an equitable way; the application of the ecosystem approach will help to reach a balance of the three objectives of the Convention on Biological Diversity: conservation; sustainable use; and the fair and equitable sharing of the benefits arising out of the utilization of genetic resources (CBD COP V/6, para. 7A-1); it is based on the application of appropriate scientific methodologies focused on levels of biological organization which encompass the essential processes, functions and interactions among organisms and their environment. It recognizes that humans, with their cultural diversity, are an integral component of ecosystems. (https://www.cbd.int/ecosystem/).

Ecosystem-based approaches to adaptation: the use of biodiversity and ecosystem services as part of an overall adaptation strategy to help people adapt to the adverse effects of climate change (CBD 2009); and may include sustainable management, conservation and restoration of ecosystems, as part of an overall adaptation strategy that takes into account the multiple social, economic and cultural co-benefits for local communities. Adaptation is facilitated through both specific ecosystem management measures, (e.g., managed realignment) and through increasing ecosystem resilience to climate change (e.g., watershed management, conserving agricultural species' genetic diversity). (Doswald \& Osti, 2011, p. 5) 
Ecosystem-based approaches to mitigation: use of ecosystems for their carbon storage and sequestration service to aid climate change mitigation. Emissions reductions are achieved through creation, restoration and management of ecosystems (e.g., forest restoration, peat conservation, seagrass bed conservation). (Doswald \& Osti, 2011, p. 5)

Ecosystem restoration: the process of assisting the recovery of an ecosystem that has been degraded, damaged, or destroyed. (Metternicht, 2018, p. ix)

Ecosystem services (from IPCC): ecological processes or functions having monetary or non-monetary value to individuals or society at large. These are frequently classified as (1) supporting services such as productivity or biodiversity maintenance, (2) provisioning services such as food, fiber or fish, (3) regulating services such as climate regulation or carbon sequestration and (4) cultural services such as tourism or spiritual and aesthetic appreciation. (IPCC, 2014, Annex II - Glossary)

Ecosystem/ecological goods and services: the benefits arising from the ecological functions of healthy ecosystems that are essential to life of all living organisms (plants, animals, humans), and also provide social, cultural and economic value to humans. Examples of ecological goods include clean air and abundant fresh water. Examples of ecological services include purification of air and water, maintenance of biodiversity, decomposition of wastes, soil and vegetation generation and renewal, pollination of crops and natural vegetation, groundwater recharge, seed dispersal, greenhouse gas mitigation through carbon storage and aesthetically pleasing landscapes. (Lausche et al., 2013, p. 15)

Environmental impact assessment (EIA): an environmental impact assessment is normally a report generated through the process of evaluating the likely environmental impacts of a proposed project or development, taking into account inter-related socio-economic, cultural and human-health impacts, both beneficial and adverse; by using EIA both environmental and economic benefits can be achieved, such as reduced cost and time of project implementation and design, avoided treatment/clean-up costs and impacts of laws and regulations. (CBD guidance on Impact Assessment, at https://www.cbd.int/impact/whatis.shtml\#environmental).

Green or green-blue infrastructure: a strategic approach to land and water management that encompasses a wide array of specific practices and definitions. An EU workshop in 2011 on green infrastructure projects and policies defined the concept as an extension of the ecological network concept: green infrastructure is the network of natural/semi-natural areas, features and/or green spaces in rural and urban, terrestrial and coastal areas, which together enhance ecosystem health and resilience of species and ecosystems in adapting to climate change while securing multiple benefits for biodiversity conservation and humans and ensuring the provision of ecosystem services and goods (Ecology Institute, 2011).

Habitat: an area which provides the combination of resources (like food, cover, water) and environmental conditions (temperature, precipitation, presence or absence of predators and competitors) that promotes occupancy by individuals of a given species (or populations) and allows those individuals to survive and reproduce; the application of this definition becomes defined by the particular species involved. (Franklin et al., 2002, p. 21)

Habitat fragmentation: the reduction and isolation of patches of natural environment, including landscape/seascape transformations that break large habitat into smaller pieces; the concept ultimately applies to the species level because habitat is defined with reference to a 
particular species. Fragmentation can come about naturally (for example, through fire, storms, or flooding) or by human actions (Franklin et al., 2002, in Lausche et al., 2013, p. 15).

Integrated assessment: A method of analysis that combines results and models from the physical, biological, economic and social sciences and the interactions among these components in a consistent framework to evaluate the status and the consequences of environmental change and the policy responses to it. (IPCC, 2014, Annex II - Glossary)

Integrated Coastal Zone Management (ICZM): an integrated approach for sustainably managing coastal areas, taking into account all coastal habitats and uses. (IPCC, 2014, Annex II - Glossary)

Marine spatial planning: an area-based management strategy with a public process of analyzing, planning, and allocating the spatial and temporal distribution of human activities in marine areas to achieve certain ecological, economic and social objectives that are usually specified through a political process (Ehler \& Douvere, 2009, and MEAN, 2011) The broad goal is to achieve the well-being and long-term sustainability of ocean ecosystems in order to maintain essential ecosystem services for human populations (Foley et al., 2010, in Lausche et al., 2013, p. 154).

Mitigation (of climate change): a human intervention to reduce the sources or enhance the sinks of greenhouse gases (GHGs). Also human interventions to reduce the sources of other substances which may contribute directly or indirectly to limiting climate change, including, for example, the reduction of particulate matter emissions that can directly alter the radiation balance (e.g., black carbon) or measures that control emissions of carbon monoxide, nitrogen oxides, Volatile Organic Compounds and other pollutants that can alter the concentration of tropospheric ozone which has an indirect effect on the climate. (IPCC, 2014, Annex II - Glossary)

National - where appropriate to the context, includes subnational when provinces or states have independent authority to enact certain law and policy instruments related to spatial planning.

Ocean zoning: an area based marine management strategy that is related to marine spatial planning which produces a broad plan for ocean uses, with ocean zoning giving effect to that plan through regulatory tools. (Lausche et al., 2013, p. 154)

Remote sensing: simply the observation or measurement of data from a distance.

Resilience: the capacity of social, economic and environmental systems to cope with a hazardous event or trend or disturbance, responding or reorganizing in ways that maintain their essential function, identity and structure, while also maintaining the capacity for adaptation, learning and transformation. (IPCC, 2014, Annex II - Glossary)

Risk: the potential for consequences where something of value is at stake and where the outcome is uncertain, recognizing the diversity of values. Risk is often represented as probability or likelihood of occurrence of hazardous events or trends multiplied by the impacts if these events or trends occur. In this report, the term risk is often used to refer to the potential, when the outcome is uncertain, for adverse consequences on lives, livelihoods, health, ecosystems and species, economic, social and cultural assets, services (including environmental services) and infrastructure. (IPCC, 2014, Annex II - Glossary) 
Strategic Environmental Assessment (SEA): numerous definitions have evolved; generally SEA is understood as the formalized, systematic and comprehensive process of identifying and evaluating the environmental consequences of proposed policies, plans or programmes to ensure that they are fully included and appropriately addressed the earliest possible stage of decision-making on a par with economic and social considerations. (CBD guidance in impact assessments, at: https://www.cbd.int/impact/whatis.shtml\#environmental)

Sustainable use: Sustainable use means the use of components of biological diversity in a way and at a rate that does not lead to the long-term decline of biological diversity, thereby maintaining its potential to meet the needs and aspirations of present and future generations. (CBD, article 2)

Sustainability: a dynamic process that guarantees the persistence of natural and human systems in an equitable manner. (IPCC, 2014, Annex II - Glossary)

Sustainable development: development that meets the needs of the present without compromising the ability of future generations to meet their own needs (WCED, 1987).

Uncertainty: a state of incomplete knowledge that can result from a lack of information or from disagreement about what is known or even knowable. It may have many types of sources, from imprecision in the data to ambiguously defined concepts or terminology, or uncertain projections of human behaviour. Uncertainty can therefore be represented by quantitative measures (e.g., a probability density function) or by qualitative statements (e.g., reflecting the judgment of a team of experts). (IPCC, 2014, Annex II - Glossary)

Vulnerability: the propensity or predisposition to be adversely affected. Vulnerability encompasses a variety of concepts and elements including sensitivity or susceptibility to harm and lack of capacity to cope and adapt. (IPCC, 2014, Annex II - Glossary) 


\section{Setting the stage}

This chapter highlights stages of the historic development of conventional land use/urban in different regions and how the need emerged. Most approaches were relatively problem or issue specific, in part because the need for more comprehensive planning had not yet arisen. Also, such global environmental concerns as biodiversity and climate change had not yet emerged.

\subsection{Historic perspective}

National public sector planning had different beginnings in different countries depending on the local political, geographic, and socio-economic circumstances that created the need. It is instructive to briefly highlight how some of the early planning policies and programmes in different regions were triggered and progressed, particularly for planners or other experts working to define planning frameworks in countries just starting the effort. Planning literature is relatively in agreement that western Europe led the way in early national land use and urban planning initiatives through various distinct planning policies and laws. (See Alternam, 2001, for a comparative analysis of historical beginnings for national planning in 10 democratic, advanced-economy countries). Today, Europe continues to generate the bulk of recent literature on spatial planning experience and its evolution to address modern problems, with Australian writers also quite active (see, e.g., Stead, 2012; Stead \& Meijers, 2009; Vettoretto, 2009; Kukala, 2017; Wilson \& Piper, 2008; Metternicht, 2018).

By the mid-1900s, various forms of land use planning were emerging in most industrialized countries. In the West, government-led planning efforts immediately following World War II were hindered as people associated the topic with communism and central planning. In those initial post-war years, researchers of urban and regional planning tended to avoid the topic. Gradually, however, public support for planning began to grow as rapid industrialization, urbanization and a concern for overexploitation of natural resources led to some national planning intervention in areas generating most immediate public concern - mainly housing, expanding settlements out from central cities, and basic infrastructure. Gradually, specialized planning policies also were enacted in some countries to address special environmental concerns such as wildlife protection, wetlands and watershed conservation, and protected areas'.

The form and focus of early planning in the developed economies depended on the political priorities and socio-economic needs of the time. Reasons for policy-makers to support national or sector planning varied widely. It could be used as a tool for nation building, to reduce inter-regional disparities, in response to the territorial policies of the European Union (EU) (for EU members), for environmental and infrastructure goals, to accommodate growth and development pressures, or in response to crises. For example, in the Netherlands, as part of nation-building, planning became essential for public management of water in the lowlands and land reclamation. In the UK, growth management especially through housing and sanitation was key. In Germany, nation-building and national unification were an important trigger. In France and Japan, it was reducing inter-regional disparities. In Israel, it was population distribution towards nation-building. (Alterman 2001)

In countries with colonial histories, colonial powers determined how much national or local planning occurred in its colonies and national governments inherited the colonial planning instruments. Planning was both urban and regional (related to the spatial distribution of development projects). These 
approaches commonly took precedent over the indigenous and traditional planning approaches that had evolved over centuries to build settlements, trading networks, and imperial cities based on pre-colonial cultural, economic, and local value systems (Okeke, 2015).

Urban design in Anglophone Africa was commonly imported from British town planning laws, namely the Town and Country Planning Act of 1947. These focused originally on sanitation and housing for cities, towns, and lands being developed (Cullingworth \& Nadin, 2006, pp. 16-17). In Francophone Africa colonial authorities prepared planning instruments on site given local conditions and focused on economic development planning and building colonial towns for trading purposes. Both approaches took precedent over traditional urban designs and spatial planning patterns that had evolved over centuries based on pre-colonial cultural, economic, and local value systems; both systems were grounded in numerous legislative provisions (Okeke, 2015).

According to research on urban planning in African cities, legally-binding master planning prevailed in the 1930s-1960s, but was out of favor by the 1970s as the now-independent countries found them not sufficiently in line with traditional practices, too restrictive and exclusionary (Okeke, 2015, p. 9). Since the 1990s, Africa has been in an action planning phase and faces challenges today to stabilize its urban system and undertake territorial planning with policy reforms that re-instate the more traditional notion of green planning for sustainable urbanism and development that have less interference with nature (Okeke, 2015).

In the case of South Africa, the history of planning is especially complex, shaped over time by different legal systems for planning, including that of the traditional peoples, Dutch and English through colonization. The draft case study from the 2014 ELC project explained that arrival of the Dutch colonialists in 1652 brought basic planning for what became Cape Town. This included land surveying to establish street grid patterns and demarcate settlements. In 1795, the English conquered the Cape and introduced a new planning mechanism, the restrictive covenant, to restrict certain types of land use as settlements grew and land use competition emerged. This tool was later integrated into the planning legislation to emerge with the creation of the Union of South Africa in 1909.

Other political forces shaping South Africa's present-day spatial planning system included the apartheid era where, for example, the Native Land Act 1913 was the first national legislative attempt to introduce racial land segregation. The post-apartheid era in the 1990 s provided the transition to a constitutional democracy and transformation of the land use planning regime. The new constitution of 1996 elaborated a diverse array of rights, and legislation was also prescribed forregional planning, urban and rural development, provincial planning, municipal planning and cooperative governance.

South American countries also experienced colonialism. These occupations frequently did not transfer planning systems to any significant degree. Most of the countries were relatively sparsely populated. In South America, processes related to land reform were important for land use planning. It took some time after independence and land reform for most countries to formalize land use planning within their legal and institutional systems.

Argentina offers an example from the ELC study. It was occupied by Spain in 1580 and for almost three centuries various development models were tried, all focused on building an export-based economy with basic produce. With independence from Spain in 1816, efforts continued to develop an export-based economy, but several domestic socio-economic crises after World War II stymied efforts to strengthen national administrative systems, and formal land use plans, either urban or rural, 
were not a priority. Historically, integrated spatial planning in Argentina was not a major concern of national or provincial governments, although policies and actions impacted urban development significantly (Monkkonen \& Ronconi, 2013). It was not until 2002, as environmental protection became a major concern, that general environmental legislation was enacted to include specific regulations for environmental law use planning and EIA. Environmental laws began to be enacted in the late 2000 s to protect specific ecosystems such as native forests and glaziers.

To close this historic sampling of early planning processes and their evolution, in the 1970s and 1980s, many countries were confronted with increasing and sometimes conflicting rural land use pressures from specialization, agricultural intensification, resource degradation, and the new wave of support for nature conservation. The response was to broaden the scale of planning to include rural areas facing growth pressures and coastal zones in similar straits. In the 1990s, as international policies broadened to issues of quality of life, equity, and sustainability, spatial planning began to be seen as a tool, among a basket of tools, to rationalize land/marine use conflicts, promote social participation, and integrate economic development sectors and their ecological components for long-term planning. This meant better understanding values and spatial measures to protect basic ecosystem services, biodiversity, and climate change adaptation. (Metternicht, 2017)

\subsection{Many labels used}

Public sector planning of space and place has taken on different names over the years, depending on tradition and emphasis. A 2017 United Nations Global Land Outlook working paper on land use planning found several variations in names used in different countries. The purpose of that paper was to analyse land use planning elements for sustainable land use, a concept defined to mean "the use of components of biological diversity in a way, and at a rate, that does not lead to the longterm decline of biological diversity" (Metternicht, 2017). That paper observed that since the 1990s, sustainable development as a planning concept and national goal has gained support from donor and development agencies and this has included assistance in funding a variety of national plans and policies related to natural resources management, use, protection and conservation - all spatial elements.

Collectively, many of these efforts directly or indirectly support biodiversity conservation, climate change adaptation, building ecosystem resilience, and spatial planning in some form. However, many are prepared by different agencies in different sectors under different mandates and timeframes. There may be fragmentation of issues and implementation, gaps, and inconsistencies. A next step for such situations will be to undertake the critical and difficult challenge of integrating these many planning instruments into a comprehensive spatial planning framework that can be harmonized across sectors and legal instruments. See Table 1.1 for some examples of planning labels with spatial content. While these labels are mostly land-oriented, application commonly included coastal and at least near-shore marine areas in coastal countries. 


\section{Table 1.1 Sampling of different planning labels with spatial elements for land or} resources

\begin{tabular}{|c|c|}
\hline Name & Definition/purpose \\
\hline $\begin{array}{l}\text { 1. Land use } \\
\text { planning }\end{array}$ & $\begin{array}{l}\text { The systematic assessment of land and water potential, alternatives for land use and } \\
\text { economic and social conditions, in order to select and adopt the best land use op- } \\
\text { tions. Its purpose is to select and put into practice those land uses that will best meet } \\
\text { the needs of the people while safeguarding resources for the future. This includes } \\
\text { coastal areas. }\end{array}$ \\
\hline $\begin{array}{l}\text { 2. Integrated land } \\
\text { use planning }\end{array}$ & $\begin{array}{l}\text { Assesses and assigns the use of resources, taking into account different uses, and } \\
\text { demands from different users, including all agricultural sectors - pastoral, crop and } \\
\text { forests - as well as fisheries, tourism, industry and other interested parties. }\end{array}$ \\
\hline $\begin{array}{l}\text { 3. Participatory } \\
\text { land use } \\
\text { planning }\end{array}$ & $\begin{array}{l}\text { Used for planning of communal or common property land, important in many commu- } \\
\text { nities where communal lands are the most seriously degraded, and where conflicts } \\
\text { over land/marine use rights exist. Arrangements can be regulated through negoti- } \\
\text { ation among stakeholders, and communally binding rules for sustainable resource } \\
\text { management based on planning units, social units (e.g., village) or geographical units } \\
\text { (e.g., watershed) can be adopted. People-centered, bottom-up approach recognizing } \\
\text { differences that exist from place to place, with respect to socio-cultural, economic, } \\
\text { technological and environmental conditions. }\end{array}$ \\
\hline $\begin{array}{l}\text { 4. Ecological or } \\
\text { environmental } \\
\text { land/marine } \\
\text { use planning }\end{array}$ & $\begin{array}{l}\text { An environmental policy instrument to regulate land/marine use and productive ac- } \\
\text { tivities, to protect the environment, promote the conservation and sustainable use } \\
\text { of natural resources, considering land/marine use potential and land/marine degra- } \\
\text { dation trends. It is considered by some to be the most appropriate policy instrument } \\
\text { to harmonize human activities and environmental sustainability in the short, medium } \\
\text { and long term. }\end{array}$ \\
\hline $\begin{array}{l}\text { 5. Marin } \\
\text { plans }\end{array}$ & $\begin{array}{l}\text { Coastal and marine spatial plans-or marine plans-is a science-based tool that re- } \\
\text { gions can use to address specific ocean management challenges and advance their } \\
\text { goals for economic development and conservation. Government agencies use marine } \\
\text { planning to coordinate activities among all coastal and ocean interests and provide the } \\
\text { opportunity to share information. This process is designed to decrease user conflict, } \\
\text { improve planning and regulatory efficiencies, decrease associated costs and delays, } \\
\text { engage affected communities and stakeholders, and preserve critical ecosystem } \\
\text { functions and services. Marine planning is a process developed from the bottom up to } \\
\text { improve collaboration and coordination among all coastal and ocean interests, and to } \\
\text { better inform and guide decision-making that affects their economic, environmental, } \\
\text { security, and social/cultural interests. (https://cmsp.noaa.gov) }\end{array}$ \\
\hline $\begin{array}{l}\text { 6. National } \\
\text { adaptation } \\
\text { plans } \\
\text { (UNFCCC) }\end{array}$ & $\begin{array}{l}\text { The national adaptation plan (NAP) process of the UNFCCC Cancun Adaptation } \\
\text { Framework (CAF), initiated in 2010; Parties are to formulate and implement national } \\
\text { adaptation plans (NAPs) as a means of identifying medium- and long-term adaptation } \\
\text { needs and developing and implementing strategies and programmes to address those } \\
\text { needs. It is a continuous, progressive and iterative process which follows a coun- } \\
\text { try-driven, participatory and fully transparent approach. }\end{array}$ \\
\hline $\begin{array}{l}\text { 7. National forest } \\
\text { plans (to the } \\
\text { UN Forest } \\
\text { Forum) }\end{array}$ & $\begin{array}{l}\text { Voluntary reports designed to be useful planning tools to help countries assess their } \\
\text { progress in implementing proposals for action, analyze lessons learned, identify gaps } \\
\text { and obstacles that the country might wish to address, and catalyze enhanced coop- } \\
\text { eration and coordination on forests among government agencies and other stakehold- } \\
\text { ers in the country. The reports are intended to help identify actions that may be taken } \\
\text { at regional and international levels, including by UNFF, to facilitate countries' efforts to } \\
\text { achieve sustainable forest management. }\end{array}$ \\
\hline $\begin{array}{l}\text { 8. Protected area } \\
\text { system plans }\end{array}$ & $\begin{array}{l}\text { Plans for design of a total reserve system covering the full range of ecosystems and } \\
\text { species communities, identifying the range of purposes of the protected areas and } \\
\text { the relationships among them (i.e. formal protected areas, other conservation areas, } \\
\text { connectivity needs, other relevant land uses). Should include governance }\end{array}$ \\
\hline
\end{tabular}




\begin{tabular}{|c|c|}
\hline Name & Definition/purpose \\
\hline & $\begin{array}{l}\text { information on how various stakeholders and communities can interact and partici- } \\
\text { pate to support effective governance and sustainable management of the protected } \\
\text { areas system and individual sites. (IUCN) }\end{array}$ \\
\hline $\begin{array}{l}\text { 9. National } \\
\text { fisheries } \\
\text { management } \\
\text { plans }\end{array}$ & $\begin{array}{l}\text { A formal or informal arrangement between a fishery management authority and stake- } \\
\text { holders (interested parties), identifying the background to the fishery, including all } \\
\text { major stakeholders, agreed objectives (covering the economic, social and ecological } \\
\text { components for the fishery) and specific rules and regulations that apply. }\end{array}$ \\
\hline $\begin{array}{l}\text { 10. National } \\
\text { biodiversity } \\
\text { strategy and } \\
\text { action plans } \\
\text { (NBSAP) }\end{array}$ & $\begin{array}{l}\text { Pursuant to Aichi Biodiversity Target } 17 \text {, adopted } 2010 \text { at the } 10^{\text {th }} \text { COP of CBD. Con- } \\
\text { sidered the principal instruments for implementing the Convention at the national level } \\
\text { (Article 6). Requires countries to prepare a national biodiversity strategy (or equivalent } \\
\text { instrument) and to ensure that this strategy is mainstreamed into the planning and } \\
\text { activities of all those sectors whose activities can have an impact (positive and neg- } \\
\text { ative) on biodiversity. Defines current status of biodiversity, the threats leading to its } \\
\text { degradation and the strategies and priority actions to ensure its conservation and sus- } \\
\text { tainable use within the framework of the socio-economic development of the country. }\end{array}$ \\
\hline $\begin{array}{l}\text { 11. National } \\
\text { environmental } \\
\text { action plans } \\
\text { (NEAP) }\end{array}$ & $\begin{array}{l}\text { In furtherance of the Millennium Development Goal } 7 \text { (2014), manage natural resourc- } \\
\text { es and ecosystems sustainably (including biodiversity and environmental resources), } \\
\text { many countries prepared National Environmental Action Plans integrating national } \\
\text { policies and programmes to ensure environmental sustainability. NBSAPs are more } \\
\text { recent; and it is intended that NBSAP results be integrated into other national devel- } \\
\text { opment and environment plans. }\end{array}$ \\
\hline $\begin{array}{l}\text { 12. Con } \\
\text { plan }\end{array}$ & $\begin{array}{l}\text { Spatial planning instruments incorporating current and future conservation needs to } \\
\text { achieve conservation and management objectives of particular areas and natural fea- } \\
\text { tures based on their conservation values needing protection, including ecosystem } \\
\text { functions, species and their habitat, evolutionary processes and connectivity con- } \\
\text { servation needs. }\end{array}$ \\
\hline $\begin{array}{l}\text { 13. Int } \\
\text { co } \\
\text { ma } \\
\text { pla }\end{array}$ & $\begin{array}{l}\text { Combines two approaches to water planning: integrated water resources manage- } \\
\text { ment and integrated coastal zone management. This is a planning process to link } \\
\text { management activities of the river basin and the coastal zone where needed - when } \\
\text { development or natural disasters in freshwater systems have negative impacts on the } \\
\text { oceans or vice versa. }\end{array}$ \\
\hline $\begin{array}{l}\text { 14. National } \\
\text { integrated } \\
\text { development } \\
\text { plans }\end{array}$ & $\begin{array}{l}\text { National plans that integrate development needs and goals into each stage of the } \\
\text { national planning cycle. The national planning process is comprised of all the activ- } \\
\text { ities and decisions undertaken at national, subnational and sector level by diverse } \\
\text { stakeholders to both develop and implement policies, strategies, plans and projects. } \\
\text { (UNDP, 2016) }\end{array}$ \\
\hline $\begin{array}{l}\text { 15. Strategic } \\
\text { Environmental } \\
\text { Assessments of } \\
\text { land use plans } \\
\text { (SEA) }\end{array}$ & $\begin{array}{l}\text { Proposed and existing land use plans may be subject to an SEA. This represents } \\
\text { another way of integrating conservation considerations into land use planning pro- } \\
\text { cesses. In the EU, for example, a Directive on environmental assessment (Directive } \\
2001 / 42 / E C \text { ) states that town and country planning decisions, among others, that set } \\
\text { the framework for future development consent for projects listed in the Directive have } \\
\text { to be made subject to an SEA (see Lausche et al., 2013). }\end{array}$ \\
\hline
\end{tabular}

(Items 1-4 adapted from Metternicht, 2017). 


\subsection{Common features of conventional land use/urban planning}

Planning and conservation literature highlight several common characteristics of many conventional land use/urban planning systems that limit their ability to integrate biodiversity and climate change needs. Similar findings came from several of the draft case studies of the 2014 ELC integrated planning project. The list below reflects some of the main issues identified by both sources that may limit capacity for comprehensive, integrated spatial planning with biodiversity and climate change:

- Principally focused on urban planning, less on rural or village planning

- Mostly land-based, less attention to marine or land/marine interface in coastal countries

- Lack of holistic approach integrated across sectors

- Short term planning horizon

- Multiple institutions with separate and sometimes overlapping responsibilities, excessive bureaucracy

- No mechanism for systematic coordination horizontally or vertically

- Weak capacity

- Conservation plans and connectivity needs may not be incorporated

- Stakeholder participation and consultation may be limited

- Plans may not be legally binding; if legally binding, may have uneven enforcement

- Governance predominantly top-down, although local participation is growing as local communities, indigenous and traditional peoples gain voice

- Implementation gaps; issues of capacity, resources, consistency, political factors, and monitoring.

\subsection{Influence of the concept of 'sustainable development'}

To appreciate one of the most powerful driving forces behind efforts to modernize planning processes, it is worth turning to the idea of 'sustainable development'. Through the 1990s and 2000s, unguided economic development and growth, plus other global challenges noted above, continued to generate negative social and environmental impacts for many communities. This drew attention to the concept of sustainable development, how it could guide development, and what specific goals and targets it could embrace. The concept of 'sustainable development had its global launch with Our Common Future, the 1987 report of the World Commission on Environment and Development (Bruntland Commission).

The concept gradually gained momentum as a policy goal, though admittedly nebulous and confusing to apply on the ground. It was picked up in international environmental treaties and policy, including those requiring plans and, among other things, countries began to incorporate 'sustainable development' as an explicit goal in domestic planning policies. Guidance on sustainable development emerged as a three-part concept: economic, social, and environmental sustainability. The Bruntland Commission concept has survived and proliferated in subsequent years. One elaboration in a recent environmental and land use planning text book explains sustainable development this way:

“...the paths of economic, social, environmental and political progress that aim to meet the needs of today without compromising the ability of future generations to meet their needs. Sustainable development aims to provide for the social and economic needs of society, while protecting environmental resources and values for the future." (Randolph, 2004) 
The use of the term 'sustainable development' today continues to expand and be part of goal-setting and policy at virtually all levels of governance. The concept has been universally validated through international endorsements such as the UN Millennium Declaration of 2000 (Resolution 55/2) and the Millennium Ecosystem Assessment, as well as other UN documents. In 2015 countries agreed and made commitments to support 17 UN Sustainable Development Goals (SDGs) 2015-2030. These goals include references to integrated planning as a tool for advancing sustainable development (see Table 2.3 in Chapter 2 below on SDG planning elements). The ever-expanding use of the concept has helped energize efforts to find ways that conventional land use/urban planning approaches can be modernized to be a more comprehensive and holistic framework for government planning to advance environmental as well as economic and social goals.

\subsection{Influence of environmental thinking and climate change}

Another significant force influencing the push for more integrated spatial planning with an environmental dimension has been the evolution of environmental thinking over the years (for a detailed discussion of this factor, see, e.g., Randolph, 2004). Environmental activism has roughly paralleled advances in scientific understanding about natural processes and the interdependence of human life and nature. Beginning in the late $19^{\text {th }}$ and into the $20^{\text {th }}$ centuries, the principal focus was on nature conservation which translated into preserving wild lands and cultural sites, mainly through parks, refuges, and other protected areas. After World War II, the focus broadened to concerns over public and environmental health as people witnessed firsthand major pollution problems and environmental damage, both from chemicals such as Dichlorodiphenyltrichloroethane (DDT) and human waste, that were backed up by science. Modern environmental health and pollution control laws were enacted in the 1970s and 1980s in many countries.

Today, as science and technology have continued to advance, the focus has expanded again to safeguarding ecological processes essential for life and the need for ecosystem-based management - goals that are fundamentally spatial. As an extension of the two prior phases, this third stage of environmental thinking with the emphasis on ecology and ecosystems requires greater integration of human needs and use of natural resources with the long-term protection of natural systems and the biodiversity and ecosystem services they provide.

Adding to this more system-based environmental focus, some writers propose that in the 2000s the emergence of climate change concerns became a significant and immediate trigger for broadening the spatial planning concepts to include adaptation. As knowledge has continued to improve about climate change causes and impacts, real impacts are already being felt, in some cases with serious devastation of human and natural environments (Wilson \& Piper, 2010). This also has added momentum to the need to modernize conventional planning processes with new methods and skills to deal with such impacts in a planning mode and incorporate adaptive measures in particularly threatened areas to build resilience for both built environments and natural environments.

Research confirms that climate change has already induced range shifts for many species as they seek their suitable climate space and more major shifts are projected (Wilson \& Piper, 2010). In general terms, the impact of climate change upon biodiversity habitat is to move it to higher altitudes and latitudes in response to warming. Specific adaptation potential will depend on the species as well as the spatial traits, habitat fragmentation, and other physical characteristics of available sites (e.g., water and soils). 
While literature covering aspects of climate change and spatial planning is growing, it is difficult to find analyses of the three-way relationship of spatial planning, climate change, and biodiversity. A 2008 study from northern Europe examined the scope of spatial plans in addressing the impact of climate change and found little linkage to biodiversity. At the same time a 2010 book on spatial planning and climate change by the same authors (a former planning practitioner and a natural resources manager) found that significant progress had been made in the 2000s beginning to move these issues forward, raising profound issues for the scale of planning and calling for new skills among planners and those doing environmental assessment. They conclude that the scope and direction of policy will continue to respond to this three-way relationship as the sciences of climate change and biodiversity make further advances in understanding impacts and adaptation needs (Wilson \& Piper, 2010).

\subsection{Common features of modern spatial planning}

There is a growing body of academic and practitioner literature on modern spatial planning and the main features that distinguish this approach from the more conventional and limited land use/urban planning. Considered by a many experts to have evolved from traditional continental European planning, integrated spatial planning is now being seen as a more strategic, sustainable, and responsive planning approach to development (Allmendinger \& Haughton, 2009). Increasingly, the term also can be found in relation to non-European contexts (Allmendinger \& Haughton, 2010; Wilson \& Piper, 2010). According to Wilson \& Piper in their 2010 book on spatial planning and climate change, modern spatial planning has four principal dimensions: I) an emphasis on long-term strategic thinking, 2) a mechanism for joined-up policy making, 3) a central role in moving towards sustainable development, and 4) an emphasis on inclusivity.

These dimensions can be translated into concrete features for modern spatial planning. The points below are drawn from the literature, the two complementary IUCN law reports noted at the beginning, and the draft global synthesis report of the 2014 ELC study. Several of these are elaborated in Chapter 6 on policy and law. Main features that differentiate modern spatial planning from more conventional land use/urban planning include the following:

a) sustainable development as the overarching goal for plan preparation, integration, implementation, and evaluation, balancing social, economic, and environmental needs for more even distribution of development benefits across a given space.

b) commitments under international law and policy (global, regional, supranational, bilateral) are important pillars for guiding spatial planning processes and resulting plans and complying with international obligations.

c) planning scale to include global as well as national, local, and individual actions; particularly the unprecedented nature of the climate change crisis raises profound questions for the scale of planning.

d) planning horizon to cover longer time-frame, beyond near-term (the focus of most conventional planning), to medium term (e.g., 30-50 years) for needs of near-future generations, and particularly the distant future (e.g., up to 75 or 100 years), to anticipate and be strategic about long-term planning needs for global change, particularly climate change, especially for development investments justified on the basis of an operational life of 75-100 years, such as hospitals, stadiums, interstate highways, airports, convention centers, etc. 
e) policy integration and coordination as an integral part of the process of preparation and implementation, with all levels of government and relevant sectors at all levels (discussed more in Chapter 6).

f) broad participation by all interested groups, stakeholders, and the public in preparation of spatial plans at national, regional, or local levels, as relevant to each level, and with implementation, monitoring, and evaluation.

(Several of these points are elaborated in the 2010 book, Spatial Planning and Climate Change, by Wilson \& Piper, which includes a lengthy chapter on 'Biodiversity and Climate Change'.)

\subsection{Key messages}

The history of public sector planning varies from country to country, and by region, depending on political context and issues that arose needing planning attention the time. Early efforts focused mostly on urban planning for health and safety, gradually broadened to areas around the cities experiencing sprawl, and subsequently to rural areas experiencing conflicts over use. Through the 1990s and 2000s, unguided economic development and growth plus other global challenges led to negative social and environmental impacts and the emergence in international policy of the concept of sustainable development defined to embrace social, economic and environmental sustainability. Integrated spatial planning became a tool to help advance the goals of sustainable development. That international movement plus growing environmental awareness about natural resource degradation, pollution, and climate change gave impetus for countries to begin efforts to modernize planning systems to better meet $21^{\text {st }}$ century needs. European countries led the way. 


\section{Advances in international law, science, and governance}

The impetus for modernizing public sector planning systems has been guided and fortified by advances in law, science and many aspects of governance in recent decades. This chapter reviews some of the significant developments in international environmental law, science and technology, and governance, especially since the 1990s, which are shaping modern spatial planning and associated policy and law. Many national land use planning systems, policies and laws were put in place decades ago. Updating and strengthening these systems has been guided by new international commitments, scientific advances, and broadened governance principles.

\subsection{International law and policy}

Spatial planning laws and policies are commonly the domain of national or subnational governments. International law and policy (including multi-country and bilateral agreements) may set out obligations and policy commitments that need incorporation in a national spatial planning system to ensure compliance.

International environmental law has made major strides especially since the 1990s. Global environmental awareness has grown about ecosystem functions, sustainability limits, and interdependencies between natural systems and human life. As it became increasingly clear that use of the Earth's natural resources was not sustainable at the current pace, sustainable development became a driving concept for planning. This was translated to mean not only economic sustainability but also environmental and social sustainability. Various national planning efforts now needed also to respond to international reporting and planning requirements under the new international law and policy instruments, for example, on national sustainable development goals, biodiversity conservation, and climate change adaptation and mitigation.

\subsubsection{International law instruments - CBD and UNFCCC}

Today there are more than 600 global and regional treaties dealing with environmental and conservation subjects of which 169 are global (see ECOLEX, the comprehensive online database of environmental law operated jointly by the Food and Agriculture Organization of the United Nations (FAO), IUCN and UN Environment, at https://www.ecolex.org). A number of these treaties contain specific obligations for actions that need to be reflected in national planning processes and plans.

In the 1990s, heads of state and international organizations made major advances in international environmental policy and law. This was in response to confirmed scientific evidence about accelerated biodiversity loss, degradation of ecosystems and basic ecosystem services, and impacts of climate change. Two global treaties emerged: the Convention on Biological Diversity (CBD) and the UN Framework Convention on Climate Change (UNFCCC), as major instruments with implications for national spatial planning. These two conventions and subsequent decisions of their respective Conferences of the Parties, reflected global concerns and proposed solutions for advancing sustainable development.

These two international law instruments, in particular, are helping guide and motivate countries to modernize their spatial planning systems to better address spatial needs for restoring and sustaining 
biodiversity, climate change adaptation, and related socio-ecological connections over the longterm. The CBD Strategic Plan for Biodiversity 2011-2020 and its accompanying Aichi Targets for Biodiversity have mandates and commitments that require spatial planning actions, both to support biodiversity and respond to climate change. Similarly, the 2015 Paris Agreement under the UNFCCC (which entered into force in 2016) sets out new targets for carbon emissions, and emphasizes the importance of ensuring integrity of all ecosystems, including oceans, and the ability to adapt to the adverse impacts of climate change as well as foster climate resilience.

Tables 2.1 and 2.2 below highlight key elements of these two global treaty instruments that recognize the important role of national planning for achieving their goals and objectives, for both terrestrial and marine environments. Lawyers, planners, and conservation practitioners may find the tables useful as they review existing laws and policies related to national and sector spatial planning and, as needed, work to strengthen planning processes and requirements to support the CBD Aichi Targets and UNFCCC Paris Agreement.

\section{Table 2.1 Aichi Biodiversity Targets with explicit reference to planning}

\section{Strategic Goal A: Address the underlying causes of biodiversity loss by mainstreaming biodiversity across government and society}

\section{Target 2}

By 2020 , at the latest, biodiversity values have been integrated into national and local development and poverty reduction strategies and planning processes and are being incorporated into national accounting, as appropriate, and reporting systems.

\section{Target 3}

By 2020, at the latest, incentives, including subsidies, harmful to biodiversity are eliminated, phased out or reformed in order to minimize or avoid negative impacts, and positive incentives for the conservation and sustainable use of biodiversity are developed and applied, consistent and in harmony with the Convention and other relevant international obligations, taking into account national socio economic conditions.

\section{Strategic Goal B: Reduce the direct pressures on biodiversity and promote sustainable use}

\section{Target 10}

By 2015, the multiple anthropogenic pressures on coral reefs, and other vulnerable ecosystems impacted by climate change or ocean acidification are minimized, so as to maintain their integrity and functioning.

\section{Strategic Goal C: To improve the status of biodiversity by safeguarding ecosystems,} species and genetic diversity

\section{Target 11}

By 2020, at least 17 per cent of terrestrial and inland water, and 10 per cent of coastal and marine areas, especially areas of particular importance for biodiversity and ecosystem services, are conserved through effectively and equitably managed, ecologically representative and well connected systems of protected areas and other effective area-based conservation measures, and integrated into the wider landscapes and seascapes.

Strategic Goal D: Enhance the benefits to all from biodiversity and ecosystem services

\section{Target 14}

By 2020, ecosystems that provide essential services, including services related to water, and contribute to health, livelihoods and well-being, are restored and safeguarded, taking into account the needs of women, indigenous and local communities, and the poor and vulnerable.

\section{Target 15}

By 2020, ecosystem resilience and the contribution of biodiversity to carbon stocks has been enhanced, through conservation and restoration, including restoration of at least 15 per cent of degraded ecosystems, thereby contributing to climate change mitigation and adaptation and to combating desertification. 


\section{Strategic Goal E: Enhance implementation through participatory planning, knowledge management and capacity building}

\section{Target 18}

By 2020, the traditional knowledge, innovations and practices of indigenous and local communities relevant for the conservation and sustainable use of biodiversity, and their customary use of biological resources, are respected, subject to national legislation and relevant international obligations, and fully integrated and reflected in the implementation of the Convention with the full and effective participation of indigenous and local communities, at all relevant levels.

(Source: excerpts from the Aichi Targets, available at https://www.cbd.int/sp/targets)

\section{Table 2.2 UNFCCC Paris Agreement and associated UNESCO principles - key elements}

\begin{tabular}{|c|c|}
\hline Section & Obligations/Principles \\
\hline $\begin{array}{l}\text { UNFCCC Paris } \\
\text { Agreement, Article } \\
7, \text { para. } 7\end{array}$ & $\begin{array}{l}\text { Parties should strengthen their cooperation on enhancing action on adaptation,... } \\
\text { including with regard to: } \\
\text { (a) Sharing information, good practices, experiences and lessons learned, including, } \\
\text { as appropriate, as these relate to science, planning, policies and implementation in } \\
\text { relation to adaptation actions; }\end{array}$ \\
\hline Article 7, para. 9 & $\begin{array}{l}\text { Each Party shall, as appropriate, engage in adaptation planning processes and the } \\
\text { implementation of actions, including the development or enhancement of relevant } \\
\text { plans, policies and/or contributions, which may include: } \\
\ldots \\
\text { (b) The process to formulate and implement national adaptation plans; } \\
\ldots \\
\text { (d) Monitoring and evaluating and learning from adaptation plans, policies, pro- } \\
\text { grammes and actions; and } \\
\text { (e) Building the resilience of socioeconomic and ecological systems, including through } \\
\text { economic diversification and sustainable management of natural resources.... }\end{array}$ \\
\hline Article 7, para. 10 & $\begin{array}{l}\text { Each Party should, as appropriate, submit and update periodically an adaptation com- } \\
\text { munication, which may include its priorities, implementation and support needs, plans } \\
\text { and actions, without creating any additional burden for developing country Parties. }\end{array}$ \\
\hline Artic & $\begin{array}{l}\text { The adaptation communication referred to in paragraph } 10 \text { of this Article shall be, as } \\
\text { appropriate, submitted and updated periodically, as a component of or in conjunc- } \\
\text { tion with other communications or documents, including a national adaptation plan, } \\
\text { a nationally determined contribution as referred to in Article } 4 \text {, paragraph } 2 \text {, and/or a } \\
\text { national communication. }\end{array}$ \\
\hline Article 9, para. 9 & $\begin{array}{l}\text { The institutions serving this Agreement, including the operating entities of the Finan- } \\
\text { cial Mechanism of the Convention, shall aim to ensure efficient access to financial re- } \\
\text { sources through simplified approval procedures and enhanced readiness support for } \\
\text { developing country Parties, in particular for the least developed countries and small } \\
\text { island developing States, in the context of their national climate strategies and plans. }\end{array}$ \\
\hline $\begin{array}{l}\text { UNESCO Ethical } \\
\text { principles for } \\
\text { climate change } \\
\text { implementation - } \\
\text { preamble }\end{array}$ & $\begin{array}{l}\text {...Noting with great concern that there is an urgent imperative to mitigate the causes } \\
\text { of climate change, and to adapt to its consequences, } \\
\text { Noting with concern that climate change exacerbates other threats to social and nat- } \\
\text { ural systems, which place additional burdens on the poor and vulnerable,... } \\
\text {...recognizing that meaningful participation of all stakeholders, including the most } \\
\text { vulnerable, is essential to effective decision-making to address climate change and } \\
\text { its adverse effects, }\end{array}$ \\
\hline
\end{tabular}




\begin{tabular}{|c|c|}
\hline Section & Obligations/Principles \\
\hline $\begin{array}{l}\text { Principles } \\
\text { especially relevant } \\
\text { for incorporation in } \\
\text { spatial planning- } \\
\text { related policy and } \\
\text { law }\end{array}$ & $\begin{array}{l}\text {...Recalling that the principles and provisions of the UNFCCC, the Kyoto Protocol, and } \\
\text { the Paris Agreement adopted under the Convention, guide States in the global effort } \\
\text { against climate change, the following principles should be considered, respected and } \\
\text { promoted within the scope of this Declaration, and in decisions taken or actions carried } \\
\text { out in responding to climate change: } \\
\ldots \\
\text { Article 2: Prevention of Harm } \\
\text { Article 3: Precautionary Approach } \\
\text { Article 4: Equity and Justice } \\
\text { Article 5: Sustainable Development } \\
\text { Article 6: Solidarity } \\
\text { Article 7: Scientific Knowledge and Integrity in Decision-Making } \\
\text { Article 8: Science, Technologies and Innovations } \\
\text { Article 9: Risk assessment and management } \\
\text { Article 10: Vulnerable groups } \\
\text { Article 11: Education } \\
\text { Article 12: Public Awareness } \\
\text { Article 13: Responsibility } \\
\text { Article 14: International Co-operation }\end{array}$ \\
\hline
\end{tabular}

(Source: UNFCCC Paris Agreement at https://unfccc.int/sites/default/files/english_paris_agreement.pdf, and UNESCO Declaration of Ethical Principles in Relation to Climate Change at http://unesdoc.unesco.org/ images/0026/002601/260129e.pdf)

\subsubsection{Global policy - UN Sustainable Development Goals}

Turning to global policy instruments, a recently-adopted document is especially relevant here. (It is not possible within the scope of this project to cover the many global, regional and bilateral policy declarations to which particular countries may have made commitments with implications for spatial planning; but those need local attention as well.)

The recent global policy particularly important for guiding country spatial planning objectives and actions is the SDGs mentioned above, also called the 'Global Goals'. Adopted in September 2015 by more than 150 world leaders at the United Nations Sustainable Development Summit, this policy is a universal call to action to achieve sustainable development. Comprised of 17 specific goals and 169 targets, it is framed as the new 2030 Agenda for Sustainable Development to end poverty, protect the planet and ensure that all people enjoy peace and prosperity.

As explained by UNDP, the lead UN implementing agency, these goals build on the successes of the 2000 Millennium Development Goals (8 international development goals that countries committed to by the year 2015 following the UN Millennium Summit in 2000) (see http://www.undp.org/content/ undp/en/home/sustainable-development-goals.html). The SDGs go beyond the 2000 declaration, recognizing new areas of for attention such as climate change, economic inequality, innovation, sustainable consumption, and peace and justice, among others. The goals are interconnected often the key to success on one will involve tackling issues more commonly associated with another. National planning systems are expected to play a central role in implementing these goals, including integration across sectors and levels of decision making from central to local levels. See Table 2.3 below on specific SDGs that explicitly recognize the need for planning for their achievement. 


\section{Table 2.3 Sustainable Development Goals and spatial planning}

\begin{tabular}{|c|c|}
\hline Section & Text/target \\
\hline Declaration & $\begin{array}{l}\text { Para. } 55 \text { The Sustainable Development Goals and targets are integrated and indivis- } \\
\text { ible, global in nature and universally applicable, taking into account different national } \\
\text { realities, capacities and levels of development and respecting national policies and } \\
\text { priorities. Targets are defined as aspirational and global, with each Government setting } \\
\text { its own national targets guided by the global level of ambition but taking into account } \\
\text { national circumstances. Each Government will also decide how these aspirational and } \\
\text { global targets should be incorporated into national planning processes, policies and } \\
\text { strategies. It is important to recognize the link between sustainable development and } \\
\text { other relevant ongoing processes in the economic, social, and environmental fields. }\end{array}$ \\
\hline $\begin{array}{l}\text { Goal 11: Make cities } \\
\text { and human } \\
\text { settlements } \\
\text { inclusive, safe, } \\
\text { resilient and } \\
\text { sustainable }\end{array}$ & $\begin{array}{l}11.3 \text { By } 2030 \text {, enhance inclusive and sustainable urbanization and capacity for par- } \\
\text { ticipatory, integrated, and sustainable human settlement planning and management } \\
\text { in all countries } \\
\text { 11.a Support positive economic, social and environmental links between urban, } \\
\text { peri-urban and rural areas by strengthening national and regional development } \\
\text { planning } \\
\text { 11.b By } 2020 \text {, substantially increase the number of cities and human settlements } \\
\text { adopting and implementing integrated policies and plans toward inclusion, resource } \\
\text { efficiency, mitigation and adaptation to climate change, resilience to disasters, and } \\
\text { develop and implement ... holistic disaster risk management at all levels }\end{array}$ \\
\hline $\begin{array}{l}\text { Goal 13: Take urgent } \\
\text { action to combat } \\
\text { climate change and } \\
\text { its impacts }\end{array}$ & $\begin{array}{l}\text { 13.2 Integrate climate change measures into national policies, strategies, and } \\
\text { planning } \\
\text { 13.b. Promote mechanisms for raising capacity for effective climate change-related } \\
\text { planning and management in least developed countries and small island developing } \\
\text { states, including focusing on women, youth, and local and marginal communities }\end{array}$ \\
\hline $\begin{array}{l}\text { Goal 14: Conserve } \\
\text { and sustainably use } \\
\text { the oceans, seas } \\
\text { and marine } \\
\text { resources for } \\
\text { sustainable } \\
\text { development }\end{array}$ & $\begin{array}{l}14.4 \text { By } 2020 \text {, effectively regulate harvesting and end overfishing, illegal, unre- } \\
\text { ported and unregulated fishing and destructive fishing practices and implement } \\
\text { science-based management plans, in order to restore fish stocks in the shortest time } \\
\text { feasible, at least to levels that can produce maximum sustainable yield as determined } \\
\text { by their biological characteristics }\end{array}$ \\
\hline $\begin{array}{l}\text { Goal 15: Protect } \\
\text { restore and promote } \\
\text { sustainable use of } \\
\text { terrestrial } \\
\text { ecosystems, } \\
\text { sustainably manage } \\
\text { forests, combat } \\
\text { desertification, and } \\
\text { halt and reverse } \\
\text { land degradation } \\
\text { and halt biodiversity } \\
\text { loss }\end{array}$ & $\begin{array}{l}15.9 \text { By } 2020 \text {, integrate ecosystem and biodiversity values into national and local } \\
\text { planning, development processes, poverty reduction strategies and accounts }\end{array}$ \\
\hline $\begin{array}{l}\text { Goal 17: Strengthen } \\
\text { the means of } \\
\text { implementation and } \\
\text { revitalize the Global } \\
\text { Partnership for } \\
\text { Sustainable } \\
\text { Development }\end{array}$ & $\begin{array}{l}17.9 \text { Enhance international support for implementing effective and targeted capacity } \\
\text { building in developing countries to support national plans to implement all the Sus- } \\
\text { tainable Development Goals, including through North/South, and South/South and } \\
\text { triangular cooperation }\end{array}$ \\
\hline
\end{tabular}




\begin{tabular}{|l|l|}
\hline \multicolumn{1}{|c|}{ Section } & \multicolumn{1}{c|}{ Text/target } \\
\hline $\begin{array}{l}\text { Means of } \\
\text { Implementation and } \\
\text { the Global } \\
\text { Partnership }\end{array}$ & $\begin{array}{l}\text { Para. 78: We encourage all Member States to develop as soon as practical ambitious } \\
\text { national responses to the overall implementation of this Agenda. These can support } \\
\text { the transition to the Sustainable Development Goals and build on existing planning } \\
\text { instruments, such as national development and sustainable development strategies, } \\
\text { as appropriate. }\end{array}$ \\
& $\begin{array}{l}\text { Para. 88 We also stress the importance of system-wide strategic planning, implemen- } \\
\text { tation and reporting in order to ensure coherent and integrated support to the imple- } \\
\text { mentation of the new Agenda by the UN development system. The relevant governing } \\
\text { bodies should take action to review such support to implementation and to report } \\
\text { on progress and obstacles. We welcome the ongoing dialogue in the Economic and } \\
\text { Social Council on the longer term positioning of the UN development system and look } \\
\text { forward to taking action on these issues, as appropriate. }\end{array}$ \\
\hline
\end{tabular}

(Source: Excerpts from the SDG text, emphasis added. At: https://sustainabledevelopment.un.org)

In 2016, several UN agencies joined together in the Partnership for Action on Green Economy (PAGE), rallying for the importance of the SDGs for countries and the international community, declaring that:

SDGs have the potential to promote integration, coordination and coherence across the policy/planning cycle.... In designing and monitoring their work, national agencies concerned with a specific goal (e.g., education, health, economic growth) will be aware, through the SDG framework, of targets that refer to other goals. This, in turn, can spur cross-sector, integrated work. Such drivers will also apply to international development agencies and so may influence their planning and funding. (PAGE, 2016, p. 16)

\subsubsection{Other relevant treaties and international programmes}

Other global and regional treaties to which the country is a Party may also have spatial planning implications (military, trans-oceanic cables, shipping, airline routes, etc.) Of particular relevance here are several conservation-related treaties and agreements involving spatial designations and protections with special land, marine, ecosystem, or species management measures. These measures need incorporation in national spatial planning processes and plans, and follow-through on the ground. Such treaties deal with protected areas and conserved areas of different governance types, specific ecosystems (e.g., wetlands), protected species and their critical habitats, endangered species migratory ranges, and connectivity conservation of species or ecosystems.

Table 2.4 below lists some of other major international treaties and programmes that have elements important to reflect in the spatial plan according to its designation under the respective treaty or programme. A more general discussion of these global treaties and their significance for conservation planning can be found in the IUCN Guidelines for Protected Areas Legislation (2011) and its complementary piece, The Legal Aspects of Connectivity Conservation - A Concept Paper (2013). This Table is drawn from those two sources.

The first part of Table 2.4 focuses on key global treaties mostly in terrestrial environments which require consideration in spatial planning processes and instruments. Many of these also trigger connectivity needs. A second part covers a selection of key regional law instruments and the supranational legal framework of the European Union, with a focus on selected elements relevant for integrated spatial planning. A third part singles out key global and regional instruments for marine environments and marine conservation with implications for marine spatial planning including for connectivity, including some of the same instruments listed above. This Table is not exhaustive, but illustrative. For any country or region there will surely be additional instruments of global, regional or 
bilateral scope requiring integration of biodiversity and climate change elements into spatial planning across borders, both land and marine.

\section{Table 2.4 International conservation treaties and programmes with planning requirements}

\begin{tabular}{|c|c|c|}
\hline $\begin{array}{c}\text { Geographic } \\
\text { scope }\end{array}$ & $\begin{array}{c}\text { Subject focus/ } \\
\text { instrument }\end{array}$ & Discussion/comments \\
\hline \multicolumn{3}{|c|}{ Part 1: Global law and policy instruments } \\
\hline \multirow[t]{5}{*}{$\begin{array}{l}\text { Global scope, } \\
\text { terrestrial }\end{array}$} & $\begin{array}{l}\text { Convention on } \\
\text { Biological Diversity } \\
\text { (CBD) - treaty text }\end{array}$ & $\begin{array}{l}\text { Textual items of special relevance: Art. } 8 \text { refers to a 'system' } \\
\text { of protected areas and other "areas where special measures } \\
\text { need to be taken to conserve biological diversity". Art. } 6 \text { calls } \\
\text { for integration of biodiversity conservation into other relevant } \\
\text { sectoral or cross-sectoral plans, programmes and policies, } \\
\text { e.g., infrastructure and agriculture where there are far-reach- } \\
\text { ing implications for connectivity. These need reflection in spa- } \\
\text { tial plans. }\end{array}$ \\
\hline & $\begin{array}{l}\text { CBD commitments } \\
\text { and guidelines }\end{array}$ & $\begin{array}{l}\text { E.g., Aichi Target } 11 \text { calls for 'well-connected systems of } \\
\text { PAs and other effective area-based conservation measures } \\
\text { integrated into the wider landscapes/seascapes. CBD Pro- } \\
\text { gramme of Work on PAs calls for establishment and man- } \\
\text { agement of ecological networks, ecological corridors, buffer } \\
\text { zones, among other things. } 2010 \text { CBD decision on PAs calls } \\
\text { for enhancing the coverage and quality, representativeness } \\
\text { and, if appropriate, connectivity of PAs. Another } 2010 \text { CBD } \\
\text { decision related to climate change adaptation calls on Parties } \\
\text { to strengthening protected area networks, including through } \\
\text { connectivity measures, and integration within broader land- } \\
\text { scapes/seascapes. These mandates need incorporation in } \\
\text { spatial planning. }\end{array}$ \\
\hline & $\begin{array}{l}\text { CBD technical } \\
\text { series }\end{array}$ & $\begin{array}{l}\text { Including a comprehensive analysis of the three-way con- } \\
\text { nections between spatial planning, biodiversity and climate } \\
\text { change (No. } 41 \text { ) }\end{array}$ \\
\hline & $\begin{array}{l}\text { Climate Change } \\
\text { Convention }\end{array}$ & $\begin{array}{l}\text { Calls for national and regional programmes to facilitate ad- } \\
\text { equate adaptation. Importantly, it also creates mechanisms, } \\
\text { especially REDD+, which give opportunities for conservation } \\
\text { and sustainable use of forests and biodiversity, including for } \\
\text { connectivity and climate change adaptation. These opportu- } \\
\text { nities should be taken into account in spatial plans. }\end{array}$ \\
\hline & $\begin{array}{l}\text { Convention on } \\
\text { Migratory Species } \\
\text { (CMS) }\end{array}$ & $\begin{array}{l}\text { CMS aims for a 'favourable conservation status' for migratory } \\
\text { species, with mandates for endangered species (App. 1) and } \\
\text { other species in an unfavourable conservation status (App. } \\
\text { 2). Protection of connectivity areas may be essential, forex- } \\
\text { ample, to prevent or minimize adverse effects of activities or } \\
\text { obstacles that seriously impede or prevent species migra- } \\
\text { tion (i.e., roads, fences, wind farms, power lines, and other } \\
\text { infrastructure that could impair connectivity) (Art. III(4)). The } \\
\text { CMS Conference of the Parties (COP) has acknowledged that } \\
\text { the objectives of the Convention cannot be met without ade- } \\
\text { quate protection of space for connectivity conservation, and } \\
\text { has urged a network approach to implementation of existing } \\
\text { CMS initiatives and instruments (Res. 10.3, 2011). It envisions } \\
\text { ancillary instruments among range states to protect specific } \\
\text { species (see more below under section 2). These principles } \\
\text { should be an integral part of spatial planning and resulting } \\
\text { plans. }\end{array}$ \\
\hline
\end{tabular}




\begin{tabular}{|c|c|c|}
\hline $\begin{array}{l}\text { Geographic } \\
\text { scope }\end{array}$ & $\begin{array}{c}\text { Subject focus/ } \\
\text { instrument }\end{array}$ & Discussion/comments \\
\hline & $\begin{array}{l}\text { Ramsar Convention } \\
\text { (Convention on } \\
\text { Wetlands of Inter- } \\
\text { national Importance } \\
\text { especially as } \\
\text { Waterfowl Habitat) }\end{array}$ & $\begin{array}{l}\text { Obligation to promote conservation of wetlands and water- } \\
\text { fowl by establishing nature reserves on wetlands, formulating } \\
\text { and implementing plans to promote conservation of wetlands } \\
\text { on the official Ramsar list and also wise use of all wetlands in } \\
\text { their territory. Also, Parties are obliged to consult on trans- } \\
\text { boundary wetlands. All such actions have implications for } \\
\text { spatial protection, at least for connectivity. In addition, Parties } \\
\text { acknowledged the importance of providing corridors and fly- } \\
\text { ways along wetlands to help species adapt to climate change } \\
\text { (Res. X.24, 2008). [see also marine section below] }\end{array}$ \\
\hline & $\begin{array}{l}\text { World Heritage } \\
\text { Convention (WHC) }\end{array}$ & $\begin{array}{l}\text { Several ecologically important sites around the world qualify } \\
\text { as natural heritage. Art. } 5 \text { calls on Parties to endeavour to in- } \\
\text { tegrate protection of their natural heritage into comprehensive } \\
\text { planning programmes and to take appropriate measures to } \\
\text { identify, protect, and rehabilitate that heritage, an obligation } \\
\text { that may need to extent to connectivity, particularly for listed } \\
\text { large wetlands, mountain ranges, volcanoes, and large scale } \\
\text { wildlife corridors. In addition, WHC operational guidelines call } \\
\text { for adequate buffer zones where necessary for proper conser- } \\
\text { vation. These considerations need to be reflected in modern } \\
\text { spatial plans. }\end{array}$ \\
\hline $\begin{array}{l}\text { Global } \\
\text { Programmes, } \\
\text { terrestrial }\end{array}$ & $\begin{array}{l}\text { UNESCO Man and } \\
\text { the Biosphere } \\
\text { Programme (MAB) }\end{array}$ & $\begin{array}{l}\text { The MAB biosphere reserve concept organizes areas impor- } \\
\text { tant for conservation into three zones: core, buffer, and tran- } \\
\text { sition. The programme is guided by a Statutory Framework of } \\
\text { the World Network of Biosphere Reserves which functions as } \\
\text { a legal framework to guide states with development of sites as } \\
\text { part of the network. }\end{array}$ \\
\hline \multicolumn{3}{|c|}{ Part 2: Selected regional and supranational law instruments } \\
\hline \multirow[t]{2}{*}{ Regional scope } & African Convention & $\begin{array}{l}\text { While the convention does not explicitly reference spatial } \\
\text { planning, the overarching obligation of Parties is to undertake } \\
\text { measures necessary to ensure conservation, use, and devel- } \\
\text { opment of soil, water, flora, and fauna in accordance with sci- } \\
\text { entific principles (Art. 2); such measures in many cases require } \\
\text { special spatial treatment, including for connectivity conserva- } \\
\text { tion. There also is an obligation to give special protection to } \\
\text { species threatened with extinction, including habitat protec- } \\
\text { tion through different types of conservation areas (Arts. 8, 10), } \\
\text { an obligation needing attention in spatial planning. Also, the } \\
\text { Convention calls on Parties to ensure that development plans } \\
\text { give full consideration to ecological factors (Art. 8). }\end{array}$ \\
\hline & $\begin{array}{l}\text { Bern Convention } \\
\text { (Convention on the } \\
\text { Conservation of } \\
\text { European Wildlife } \\
\text { and Natural } \\
\text { Habitats) }\end{array}$ & $\begin{array}{l}\text { An 'Emerald Network' of Areas of Special Conservation Inter- } \\
\text { est is set up under the Convention. Convention obliges Parties } \\
\text { to conserve wild species and their natural habitats, including } \\
\text { migratory ones (Art. 1), take requisite measures to maintain } \\
\text { the population of wild species at a level corresponding to eco- } \\
\text { logical requirements (Art. 2), avoid or minimize deterioration } \\
\text { of natural habitats in their plans and development policies - } \\
\text { duties which call for adequate spatial planning for these con- } \\
\text { servation needs, including for connectivity. The Convention } \\
\text { treaty body, called a Standing Committee, has recommended } \\
\text { conservation and restoration of ecological corridors, includ- } \\
\text { ing watercourses, outside formal protected areas by such } \\
\text { measures as building special tunnels and cerviducts so that } \\
\text { roads, railways, and high-voltage lines do not prevent }\end{array}$ \\
\hline
\end{tabular}




\begin{tabular}{|c|c|c|}
\hline \multirow[t]{2}{*}{$\begin{array}{c}\text { Geographic } \\
\text { scope }\end{array}$} & $\begin{array}{c}\text { Subject focus/ } \\
\text { instrument }\end{array}$ & Discussion/comments \\
\hline & & $\begin{array}{l}\text { migrations or interchanges, and by establishing networks of } \\
\text { interconnected protected areas and intervening habitat mo- } \\
\text { saics to increase permeability and aid gene flow, and restoring } \\
\text { large intact habitats and large-scale connectivity. }\end{array}$ \\
\hline & $\begin{array}{l}\text { CMS ancillary } \\
\text { instruments }\end{array}$ & $\begin{array}{l}\text { Various ancillary instruments are, or could be, vehicles for co- } \\
\text { ordinated spatial planning for relevant habitat and ecosystem } \\
\text { protection to address conservation and connectivity needs of } \\
\text { specified endangered species. One example of a legally-bind- } \\
\text { ing agreement is the African-Eurasian Waterbirds Agreement } \\
\text { (AEWA) covering the entire African-Eurasian flyway for mi- } \\
\text { gratory waterfowl, laying out obligations for conservation of } \\
\text { the listed species and their habitats, including planning and } \\
\text { construction of structures to minimize impact on the popu- } \\
\text { lations concerned. Another example is the Gorilla Agreement } \\
\text { requiring coordinated measures to maintain or restore gorillas } \\
\text { in a favourable conservation status, including by ensuring that } \\
\text { a network of suitable habitats is maintained or re-established } \\
\text { throughout the entire range. An example of a non-legally bind- } \\
\text { ing instrument is the Eastern Europe Bukhara Deer MoU with } \\
\text { a commitment to conserve and restore that species and its } \\
\text { habitat, and an Action Plan promoting the creation of an in- } \\
\text { terstate econet of protected areas to sustain the population. } \\
\text { See http://www.cms.int/en/cms-instruments/mou for full list } \\
\text { of agreements and MoUs. }\end{array}$ \\
\hline & $\begin{array}{l}\text { Other regional } \\
\text { instruments }\end{array}$ & $\begin{array}{l}\text { There are many more regional conservation legal instruments } \\
\text { with obligations and commitments requiring supportive spa- } \\
\text { tial planning. Depending on the region and country, examples } \\
\text { include the Convention on Nature Protection and Wildlife } \\
\text { Preservation in the Western Hemisphere, the Convention on } \\
\text { the Conservation of the Biodiversity and Protection of Wil- } \\
\text { derness Areas in Central America, the European Landscape } \\
\text { Convention, the Alpine Convention, the Carpathian Conven- } \\
\text { tion, the Protocol on Environmental Protection to the Antarctic } \\
\text { Treat, relevant CMS ancillary instruments, and in fresh water } \\
\text { management, the Convention on the Protection and Use of } \\
\text { Transboundary Watercourses and International Lakes. }\end{array}$ \\
\hline $\begin{array}{l}\text { European Union } \\
\text { (EU) law and } \\
\text { connectivity } \\
\text { (supranational } \\
\text { scope) }\end{array}$ & $\begin{array}{l}\text { European } \\
\text { Ecological } \\
\text { Network: Natura } \\
2000\end{array}$ & $\begin{array}{l}\text { The two basic legal instruments through which the EU's bio- } \\
\text { diversity and species are protected are the EU Birds Directive } \\
\text { and the Habitats Directive, which together have facilitated } \\
\text { creation of the continent-wide European ecological network } \\
\text { called the Natura } 2000 \text { Network. These directives are bind- } \\
\text { ing on Member States and provide the frameworks for their } \\
\text { national spatial planning and management policies, most of } \\
\text { which go beyond the minimum criteria of the Directives. The } \\
\text { Habitats Directive is particularly relevant for ensuring creation } \\
\text { of an ecological network rather than isolated protected are- } \\
\text { as through its requirement that Member States endeavour to } \\
\text { improve the ecological connectivity of Natura } 2000 \text { by main- } \\
\text { taining, and where appropriate developing features of major } \\
\text { importance to wildlife. Guidance also has been developed to } \\
\text { maintain and restore space for connectivity and to respond to } \\
\text { the impacts of climate change. }\end{array}$ \\
\hline
\end{tabular}




\begin{tabular}{|c|c|c|}
\hline \multirow[t]{3}{*}{$\begin{array}{c}\text { Geographic } \\
\text { scope }\end{array}$} & $\begin{array}{c}\text { Subject focus/ } \\
\text { instrument }\end{array}$ & Discussion/comments \\
\hline & $\begin{array}{l}\text { Birds and Habitats } \\
\text { Directives }\end{array}$ & $\begin{array}{l}\text { In addition to the rules on the Natura } 2000 \text { Network, these } \\
\text { Directives contains rules on species conservation to protect } \\
\text { individual specimens of protected species or their breeding } \\
\text { sites regardless of whether they are Natura } 2000 \text { sites. Such } \\
\text { rules are relevant for spatial planning by requiring such meas- } \\
\text { ures as a system of strict protection of listed animal species } \\
\text { in their natural range; prohibiting deliberate disturbances es- } \\
\text { pecially during period of breeding, rearing, hibernation and } \\
\text { migration; implementing concrete and specific legal protec- } \\
\text { tion measures, and adopting coordinated measures of a pre- } \\
\text { ventive nature. }\end{array}$ \\
\hline & $\begin{array}{l}\text { EU Water frame- } \\
\text { work Directive } \\
\text { (2000/60/EC) }\end{array}$ & $\begin{array}{l}\text { This Directive is part of the extensive EU law and policy frame- } \\
\text { work for water management, including providing opportuni- } \\
\text { ties to manage river basins at a transnational scale in order to } \\
\text { provide European waters and their ecosystems from further } \\
\text { deterioration and to promote sustainable water use. The di- } \\
\text { rective, among other things, obliges Member States to des- } \\
\text { ignate river basin districts, draw up river basin management } \\
\text { plans, and ensure transboundary coordination of the basins. } \\
\text { It provides important support for connectivity by noting that } \\
\text { river continuity is one of the elements for good ecological sta- } \\
\text { tus - a basic goal to be achieved. The directive also underlies } \\
\text { several bilateral and multilateral treaties in the EU, some of } \\
\text { which have programmes with direct implications for spatial } \\
\text { planning, including protecting connectivity, e.g., the } 1999 \\
\text { Rhine Convention. (see also EU Marine Strategy Framework } \\
\text { Directive below) }\end{array}$ \\
\hline \multicolumn{3}{|c|}{ Part 3: Special international marine law/policy instruments } \\
\hline \multirow[t]{2}{*}{$\begin{array}{l}\text { Global scope, } \\
\text { marine }\end{array}$} & $\begin{array}{l}\text { United Nations } \\
\text { Convention on the } \\
\text { Law of the Sea } \\
\text { (UNCLOS) }\end{array}$ & $\begin{array}{l}\text { This is the framework convention for ocean law and a number } \\
\text { of provisions set out general obligations to reflect in marine } \\
\text { spatial planning. Most directly relevant for marine manage- } \\
\text { ment, the treaty establishes an unqualified obligation on all } \\
\text { states to protect and preserve the marine environment (Art. } \\
\text { 192). It also recognizes a number of foundation principles } \\
\text { which further support conservation and sustainable use of } \\
\text { marine resources and should be incorporated in marine spa- } \\
\text { tial planning, including science-based decision making, envi- } \\
\text { ronmental impact assessment, the ecosystem approach and } \\
\text { the precautionary principle. UNCLOS remains the principal } \\
\text { international law instrument specifying the rights and obliga- } \\
\text { tions of all States and other ocean actors in the use of the } \\
\text { world's oceans, and the general objectives and principles } \\
\text { guiding resource protection and sustainable use. It was de- } \\
\text { signed to serve as a unifying framework for numerous, more } \\
\text { specific ocean law agreements (some of which are noted be- } \\
\text { low), and as a foundation for the progressive development of } \\
\text { ocean law at the global and regional levels. }\end{array}$ \\
\hline & $\begin{array}{l}\text { United Nations Fish } \\
\text { Stocks Agreement }\end{array}$ & $\begin{array}{l}\text { This agreement requires states to protect biodiversity and the } \\
\text { marine environment, and exploit and use the covered fisheries } \\
\text { sustainably, with some of its principles explicitly extended to } \\
\text { marine areas under national jurisdiction. The Agreement has } \\
\text { two articles especially relevant for marine spatial planning. } \\
\text { First, it requires wide application of the precautionary ap- } \\
\text { proach within and beyond national marine waters for activities } \\
\text { to conserve, manage, and exploit highly migratory }\end{array}$ \\
\hline
\end{tabular}




\begin{tabular}{|c|c|c|}
\hline \multirow[t]{6}{*}{$\begin{array}{c}\text { Geographic } \\
\text { scope }\end{array}$} & $\begin{array}{c}\text { Subject focus/ } \\
\text { instrument }\end{array}$ & Discussion/comments \\
\hline & & $\begin{array}{l}\text { fish stocks to protect the living marine resources and preserve } \\
\text { the marine environment (Art. 6.1). Second, the Agreement ex- } \\
\text { plicitly requires that conservation and management measures } \\
\text { established for the high seas and those for areas under na- } \\
\text { tional jurisdiction be compatible (Art. 7.2). }\end{array}$ \\
\hline & $\begin{array}{l}\text { International } \\
\text { Maritime } \\
\text { Organization (IMO) } \\
\text { Rules and } \\
\text { Conventions }\end{array}$ & $\begin{array}{l}\text { IMO manages a number of marine environmental treaties } \\
\text { relevant for marine spatial planning. These include two legal } \\
\text { concepts in particular. First, there is authority to designate } \\
\text { particularly sensitive sea areas (PSSAs) that need special } \\
\text { protections because of their ecological, socio-economic, or } \\
\text { scientific significance and the threat of damage by interna- } \\
\text { tional shipping activities. Second, there is authority under } \\
\text { the International Convention for the Prevention of Pollution } \\
\text { from Ships and its Protocol of } 1978 \text { (commonly referred to as } \\
\text { MARPOL), to identify 'special sea areas' requiring adoption of } \\
\text { mandatory measures to prevent sea pollution relating to their } \\
\text { oceanographic and ecological condition and their sea traffic. } \\
\text { Under MARPOL, these special areas have a higher level of } \\
\text { protection then other areas of the sea. }\end{array}$ \\
\hline & $\begin{array}{l}\text { Convention on } \\
\text { Biological Diversity } \\
\text { (CBD) }\end{array}$ & $\begin{array}{l}\text { Apart from the general Programme of Work on Protected Are- } \\
\text { as adopted by the CBD Conference of Parties (COP) in } 2004 \text {, } \\
\text { which also apply to marine protected areas, the COP also } \\
\text { adopted in } 1998 \text { a separate programme of work for marine } \\
\text { and coastal biodiversity. In } 2006 \text {, the COP recognized that } \\
\text { the application of tools beyond and within national jurisdiction } \\
\text { needed to be coherent, compatible, and complementary, and } \\
\text { in } 2008 \text { the COP urged Parties to apply these tools when es- } \\
\text { tablishing MPA networks. Annex II of the } 2008 \text { decision explic- } \\
\text { itly identifies 'connectivity' as one of the five required network } \\
\text { properties and components for selecting areas to be part of } \\
\text { MPA networks. These are important considerations for marine } \\
\text { spatial planning. }\end{array}$ \\
\hline & Ramsar Convention & $\begin{array}{l}\text { Further to the general note above, this Convention defines } \\
\text { wetlands to include areas "with water that is static or flowing, } \\
\text { fresh, brackish or salt, including marine waters the depth of } \\
\text { which at low tide does not exceed } 6 \text { meters. This covers most } \\
\text { coastal zones around the world. In } 2002 \text {, Parties adopted new } \\
\text { guidelines directly relevant for marine spatial planning, includ- } \\
\text { ing recognition that site planning should be one element of a } \\
\text { multi-scale approach to wise use planning and management, } \\
\text { emphasis on the need for integration into broad landscape } \\
\text { and ecosystem planning, such as at the integrated river basin } \\
\text { and coastal zone scale. }\end{array}$ \\
\hline & $\begin{array}{l}\text { World Heritage } \\
\text { Convention Marine } \\
\text { Programme }\end{array}$ & $\begin{array}{l}\text { Marine sites come within the scope of the World Heritage } \\
\text { Convention (discussed above). Operational guidelines pro- } \\
\text { vide that listed sites may include property representing sig- } \\
\text { nificant ongoing ecological and biological processes in the } \\
\text { evolution and development of coastal and marine ecosystems } \\
\text { and communities of plants and animals. Because marine sites } \\
\text { have been significantly under-represented, in } 2005 \text { the World } \\
\text { Heritage Committee approved a World Heritage Marine Pro- } \\
\text { gramme specifically to promote nominations of large-scale } \\
\text { marine areas and MPA networks out to the EEZ. }\end{array}$ \\
\hline
\end{tabular}




\begin{tabular}{|c|c|c|}
\hline $\begin{array}{c}\text { Geographic } \\
\text { scope }\end{array}$ & $\begin{array}{c}\text { Subject focus/ } \\
\text { instrument }\end{array}$ & Discussion/comments \\
\hline & & $\begin{array}{l}\text { As part of national initiatives to identify such sites, it is im- } \\
\text { portant to take a system-wide approach that integrates these } \\
\text { needs within a marine spatial planning framework to ensure } \\
\text { sustainability of the MPAs, their MPA networks, and their con- } \\
\text { nectivity needs. }\end{array}$ \\
\hline & $\begin{array}{l}\text { CMS ancillary } \\
\text { instruments }\end{array}$ & $\begin{array}{l}\text { As discussed over, CMS provides a mechanism for natural } \\
\text { connectivity. Migratory marine animals and their habitats have } \\
\text { been a focus of several legal instruments to address their hab- } \\
\text { itat conservation and connectivity needs. For example, there } \\
\text { have been agreements concluded for conservation of seals } \\
\text { in the Wadden Sea, small cetaceans of the Baltic and North } \\
\text { Seas (ASCOBANS), cetaceans in the Black Sea, Mediterra- } \\
\text { nean Sea and Contiguous Atlantic Area (ACCOBAMS), and } \\
\text { albatrosses and petrels. Examples of Memoranda of Under- } \\
\text { standings (MOUs) include arrangements for conservation of } \\
\text { marine turtles of the Atlantic Coast of Africa, marine turtles } \\
\text { and their habitats of the Indian Ocean and SE Asia, cetaceans } \\
\text { and their habitats in the Pacific Islands Region, and conserva- } \\
\text { tion of migratory sharks. }\end{array}$ \\
\hline $\begin{array}{l}\text { Global } \\
\text { programmes, } \\
\text { marine }\end{array}$ & $\begin{array}{l}\text { MAB Biosphere } \\
\text { Reserves, marine } \\
\text { programme }\end{array}$ & $\begin{array}{l}\text { Marine sites come within the scope of the World Heritage } \\
\text { Convention (discussed above). Marine sites are significantly } \\
\text { under-represented in the World Heritage List and to address } \\
\text { this, the World Heritage Committee approved a World Herit- } \\
\text { age Marine Programme to promote large-scale marine areas } \\
\text { and MPA networks. As part of such initiatives, countries will } \\
\text { need to develop the necessary law and policy tools to sup- } \\
\text { port marine spatial planning and connectivity needs to sustain } \\
\text { MPAs and MPA networks. }\end{array}$ \\
\hline \multirow[t]{2}{*}{$\begin{array}{l}\text { Regional scope, } \\
\text { and supranational, } \\
\text { selected examples }\end{array}$} & $\begin{array}{l}\text { Regional Seas } \\
\text { Agreements }\end{array}$ & $\begin{array}{l}\text { The Regional Seas Programme launched by UNEP in } 1974 \text { fo- } \\
\text { cusses on engaging neighbouring countries to take actions } \\
\text { to protected shared marine resources by agreements and } \\
\text { actions, which today cover more than } 143 \text { countries. Most } \\
\text { regional seas programmes have legally binding conventions } \\
\text { and legally-binding protocols, including in marine protected } \\
\text { areas and marine biodiversity conservation and connectivity } \\
\text { needs, all requiring incorporation in marine spatial planning } \\
\text { processes. }\end{array}$ \\
\hline & $\begin{array}{l}\text { Convention for the } \\
\text { Protection of the } \\
\text { Marine Environment } \\
\text { of the North-East } \\
\text { Atlantic (OSPAR } \\
\text { Convention) }\end{array}$ & $\begin{array}{l}\text { This Convention includes the European Community plus } 15 \\
\text { states and focuses on ecosystem and biological diversity of } \\
\text { the maritime area, including its internal waters, territorial seas } \\
\text { and EEZs of the Contracting Parties as well as a portion of } \\
\text { the high seas. Some OSPAR sites are also Natura } 2000 \text { sites, } \\
\text { which helps to build connectivity at the transnational level as } \\
\text { well as national level. These elements need to be incorporated } \\
\text { in each country's marine spatial plans. }\end{array}$ \\
\hline European Union & Natura 2000 & $\begin{array}{l}\text { As noted above, the Natura } 2000 \text { network requires Member } \\
\text { States to establish special protection areas for birds and spe- } \\
\text { cial areas for other special areas of conservation (SAC) for } \\
\text { other species to maintain or restore a favourable conservation } \\
\text { status. This includes designating necessary SACS within the } \\
\text { Exclusive Economic Zone, and guidelines have been issued } \\
\text { on establishing Natura } 200 \text { sites in the EEZ - all need recor- } \\
\text { dation in spatial planning instruments. }\end{array}$ \\
\hline
\end{tabular}




\begin{tabular}{|c|c|c|}
\hline $\begin{array}{c}\text { Geographic } \\
\text { scope }\end{array}$ & $\begin{array}{l}\text { Subject focus/ } \\
\text { instrument }\end{array}$ & Discussion/comments \\
\hline & $\begin{array}{l}\text { EU Marine } \\
\text { Strategy Framework } \\
\text { Directive (Directive } \\
\text { 2014/89/EU) }\end{array}$ & $\begin{array}{l}\text { This Directive sets out the framework for Member States to } \\
\text { achieve Good Environmental Status (GES) for their respective } \\
\text { marine areas by } 2020 \text {. The definition of GES requires consid- } \\
\text { erations of spatial needs, including connectivity, for determin- } \\
\text { ing such status. In } 2017 \text { the directive was amended to better } \\
\text { link ecosystem components, anthropogenic pressures and } \\
\text { impacts on the marine environment with the Directive's } 11 \text { de- } \\
\text { scriptors and the new Decision on GES. }\end{array}$ \\
\hline & $\begin{array}{l}\text { EU Maritime Spatial } \\
\text { Planning Directive } \\
\text { (2014/89/EU) }\end{array}$ & $\begin{array}{l}\text { This Directive establishes a framework for the } 28 \text { EU Member } \\
\text { States for maritime spatial planning, requiring each Member } \\
\text { State to establish and implement maritime spatial planning } \\
\text { (Art. 4), taking into account land-sea interactions, with ob- } \\
\text { jectives to include support for sustainable development and } \\
\text { growth in the maritime sector, applying an ecosystem-based } \\
\text { approach. The motivation is that competition for maritime } \\
\text { space - for renewable energy equipment, aquaculture and } \\
\text { other uses - has highlighted the need to manage our wa- } \\
\text { ters more coherently. Maritime spatial planning (MSP) works } \\
\text { across borders and sectors to ensure human activities at sea } \\
\text { take place in an efficient, safe and sustainable way. }\end{array}$ \\
\hline
\end{tabular}

(Source: condensed from The Legal Aspects of Connectivity Conservation. A Concept Paper, Lausche et al., 2013, pp. 57-76, and 159-164. See also: Lausche, 2011)

\subsection{Science and technology}

Integrated spatial planning and management are information-intensive activities. These tasks require multi-disciplinary analyses and the integration of scientific, engineering, and economic information as well as local knowledge, in an ongoing process of learning, monitoring, and adjusting. New developments in science and technology in recent decades are significantly advancing the methods and accuracy of planning to address social, economic, and ecological issues over the near and long-term.

\subsubsection{Conservation science, climate science, and integrated planning}

In conservation biology, there have been major advances in understanding issues of scale at which many key ecological and evolutionary processes occur, and current and projected impacts from climate change. Many conservation scientists and practitioners maintain that the future of biodiversity conservation depends on planning efforts applied across large landscapes along the lines of where these natural processes take place (Baldwin et al., 2018). Seascapes would have a similar situation. These many fields of knowledge now enhance the potential capacity of government decision-makers and planners to incorporate best available scientific information into integrated spatial planning for biodiversity conservation and supporting essential ecosystem services.

Conservation science have made much progress in understanding the direct and indirect causes of biodiversity loss, ongoing threats, and the values of nature and links between ecosystem services and human well-being and all life. It has helped policy-makers and communities become more aware of the inherent connectedness between ecological and social well-being and the importance of different spatial tools, including formal and informal protected areas and connectivity areas, for biodiversity conservation.

In support of the CBD, Article 25 of the convention established an open-ended intergovernmental scientific advisory body known as the Subsidiary Body on Scientific, Technical and Technological 
Advice (SBSTTA) to advise the Conference of the Parties (COP) and, as appropriate, its other subsidiary bodies. The functions of this multidisciplinary body, with participation open to all Parties, include to provide assessments of the status of biological diversity, assessments of measures taken in accordance with the provisions of the Convention, and responses to questions that the COP may put to the body. As of July 2018, SBSTTA had met 21 times and produced a total of 223 recommendations to the Conference of the Parties, some of which have been endorsed in full. Such endorsements make these recommendations de facto decisions of the Conference of the Parties. (For more on these meetings, see https://www.cbd.int/sbstta)

Climate science also has made major strides since the 1990s. Today, climate science has sophisticated knowledge and tools for real-time data collection and analyses about climate change-related events and for better projections of future impacts based on different scenarios of warming globally and regionally. Scientific knowledge and information will continue to improve and play a growing role in near and long-term planning for nature resilience and adaptation; accordingly, legal frameworks dealing with spatial planning need to require use of best available science in that planning, taking into account uncertainties and risk as best possible, and adapt to new information as needed. These advances in climate science are helping policy-makers and practitioners make more informed spatial planning decisions based on better understandings of options, timeframes, costs/benefits, and risks.

A significant development for climate change science with major consequences for policy making has been the work of the Intergovernmental Panel on Climate Change (IPCC). IPCC, an international, nonpartisan, scientific body was created by the United Nations in 1988 to monitor scientific knowledge about climate change and its potential environmental and socio-economic impacts. Periodically they produce scientific assessments with policy recommendations, the fifth assessment published in 2014, and the sixth expected in 2021, with each assessment building on the prior one (see http:// www.ipcc.ch).

IPCC assessments include technical reports plus a reader-friendly 'Summary for Policy Makers' (see IPCC, 2018, C.2.4. and B.6.1 and IPCC, 2014a, for the $5^{\text {th }}$ Assessment Summary). The Summary highlights latest findings of changes in the climate, risks and uncertainties, and the intersection of climate mitigation and adaptation goals with other societal goals creating the possibility of cobenefits or adverse side-effects. These scientific advances in understanding are important inputs to continually inform policy-makers, practitioners, communities, and stakeholders about planning and adaptation options for pursuing their sustainable development goals.

\subsubsection{Information technology and data collection}

Equally important, advances in information technology are helping improve data critical for spatial planning, especially for biodiversity conservation and climate change adaptation. Studies remind us that biodiversity data and studies tend to be available only for areas already designated for nature conservation; while some research focused on biodiversity in urban and human-dominated landscapes, the ecological importance of those areas was not systematically investigated (Geneletti, 2008). This created a sort of binary impression, where the space outside protected areas was not important for biodiversity. This led planners to focus on environmental impacts inside protected areas and not so much outside. Also, easily available data to planners, even today, typically consists of a description of features (e.g., vegetation maps, species inventories), not an assessment of their value to humans and life-support systems. 
Furthermore, ecological evaluation is a rather established discipline but most studies target specific problems such as identifying ecological corridors or conservation priorities, rather than assessing the overall biodiversity assets of region (Geneletti, 2008). Even those that do look more broadly at assets still suffer from a number of mistakes, including trying to solve an ill-defined problem (for discussion of this and other common mistakes in conservation priority setting, see, Game et al., 2012). Finally, where suitable data are available, they still may be hard to retrieve, understand and utilize due to the lack of dedicated planning support systems.

Modern planning support systems in the $21^{\text {st }}$ century are fundamentally geospatial information systems that are needed specifically by planners to undertake their professional responsibilities. Today, geospatial data technologies have advanced significantly in their capacity to generate realtime information on useful spatial and temporal scales about land and marine surface conditions, threats, and changes with time, both improvements and degradation. Such data are becoming more readily accessible to users worldwide at little or no cost, and this has created a revolution of information tools for spatial planning and planners.

Geospatial data is generally defined as information referenced to a specific place-normally a set of geographic coordinates-which can be gathered, manipulated, and displayed in real time. The overarching purpose is to understand the features of an area, both terrestrial and marine, including environmental features, degradation, and man-made structures. These features are critical for understanding the current extent of features of areas to be included in the integrated spatial plan. Features of an area are best represented in maps and remote sensing images like aerial photographs.

Geographic Information Systems (GIS) is a geospatial technology focused on applications of available spatial data to a particular real-world problem. Beginning as a concept in a technical paper in 1969, it has evolved from workstation-based software to tools that can now be used in the cloud and via mobile devices. Today it is one of the most widely used and fundamental computer systems for application of spatial data, and has revolutionized the field of cartographic analysis and mapmaking. It has an almost endless range of potential uses in public policy and government decision making, including for land use, environmental, and overall spatial planning.

Table 2.5 below summarizes some of the main geospatial tools and other information sources which may be able to provide important input for designing spatial plans and monitoring effectiveness over the long term. These technologies and information sources are not discrete categories but frequently used in combination to be able deliver specific results. Box 2.1 below explains the basics of Landsat, the enterprise that provides unbroken satellite imagery of the Earth, the information then being used in government and commercial geospatial data bases. 
Tabelle 2.5 Geospatial data technologies and information sources for spatial planning

\begin{tabular}{|c|c|}
\hline Type & Description \\
\hline $\begin{array}{l}\text { Remote sensing } \\
\text { technologies }\end{array}$ & $\begin{array}{l}\text { Technologies that detect electromagnetic radiant energy reflected or emitted from ob- } \\
\text { jects and land/marine surfaces. The characteristics of this radiation can be interpreted } \\
\text { and analyzed to reveal practical information about those objects and surfaces. Ad- } \\
\text { vances in remote sensing technologies in the last few decades have greatly improved } \\
\text { our observation of the environment. }\end{array}$ \\
\hline Aerial photography & $\begin{array}{l}\text { A technique of photographing the Earth's surface or features of its atmosphere or } \\
\text { hydrosphere with cameras mounted on aircraft, rockets, or Earth-orbiting satellites } \\
\text { and other spacecraft. Aerial photos have long been a key source of topographic in- } \\
\text { formation for maps. They are used by planners for mapmaking, for identifying and } \\
\text { interpreting terrain features, for environmental inventories and monitoring, and as a } \\
\text { source of data and digital images for GIS. }\end{array}$ \\
\hline $\begin{array}{l}\text { Microwave radar } \\
\text { imagery }\end{array}$ & $\begin{array}{l}\text { This technology differs from convention photography. Rather than using a passive } \\
\text { system which just senses natural radiation, it uses an active sensing system gener- } \\
\text { ating waves that bounce off objects on the land and are detected by a sensor. Also, } \\
\text { it uses wavelengths well outside the visible spectrum, enabling sensing of surface } \\
\text { features not detected from natural radiation. }\end{array}$ \\
\hline $\begin{array}{l}\text { Satellite digital } \\
\text { imagery }\end{array}$ & $\begin{array}{l}\text { Measures the amount of radiation received from a specific location on the ground. } \\
\text { Two key advantages over traditional aerial photos: I) produces digital data in different } \\
\text { wavelength bans for use in computer imaging and GIS; } 2 \text { ) satellites provide recurring } \\
\text { data of the same location at frequent intervals, providing continual monitoring (where- } \\
\text { as aerial photos are a snapshot in time). The images are produced as picture elements } \\
\text { or pixels of a given resolution, the finer the resolution, the more spatially detailed the } \\
\text { resulting data. Satellite imaging companies sell images by licensing them to govern- } \\
\text { ments and businesses such as Apple Maps and Google Maps. See Box- on Landsat, } \\
\text { the main government programme acquiring satellite imagery of the Earth since } 1972 \text {. }\end{array}$ \\
\hline Digital mapping & $\begin{array}{l}\text { A revolution in spatial environmental data has come through the production and avail- } \\
\text { ability of geospatial data in digital form. This means maps and other spatial products } \\
\text { are not only available in digital form but also downloadable from the Internet. This } \\
\text { includes line data such as roads and streams, scanned images of topographic maps, } \\
\text { digital records of terrain elevations, land use and land cover, digital images of aerial } \\
\text { photographs, and high resolution digital satellite data. Several Government Internet } \\
\text { sites provide searching and ordering of these digital data. One of the easiest to use } \\
\text { is EarthExplorer at https://earthexplorer.usgs.gov/, which covers the entire planet and } \\
\text { online access is freely available. This site can zoom in to roof tops or specific land } \\
\text { cover or land use. }\end{array}$ \\
\hline Internet mapping & $\begin{array}{l}\text { Software advances have brought interactive mapping to the Internet, allowing users } \\
\text { to access environmental geospatial information they specify and do their own assess- } \\
\text { ment of their local environment. Several interactive mapping sites are available with a } \\
\text { wealth of information. Although the results should always be reviewed for accuracy, } \\
\text { they are useful for rapid assessment. The Earth Science Research Institute (Esri) is a } \\
\text { global software company that has developed an internet mapping server (ArcGIS) to } \\
\text { enable users to create an interactive digital map service using location-based analysis } \\
\text { with maps, applications, and reports. Esri supplies geographic information system } \\
\text { software, web GIS and geodatabase management applications, and considered a } \\
\text { world leader in this field. https://www.esri.com/en-us/home }\end{array}$ \\
\hline $\begin{array}{l}\text { Geographic } \\
\text { information } \\
\text { systems (GIS) }\end{array}$ & $\begin{array}{l}\text { GIS is a technology that incorporates geographical features, i.e., spatial data, with } \\
\text { tabular data (called attribute data) about each of the spatial features, thus creating } \\
\text { several data layers and formats. An example would be an agricultural field. The actual } \\
\text { location of the field is the spatial data. Additional data such as owner/tenant of the } \\
\text { field, what is being grown, other uses, most/least productive parts and overall harvest } \\
\text { would make up the attribute data. GIS has potential for almost endless applications. } \\
\text { A good source on latest applications is the annual Esri Map Book tracking }\end{array}$ \\
\hline
\end{tabular}




\begin{tabular}{|c|c|}
\hline Type & Description \\
\hline & $\begin{array}{l}\text { how GIS is providing spatially-based solutions to wide-ranging issues, including those } \\
\text { affecting business, the environment, utilities, transportation, and government. (https:// } \\
\text { www.esri.com/en-us/esri-map-book/map-book-gallery) }\end{array}$ \\
\hline $\begin{array}{l}\text { Environmental } \\
\text { field data }\end{array}$ & $\begin{array}{l}\text { For local land use and spatial planning, local knowledge and field observation and } \\
\text { monitoring of environmental conditions also is essential. Local knowledge and field } \\
\text { studies can verify government monitoring and remote sensing data, fill in blanks of } \\
\text { information not available through the geospatial tools, and involve local groups, land- } \\
\text { owners, rightsholders, and residents who often know more about their local envi- } \\
\text { ronment than government sources and gain their trust, support, and involvement in } \\
\text { the resulting spatial plans. Surveys, questionnaires, interviews, and workshops are all } \\
\text { useful for gaining local knowledge, including historical information. }\end{array}$ \\
\hline $\begin{array}{l}\text { Community } \\
\text { indicators }\end{array}$ & $\begin{array}{l}\text { With spatial plan monitoring, it may be difficult to know what to monitor in order to } \\
\text { effectively measure change, trends, and progress, especially for complex environ- } \\
\text { mental systems, and the variety of information and data that may exist for biodiversity } \\
\text { and climate change. Increasingly, indicators are being used to simplify monitoring and } \\
\text { assessment. An indicator is a single measure of a condition of an environmental ele- } \\
\text { ment that represents the status or quality of that element. An environmental indicator } \\
\text { for biodiversity and its connectivity could be the amount of impervious surface being } \\
\text { reduced or fragmented area being restored. Use of indicators in community planning } \\
\text { has increased in significance not only because they could include environmental fac- } \\
\text { tors, but also economic and social conditions to reflect progress toward sustainability. } \\
\text { Moreover, monitoring such indicators should be a community activity. As with many } \\
\text { things, several sources online provide long lists of environmental and other indicators } \\
\text { from which to draw ones relevant for local conditions. }\end{array}$ \\
\hline $\begin{array}{l}\text { Global Positioning } \\
\text { System (GPS) }\end{array}$ & $\begin{array}{l}\text { GPS is a network of about } 30 \text { satellites orbiting the Earth at an altitude of } 20,000 \mathrm{~km} \text {. } \\
\text { Once it has information on how far away at least three satellites are, your GPS receiver } \\
\text { can pinpoint your location using a process called trilateration. GPS systems are ex- } \\
\text { tremely versatile and can be found in almost any industry sector. They can be used to } \\
\text { map forests, help farmers harvest their fields, and navigate airplanes on the ground or } \\
\text { in the air. GPS systems are used in military applications and by emergency crews to } \\
\text { locate people needing assistance. }\end{array}$ \\
\hline
\end{tabular}

(Information, in large part, extracted and adapted from Randolph, 2004).

\section{Box 2.1 What is Landsat?}

The U.S. National Aeronautics and Space Administration (NASA) and the U.S. Geological Survey (USGS) collaborate on the Landsat Program, and involve partners from around the world. The NASA and USGS web sites provides an overview:

- The Landsat program is the longest-running enterprise for acquiring satellite imagery of Earth, with the longest unbroken data stream of Earth's surface as seen from space since 1972. Landsat 8 was launched in 2013 as the latest satellite in NASA's Landsat series to continue program's critical role in monitoring land cover changes and their residual effects, providing information for understanding and managing the resources needed for human sustainment such as food, water and forests. It provides moderate-resolution imagery, from 15 to 100 meters, of Earth's land surface and polar regions, and crosses every point of the Earth every 16 days, capturing more than 700 images a day, more than double what was possible with Landsat 7 . Landsat 9 is expected to be launched in 2020.

- Landsat monitors impacts of human society on the planet as population continues to grow, surpassing seven billion, and monitors environmental changes. The knowledge gained from 40 years of continuous data contributes to research on climate, carbon cycle, ecosystems, water cycle, biogeochemistry and changes to Earth's surface, as well as our understanding of visible human effects on land surfaces.Its use, over time, has contributed to programmes aiming to improve human and biodiversity health, 
- energy and water management, urban planning, disaster recovery and agriculture monitoring, all providing significant benefits to the world economy.

- The instruments on Landsat satellites have acquired millions of images over the years. The images are a unique resource for global change research and applications in agriculture, cartography, geology, forestry, coastal management, regional planning, surveillance, and education. Landsat data are received and downlinked to ground stations worldwide, and are archived at the USGS EROS Center in Sioux Falls, South Dakota. Landsat data products are processed and made available for download to all users at no charge via EarthExplorer, GloVis, and the LandsatLook Viewer. Landsat images are usually divided into scenes for easy downloading.

(see: https://www.nasa.gov/mission_pages/landsat/overview/index.html; and https://landsat.usgs.gov/landsat-project-description)

Finally, to close this sub-chapter, it is worth re-emphasizing a key point: modern spatial planning will need new kinds of information on the physical space being planned, including physical status, threats, biodiversity resources, ecosystem flows, and projected change, along with socio-economic data and values, vision, and near and long-term priorities of the communities involved. The topic has been given special attention here because spatial planning, as it broadens to incorporate biodiversity conservation and climate change, faces specific challenges with the special skills and capacity needed to effectively use the latest geospatial technology and information so important for modern plan design and ongoing monitoring and management. Maps, aerial photos, satellite images and other data are increasingly available on the internet to provide much of this basic information. Local knowledge also is essential for validating data, filling gaps, and involving the community in plan making and implementation.

Policies and legal frameworks involved with integrated spatial planning, overall or by sector, need to give this topic explicit reference because of its critical importance. For informed decision-making, collection, analysis and use of real-time information appropriate for spatial planning is essential. Legal frameworks should require the planning processes to use the best available information, and appropriate information technology. It should promote the use of Geospatial technologies, including GIS and satellite imagery such as Landsat, for spatial planning and recognize these tools as important for designing and monitoring any spatial plans.

Legal frameworks should also include the duty of gathering local and traditional knowledge about the environmental conditions, including historical information, and indicating this as a responsibility of those involved in preparing and managing spatial plans. Local information should include identification of key land/marine resources on which their livelihoods depend, biodiversity assets and threats, degradation, local awareness about climate change and how to adapt, indicators for monitoring local spatial planning aspects. Necessary training and resources, as needed, also should be recognized in law and policy.

\subsubsection{Global networks for information sharing}

Another modern tool important to recognize in policy and law frameworks as an aid to spatial planning design and monitoring are the various information networks created since adoption of the CBD and UNFCCC treaties. They provide data bases, data updates, scientific information, experiences and lessons being learned with implementation. 
Among useful databases biodiversity are the IUCN World Database of Key Biodiversity Areas (www. keybiodiversityareas) which identifies sites contributing significantly to the global persistence of biodiversity, and the UNEP-WCMC/IUCN World Database on Protected Areas (www.protectedplanet. net/c/world-database-on-protected-areas), the most comprehensive global database of marine and terrestrial protected areas, updated on a monthly basis, and one of the key global biodiversity data sets being widely used by scientists, businesses, governments, International secretariats and others to inform planning, policy decisions and management. Another important database for spatial planning for biodiversity is the IUCN is the Red List of Threatened Species (www.iucnredlist.org). Finally, the IUCN Red List of Ecosystems Categories and Criteria is a global assessment of the status of ecosystems, applicable at local, national, regional and global levels, to determine whether an ecosystem is facing imminent risk of collapse, or whether it is vulnerable, endangered, or critically endangered (www.iucn.org/theme/ecosystem-management/our-work/red-list-ecosystems). This risk is measured by assessing losses in area, degradation or other major changes such as land conversion.

Policy makers, planners, and conservation practitioners are encouraged to take advantage of these real-time interactive, internet-based networks and participate as useful. Of the growing number of internet networks on climate change and biodiversity information, two are further discussed here.

First, there is a Global Biodiversity Information Facility (GBIF) which arose out of a 1999 recommendation of the Biodiversity Informatics Subgroup of the OECD's Megascience Forum. That OECD Subgroup specifically recommended the establishment of a Global Biodiversity Information Facility, to -

...enable users to navigate and put to use vast quantities of biodiversity information, advancing scientific research ... serving the economic and quality-of-life interests of society, and providing a basis from which our knowledge of the natural world can grow rapidly and in a manner that avoids duplication of effort and expenditure.

That recommendation was endorsed by OECD science ministers. In 2001, GBIF was officially established through a Memorandum of Understanding between participating governments (see https://www.gbif.org).

The GBIF today is an international network and research infrastructure funded by the world's governments and aimed at providing anyone, anywhere, open access to data about all types of life on Earth. Coordinated through its Secretariat in Copenhagen, the GBIF network of participating countries and organizations, working through participant nodes, provides data-holding institutions around the world with common standards and open-source tools that enable them to share information about where and when species have been recorded. This knowledge derives from many sources, including everything from museum specimens collected in the 18th and 19th century to geotagged smartphone photos shared by amateur naturalists in recent days and weeks.

According to its website, the Secretariat is currently organized into four teams, mentioned here to give a sense of scope of their work and service possibilities:

- Participation and Engagement: responsible for operating the network of Participants and publishers, recruiting new members and enhancing the capacity of current ones.

- Data Products: responsible for the quality and scientific value of the integrated data products produced by the GBIF network. 
- Informatics: responsible for data management, software development and the overall operation of the GBIF infrastructure.

- Administration: responsible for maintaining both the network and the Secretariat's underlying operations and processes. (https://www.gbif.org/what-is-gbif)

Second, in climate change, global information networks also are expanding, particularly as new treaty elements are adopted under the UNFCCC. The network created as part of the Convention machinery is the climate change information clearing house network (CC:iNet). This is a web-based clearinghouse for sources on public information, education and training in the field of climate change. Launched as a prototype in 2005, the network's overall purpose is to support and advance the Convention's Article 6 (Education, Training, and Public Awareness) by facilitating international cooperation and providing links to useful or inspiring materials, programmes, campaigns, initiatives, experts and organizations. It is designed to help governments, organizations and individuals gain rapid and easy access to ideas, strategies, contacts, experts and materials that can be used to motivate and empower people to take effective action on climate change. In December 2010, the full-scale version of CC:iNet was launched to facilitate the implementation of the amended New Delhi work programme on Article 6 of the Convention (UNReport: FCCC/SBI/2012/4, March 19, 2012).

Managed by the UNFCCC Secretariat, the network is promoted as a good platform for Parties, especially for developing country Parties to have access to information on climate change. There are two levels of access: the general public and registered users. The general public has full access to search and retrieve information containing the CC:iNet information pool. Registered users have the ability to contribute information directly into CC:iNet, i.e. programmes or initiatives, web-sites, or events, promoting education, training, public awareness and participation, access to information or international cooperation. who can access information free, and registered users who also can contribute relevant content to the data base. CC:iNet can be accessed through the www.unfccc.int homepage.

\subsection{Governance}

In recent decades, governance has become a mainstream topic for conservation and sustainable resource use. The concept has generated significant research, case studies, and international guidance. This is especially the case for formal protected areas, indigenous and community conserved areas (sometimes abbreviated as ICCAs), connectivity areas, and other effective conservation measures protecting biodiversity and ecosystem functions. In the context of these conservation efforts, there is growing global consensus that governance must be broadened beyond government to other involved and concerned governance actors - local communities, indigenous and traditional peoples, NGOs, private corporations, and individuals.

Moreover, in an effort to recognize and promote effective governance arrangements, in 2017 IUCN launched the Green List of Protected and Conserved Areas Programme (the 'IUCN Green List Programme') to encourage, achieve and promote effective, equitable and successful protected areas in all partner countries and jurisdictions, and to improve the contribution that equitably governed and effectively managed protected areas make to sustainable development through the conservation of nature and provision of associated social, economic, cultural, and spiritual values (www.iucn. org/theme/protected-areas/our-work/iucn-green-list-protected-and-conserved-areas.) Today, as a result of historic evolution and more active participation by local groups, governance arrangements in and around protected areas can be quite diverse and are increasingly recognized. 
This perspective on a broader recognition of all governance actors is increasingly being accepted as an integral part of government decision making affecting those actors, their rights, responsibilities, and livelihoods. The expanded concept is directly applicable to all aspects of spatial planning, from preparation to implementation and evaluation. It means open and ongoing participation of all involved actors (inside and outside government) and respect for their interests, rights, and supporting roles in advancing the goals of the integrated spatial plan.

For effective spatial planning, governance actors must be cooperative and open to resolving use conflicts. Collaboration, negotiation, and compromise in plan design and implementation must proceed in a spirit of fairness, social equity, and benefit sharing.

IUCN gives governance significant emphasis in matters of biodiversity conservation and sustainable use. The organization, through WCPA and other commissions, has provided extensive guidance on the meaning of governance and its application. Governance' has two dimensions: how decisions are made, and who makes the decisions. The dimension of 'how' concerns ensuring transparency and participation, social equity and justice in decision-making processes. Such principles are fully applicable to any decision-making on design, management, monitoring, evaluation, or revision of an integrated spatial plan.

The dimension of 'who' relates to types of governance or governance authorities in charge. Areas covered by an integrated spatial plan may have a variety of tenure situations ('tenure' being who owns or controls the land or resource rights). Recognizing a diversity of governance authorities is particularly critical for large-scale terrestrial, freshwater, or marine areas which may be used and occupied for a variety of human purposes. Such areas commonly will have a mixture of tenures as well as many diverse stakeholders needing coordination and involvement.

The concept of governance types emerged in the context of protected area governance at the World Parks Congress in 2003. The IUCN first defined governance types were first defined and applied in the Guidelines for Applying Protected Area Management Categories (Dudley, 2008). They are now comprehensively covered in Governance of Protected Areas: From Understanding to Action (BorriniFeyerabend et al., 2013)

Both IUCN and the CBD today recognise four broad protected area governance types, defined on the basis of who holds authority, responsibility and can be held accountable for the key decisions for protected areas. These types apply equally to lands around protected and areas where tenure rights are diverse and rest with non-state agents, and should be taken into account in spatial plans. The four types of land/sea spatial governance:

a) Governance by government - classic governance approach for conservation and land/sea management for sustainable use; the principle being that government is acting in the public interest., e.g., national or subnational ministry, or delegation of various responsibilities by contract to others, e.g., NGOs, local communities.

b) Governance by indigenous peoples and local communities - especially for those areas or territories where indigenous peoples or local communities have customary, traditional, or statutory tenure rights to the land/sea space or resources.

c) Private governance - where individuals, non-profit groups, or for-profit corporations are landowners or rightsholders (especially in marine environments), or have other tenure rights over the land/sea space or resources. 
d) Shared or collaborative governance -mixed authorities, with joint or co-management, including transboundary management.

Table 2.6 below illustrates these four types and 11 sub-types. The Table reflects the basic form, nature of the sub-categories, and considerations which policy-makers and legal drafters should take into account when drafting or reviewing spatial planning legislation.

\section{Table 2.6 IUCN Governance Types}

\begin{tabular}{|c|c|c|}
\hline Governance Type & Sub-types & Institutional options \\
\hline $\begin{array}{l}\text { Type A } \\
\text { Governace by government }\end{array}$ & $\begin{array}{l}\text { - Federal or national ministry or agency in } \\
\text { charge } \\
\text { - Sub-national ministry or agency in charge } \\
\text { (e.g., at regional, provincial, municipal level) } \\
\text { - Government-delegated management } \\
\text { (e.g., to an NGO) }\end{array}$ & $\begin{array}{l}\text { National, } \\
\text { Sub-national, } \\
\text { Delegation }\end{array}$ \\
\hline $\begin{array}{l}\text { Type B } \\
\text { Shared governance }\end{array}$ & $\begin{array}{l}\text { - Transboundary governance (formal arrange- } \\
\text { ments between one or more sovereign States } \\
\text { or Territories) } \\
\text { - Collaborative governance (through various } \\
\text { ways in which diverse actors and instititions } \\
\text { work together) } \\
\text { - Joint governance (pluralist board or other } \\
\text { multi-party governing body) }\end{array}$ & $\begin{array}{l}\text { Joint, } \\
\text { Collabora }\end{array}$ \\
\hline $\begin{array}{l}\text { Type C } \\
\text { Private governance }\end{array}$ & $\begin{array}{l}\text { - Conserved areas established and run by: } \\
\text { - } \text { individual landowners } \\
\text { - non-profit organisations } \\
\text { (e.g., NGOs, universities) } \\
\text { - } \text { for-profit organisations } \\
\text { (e.g., corporate landowners) }\end{array}$ & $\begin{array}{l}\text { Individual, } \\
\text { Corporations, } \\
\text { NGOs }\end{array}$ \\
\hline $\begin{array}{l}\text { Type D } \\
\text { Governance by indigenous } \\
\text { peoples and local } \\
\text { communities }\end{array}$ & $\begin{array}{l}\text { - Indigenous peoples' conserved territories and } \\
\text { areas - established and run by } \\
\text { indigenous peoples } \\
\text { - Community conserved areas and territories - } \\
\text { established and run by local communities }\end{array}$ & $\begin{array}{l}\text { Indigenous, } \\
\text { traditional, lo } \\
\text { communities }\end{array}$ \\
\hline
\end{tabular}

(Source: Borrini-Feyerabend et al., 2013, p. 29; Governance types and principles are also covered extensive in other recent IUCN publications, including Dudley 2008/2013; and Lausche, 2011)

There is a growing recognition in planning literature that the effectiveness of spatial planning on the ground requires local level involvement from the beginning and where capacity exists, deferring responsibilities to local governance. The notion goes beyond local formal government agencies, to community groups, neighbourhoods, workers, businesses, and organizations that may be affected or have interests. Affected communities and individuals, especially those with tenure to the use of physical space, need equal opportunity, where desired, to have a planning and implementing role in decisions affecting their physical space.

There is a continuum of possibilities for governance responsibilities at the local level, from government governance to a mix of responsibilities, depending on agreement and capacity, and full self-governance by non-governmental entities at the other. Figure 2.1 illustrates this range in simplified form. 


\section{Understanding Governance Diversity}

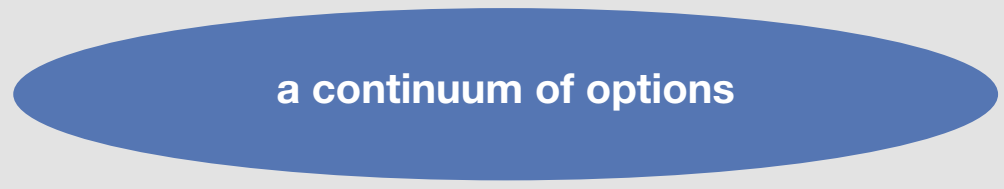

\section{full control by agency}

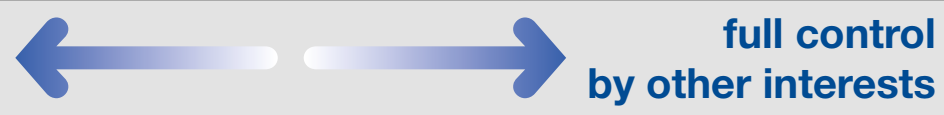

\begin{tabular}{|c|c|c|c|c|c|c|}
$\begin{array}{c}\text { government } \\
\text { sole } \\
\text { decision- } \\
\text { making }\end{array}$ & $\begin{array}{c}\text { government } \\
\text { consultative } \\
\text { decision- } \\
\text { making }\end{array}$ & $\begin{array}{c}\text { government } \\
\text { co-operative } \\
\text { decision- } \\
\text { making }\end{array}$ & $\begin{array}{c}\text { joint } \\
\text { decision- } \\
\text { making }\end{array}$ & $\begin{array}{c}\text { delegated } \\
\text { decision- } \\
\text { making }\end{array}$ & $\begin{array}{c}\text { stakeholder } \\
\text { decision- } \\
\text { making }\end{array}$ \\
\hline
\end{tabular}

state-owned

Shared/co-managed

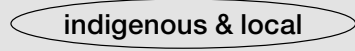

state-controlled

Private/NGO

Figure 2.1 A continuum of options for governance diversity

(Source: Adapted from Borrini-Feyerabend, 1996, p. 17)

Governance responsibilities at local scale include a wide variety of tasks, from taking on full planning and management responsibilities in specific sites for biodiversity conservation, protecting important ecosystem services on which they may depend (e.g., rivers and watersheds, coastlines), helping restore degraded areas in their neighbourhoods, or maintaining localized connectivity conservation needs. Local governance responsibilities also include participating in national and regional planning decisions that may affect them, and having a key role in preparing and implementing local spatial plans within the framework of national plans and processes. Box 2.2 gives an example of one community in Africa taking on the governance role with coastal and marine planning and sustainable use. 
Box 2.2 An ICCA - Kawawana, Senegal, managing planning and implementation

Kawawana (meaning "our local heritage to be preserved by us all") is an estuarine territory where ancient governance and management rules have been revived and have achieved legal recognition by the municipal and regional governments in Senegal. These rules are being implemented by the Governing Board of Association des Pêcheurs de la Communauté Rurale de Mangagoulack (APCRM), a rural group of fishers based in the communities of Mangagoulack. The APCRM represents a collective of resource users who took matters into their own hands when seeing resource degradation in their area by prescribing a zoning system for their local river system.

The figure below shows three categories of resource use: the yellow denotes Zone 1, the zone for subsistence fishing by local villagers; Zone 2, the orange section, is located in the degraded mangrove section and hence allows fishing but without any motorised fishing boats, so as to allow for restoration. Zone 3, marked by the red winding river system is surrounded by healthy and dense mangrove forests and constitutes a strict protected area. The local fishers govern, manage and monitor their own Kawawana, which has dramatically recovered in quantity and quality of biodiversity (fish, dolphins, crocodiles, birds amongst others), whilst providing food security for the local population, estimated to be about 12,000 people of the Diola ethnic group.

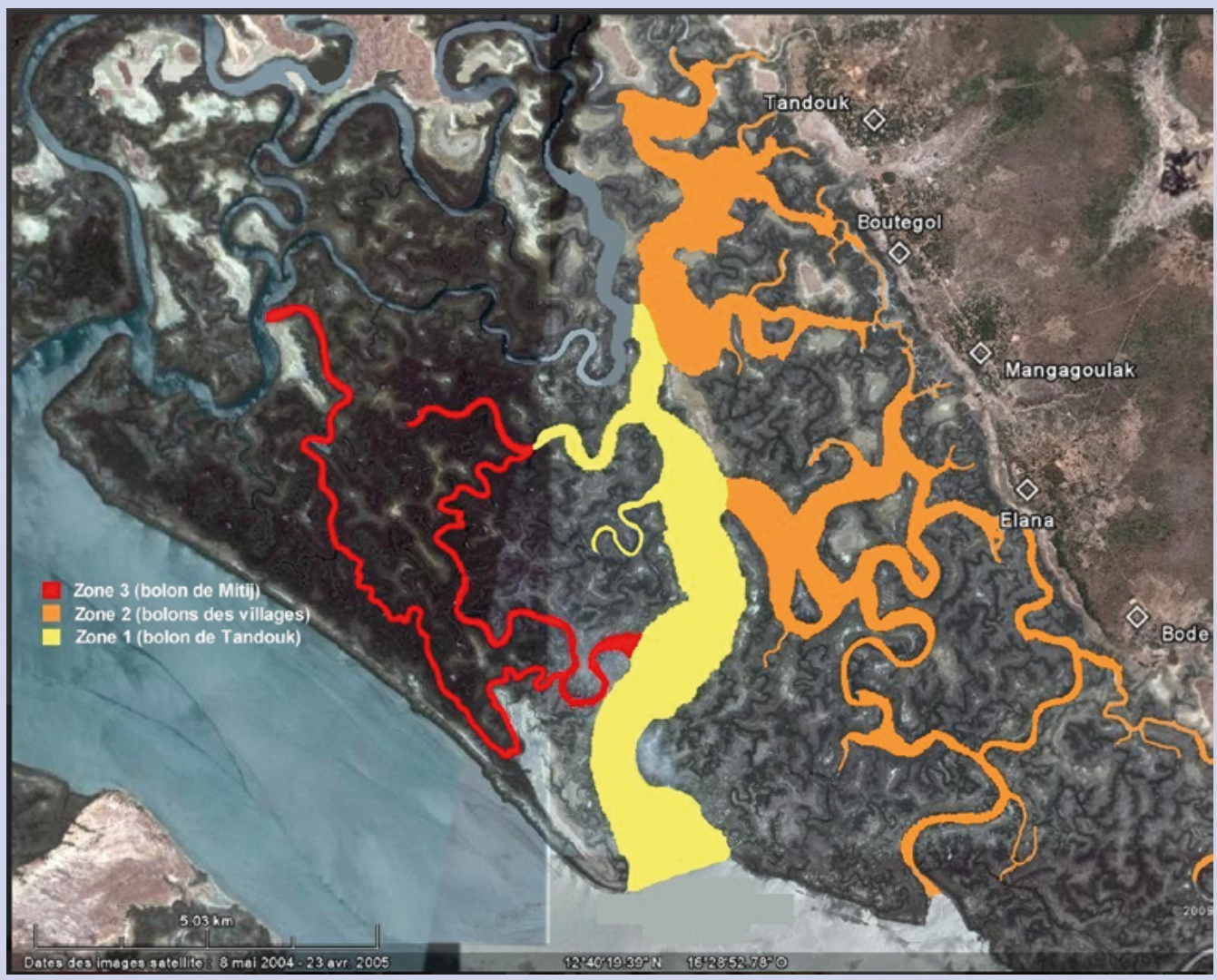

(Source: APCRM (Association des Pêcheurs de la Communauté Rurale de Mangagoulack)) 
There is a significant role for law and policy frameworks for spatial planning to promote and recognize governance diversity options for regional and local scale planning and implementing, consistent with national objectives, goals, and the spatial planning framework. Specific elements should include recognizing a participatory role for indigenous and traditional peoples, local communities, and other stakeholders with land tenure or resource use rights. Procedures for participation should explicitly reference these interests. Both formal mechanisms (advisory committees, implementation committees) and informal mechanisms (direct consultations, social media communications) may be important to consider. Special attention should be given to inputs on environmental conditions of the lands, marine areas, and natural resources currently, their economic and social/cultural values and traditions, and how future development should be planned and managed to secure their long term cultural, social, and economic livelihoods, social equity and justice, conservation and sustainable use of natural resources, climate change adaptation and mitigation needs, and near and long term sustainable development.

Moreover, growth of high tech, including information and communication technologies, as noted above, presents special challenges for governance at the local level. Law and policy should support access to resources and capacity building at the local scale of spatial planning. Not many studies are focused just at a local scale of spatial planning, but rather on urban issues in general. Nevertheless, communities are beginning to perform spatial planning roles different from what they were doing before the growth of information technology. Some observations can be distilled on challenges ahead for communities and stakeholders in spatial planning and governance for biodiversity and climate change at the local scale.

- It is expected that tasks of local authorities and community representatives in spatial planning will continue to increase, with or without necessary resources.

- Promoting and using new technologies, synergies, territorial cohesion and consensus will be important for effective local spatial planning.

- Success of governance will be based on the most appropriate configuration of all actors rather than the privileged role of local government.

- It can be anticipated that the number of local political actors and non-elected authorities participating will increase and local political monopolies may have less dominance.

- In view of international efforts to promote expanded protected area coverage through formal designations of protected areas under different governance types, and to give new recognition to those landowners or rightsholders undertaking 'other effective conservation measures (pursuant to Aichi Target II), the types and numbers of governance actors are likely to increase and be more diverse, with added challenges for collaboration, coordination, and communication.

- Given that in spatial planning for a particular region or village, there will likely be several tiers of authorities (education, health, transport, environment, housing, etc.), the power of local authorities may become more ambiguous and no single one may be able to claim representation of the area in totality. The challenge is to bring together a disparate set of potential participants.

(adapted from Virtudes, 2016) 


\subsection{Key messages}

Especially since the 1990s, advances in international law, science and technology, and governance approaches have triggered efforts by countries to revive and reframe planning systems to better respond to the opportunities and obligations presented. In particular, two global conventions, the CBD and UNFCCC, both concluded in 1992, converged to direct efforts to modernizing spatial planning systems to incorporate biodiversity and climate change objectives. Both conventions and their subsequent decisions contained targets that needed long-term spatial planning. The CBD Aichi Biodiversity Targets actually specified percentages of land and marine space for countries to protected for biodiversity and ecosystem services by 2020. Similarly, advances in science and technology significantly expanded knowledge about natural systems and changing environmental conditions, generating new tools for more efficient data collection, analysis, monitoring, and evaluation of environmental conditions to support spatial planning. Finally, awareness was growing of the many types of governance that could work for sustainable land/sea and resource use and the importance of good governance principles for decision making, including active and meaningful participation. Together these developments helped energize and support efforts to modernize planning systems for comprehensive and long-term spatial planning, including for biodiversity and climate change. 


\section{New elements for integrated spatial planning}

This Chapter highlights elements that are part of the new thinking and reframing of public planning for a country's territorial space in order to be more responsive to $21^{\text {st }}$ century needs that it is confronting, including climate change. Climate change, in particular, has triggered a renewed interest in the need for environmental planning as a key part of the process for achieving sustainable development (see Wilson \& Piper, 2010). The following discussion focuses on elements that are new for many presentday public sector planning departments who traditionally have worked main on technical planning issues such as zoning, mapping, permitting, and building conditions. In many cases these new dimensions to planning may call for new skills, capacities, and collaborations with other departments for success.

\subsection{Long-term planning horizon}

Spatial planning is not about specific proposals to carry out development on specific sites. It's aim is to guide future development. Based on research into inputs such as demographic trends, infrastructure requirements, natural systems and species needs, and geophysical constraints, it strives to lay out which types of new uses or changes in existing uses over land/sea and natural resources should be allowed or prohibited in the near and distant future to achieve sustainability. Also with a view toward sustainability, it may include the principles, criteria, guidelines, and standards that future built development should meet (Lausche et al., 2013).

Because of a longer planning horizon, this tool has the potential to project human needs over time taking into account global change, using scenarios that can be adjusted as new knowledge is gained, and building in precautionary measures that leave core options available even as compatible site management and development proceeds over the near time. Such a process includes the ongoing task of balancing relationships between protected areas, other conservation values (biodiversity, ecosystem services, connectivity), broader landscape/seascape protection and adaptation needs, and human services. The longer term planning focus facilitates flexibility, ongoing data collection and analyses, and scenario revision as needed to support the economic, social, and environmental goals necessary for achieving sustainable development.

Planning literature stresses that spatial planning must evolve quickly to take a more socio-ecological perspective if countries are to achieve sustainable development goals. This means incorporating new planning spaces for biodiversity conservation, ecosystem-based management, and climate change adaption. In terms of process, it means policy integration within and across sectors, coordination across sectors and levels of government, and participation and involvement of stakeholders. National modernization of spatial planning systems also advance international environmental law obligations and policy commitments, as discussed above.

\subsection{Definitions stress integration}

Today, spatial planning is a term without a universal definition across countries or in the literature. A common feature among the various definitions, however, is the emphasis on policy and programme integration, reducing potential use conflicts and working toward sustainable development. In western Europe, a region with a long planning tradition, a guiding document since the late 1990s is The EU 
Compendium of Spatial Planning Systems and Policies (CEC, 1997) provides one of the first definitions of spatial planning which is still used today. For the $28 \mathrm{EU}$ countries, spatial planning means:

the methods used largely by the public sector to influence the future distribution of activities in space. It is undertaken with the aims of creating a more rational territorial organization of land uses and the links between them, to balance demand for development with the need to protect the environment, and to achieve social and economic objectives. Spatial planning embraces measures to co-ordinate the spatial impacts of other sectoral policies, to achieve a more even distribution of economic development between regions than would otherwise be created by market forces, and to regulate the conversion of land and property uses....

Spatial planning encompasses elements of national and transnational planning, regional policy, regional planning and detailed land use planning. National spatial planning includes the broad development frameworks or perspectives prepared to guide spatial development patterns and lower-tier spatial plans. Such perspectives usually include a 'transnational' dimension where they seek to interpret the implications of wider supranational development patterns for the nation. National spatial planning also includes national guidelines or plans which may not themselves have a spatial dimension but which constrain the options of plan makers at the regional and local levels. At this level, both perspectives and guidelines will be closely linked to the social and economic policies of government and will seek to co-ordinate activities across different sectors. (p. 24)

For another take, a 2018 article in the journal Land Use Policy defines spatial planning as "shaping economic, social, cultural, and ecological dimensions of society through 'place making' with a shift towards more positive, integrated, and resource-based contexts" (Allmendinger \& Haughton 2010). The concept was further elaborated by another expert:

"Spatial planning is increasingly oriented towards being an instrument and/or process for resolving conflicting demands on space; it is a means of looking at the spatial dimension of strategic policies with the objective of integrating and coordinating all space-consuming activities within a single geographic territory" (Okele 2015, in Metternicht, 2018).

\subsection{Ecosystem-based approach}

A field of science essential to incorporate in modern spatial planning is ecology and what is being learned about the critical ecosystem-based approach for ecological sustainability. Natural science and biodiversity conservation research have made major strides in recent decades understanding the importance of the ecosystem-based approach. These advances are important for valuing ecosystem services adequately in spatial planning. Ecosystem services contribute to economic well-being and associated development goals, such as the Sustainable Development Goals. They contribute to the generation of income and material goods (e.g., provisioning of food and fiber), and through the reduction of potential costs of adverse impacts of climate change (e.g., coral reefs and mangrove swamps protect coastal infrastructure).

Conservation biology, conservation planning, landscape/seascape ecology, and connectivity conservation are among the key areas of research and growth recognizing the ecosystem-based approach. Much of this progress has involved advances in ecosystem 'science', a field defined as follows:

"the study of inter-relationships among the living organisms, physical features, bio-chemical processes, natural phenomena, and human activities in ecological communities. Within any given area, living and nonliving interact with each other. Together, these things form an ecosystem." (NOAA, 2018) 
Recent technical articles on land use policy recommend that ecosystem science be 'mainstreamed' into spatial planning policy and decision-making for the resulting plans and their implementation to be most effective on the ground. This came through strongly in an article from UK academic and practicing planners as a spatial planning requirement in order to adequately incorporate spatial and temporal aspects of biodiversity processes and climate change resilience (Scott et al., 2018). The rationale is that this will help to improve the way ecosystem services are respected, valued, and protected in planning systems nationally and globally. They further propose that both the ecosystem approach and spatial planning should be rooted in social-ecological systems thinking that crosses environmental, social, economic, political and cultural contexts and sectors.

In this context, they see a potential convergence of definitions and principles and value in exploring mechanisms to facilitate integration and mainstreaming of ecosystem science knowledge flows and exchange within policy and decision-making processes. To support this suggestion, they map the 12 principles of the ecosystem approach according to the CBD against spatial principles defined by the UNECE (see Table 3.1).

\section{Table 3.1 Matching principles of ecosystem and spatial planning approaches}

\begin{tabular}{|l|l|}
\hline Spatial planning principles & \multicolumn{1}{|c|}{ Ecosystem approach principles } \\
\hline $\begin{array}{l}\text { The Governance principles } \\
\text { (e.g., authority, legitimacy, } \\
\text { institutional power, decision } \\
\text { making) }\end{array}$ & $\begin{array}{l}\text { 1. The objectives of management of land, water and living resources are a } \\
\text { matter of societal choice. } \\
\text { 3. Ecosystem managers should consider the effects (actual or potential) of } \\
\text { their activities on adjacent and other ecosystems. } \\
\text { 9. Management must recognize that change is inevitable. }\end{array}$ \\
\hline $\begin{array}{l}\text { The Subsidiarity Principle } \\
\text { (e.g. delegation to lowest level; } \\
\text { shared responsibility; } \\
\text { devolution) }\end{array}$ & 2. Management should be decentralized to the lowest appropriate level. \\
\hline $\begin{array}{l}\text { The Participation Principle } \\
\text { (e.g. consultation; inclusion; } \\
\text { equity; deliberation) }\end{array}$ & $\begin{array}{l}\text { 11. The ecosystem approach should consider all forms of relevant infor- } \\
\text { mation, including scientific and indigenous/traditional and local knowl- } \\
\text { edge, innovations and practices. } \\
\text { 12. The ecosystem approach should involve all relevant sectors of society } \\
\text { and scientific disciplines. }\end{array}$ \\
\hline $\begin{array}{l}\text { The Integration Principle } \\
\text { (e.g. holistic; multiple scales } \\
\text { and sectors; joined up) }\end{array}$ & $\begin{array}{l}\text { 3. Ecosystem managers should consider the effects (actual or potential) of } \\
\text { their activities on adjacent and other ecosystems. } \\
\text { 5. Conservation of ecosystem structure and functioning, in order to main- } \\
\text { tain ecosystem services, should be a priority target of the ecosystem ap- } \\
\text { proach. } \\
\text { 7. The ecosystem approach should be undertaken at the appropriate spa- } \\
\text { tial and temporal scales. } \\
\text { 8. Recognizing the varying temporal scales and lag effects that character- } \\
\text { ize ecosystem processes, } \\
\text { objectives for ecosystem management should be set for the long term. } \\
\text { 10. The ecosystem approach should seek the appropriate balance be- } \\
\text { tween, and integration of, conservation and use of biological diversity. }\end{array}$ \\
\hline
\end{tabular}




\section{The Proportionality Principle (e.g. deliverable viability; pragmatism; best available information)}

The Precautionary Principle (e.g. adaptive management; limits; uncertainty; risk)
4. Recognizing potential gains from management, there is usually a need to understand and manage the ecosystem in an economic context. 9. Management must recognize the change is inevitable.

6. Ecosystem must be managed within the limits of their functioning, 8. Recognizing the varying temporal scales and lag effects that characterize ecosystem processes, objectives for ecosystem management should be set for the long term.

10. The ecosystem approach should seek the appropriate balance between, and integration of, conservation and use of biological diversity,

(Source: adapted from Scott et al., 2018, p. 233, comparing principles from CBD, 2010, and UNECE, 2008)

Underlying this call for mainstreaming and convergence of ecosystem science and spatial planning principles is the significant and ongoing decline in most ecosystems of the world as a consequence of human interventions and actions (e.g., conclusions of the Millennium Ecosystem Assessment, 2005). Efforts to counter this decline have already resulted in global, EU, and national moves to mainstream ecosystem services within policy-shaping frameworks. Examples include national ecosystem assessments, creating new environmental markets for payments of environmental services (e.g., watershed services), integrating ecosystem services into spatial planning to understand ecological and socio-economic trade-offs of developing new areas, and green accounting (valuing natural capital). For a specific example, England recently launched an Ecosystem Approach Action Plan (see Box 3.1) which sets out an approach to shift spatial planning and policy making towards a more holistic and integrated approach based on whole ecosystems.

\section{Box 3.1: England's Ecosystem Approach Action Plan 2018}

England's initiative to develop an Ecosystem Approach Action Plan (EAAP), formally launched in 2018, represents more than a decade of deliberations about ways to incorporate the ecosystem approach into spatial planning. Development of the EAAP, initially released in 2007 and updated in 2010, was led by the UK Department for Environment, Food and Rural Affairs (DEFRA) working with many other departments, partners and stakeholders. The mandate to integrate an ecosystems approach into UK spatial planning was part of the Department's 2010 action plan. The EAAP is now part of the Department's broader 2018 environmental plan, "A Green Future: Our 25 Year Plan to Improve the Environment".

It is worth a brief review of the focus and priorities set forth in the EAAP, as an example of how one country framed its purpose and objectives. The plan sets out the concept and framework of ecosystem services, and describes how this can be translated into "an ecosystems approach" to policy and decision making for all levels of the UK Government. It focused on two main objectives:

- Shifting the focus of policy making and delivery away from looking at natural environment policies in separate "silos" - e.g., air, water, soil, biodiversity - and towards a more holistic or integrated approach based on whole ecosystems

- Seeking to ensure that the value of ecosystem services is fully reflected in policy and decision making in Defra and across Government at all levels.

In addition, it set out five priority areas where progress is needed in order to embed this thinking and approach more firmly into policy and decision making.

- Promoting joined-up working within Defra and the Defra Network to deliver environmental outcomes more effectively

- Identifying opportunities for mainstreaming an ecosystems approach

- Using case studies that demonstrate the benefits of taking an ecosystems approach

- Developing ways of valuing ecosystem services 
- Developing a robust evidence base.

The EAAP is a major UK initiative for implementing the CBD principles and guidance on the ecosystem approach for biodiversity conservation (see https://www.cbd.int/ecosystem/). As an operational goal, the Plan states that the Ecosystem Approach can

help society make better informed decisions about how to balance economic, environmental and social objectives in pursuit of truly sustainable development.... [and] take full account of environmental impacts, by enabling better prioritisation and more efficient use of our resources, and by enabling more effective communication between diverse stakeholders, promoting greater awareness of the value of the natural environment and ecosystem services to a wide section of society" ( DEFRA, 2010, p. 4)

(available online at https://ecosystemsknowledge.net/sites/default/files/wp-content/uploads/Defra\%20 healthy-nat-environ.pdf)

(Research and draft by Jennifer Kelleher, IUCN-GPAP, Programme Officer, Governance, Equity and Rights. 2018)

\subsection{Precautionary approach}

Another key principle for spatial planning is the requirement to apply the 'precautionary approach in all key planning steps, including preparation, management, revision, and implementation. This is necessary because science does not yet fully understand ecological processes and threats to species and ecosystem services over time, nor can scenarios of future climate change impacts be definitive. This principle has been recognized in international law and policy since 1970, and is included in the 1992 Rio Declaration on Environment and Development, principle 15. It should be incorporated as a core decision making principle in domestic law generally and in spatial planning specifically.

The principle provides that where knowledge is limited and there is lack of certainty regarding the threat of a serious environmental harm or unanticipated future threat, this uncertainty should not be used as an excuse for avoiding action to avert that harm. It provides a policy basis to anticipate, avoid and mitigate future threats to the natural environment, instead of not deciding at all. Use of the precautionary approach in conservation and sustainable development decisions is becoming increasingly important today because decisions about core concerns such as biodiversity conservation, ecosystem resilience, connectivity needs, or adaptation options will inevitably deal with uncertainties and complex projections, particularly with climate change, where there are gaps in knowledge.

Some country constitutions recognize the precautionary principle (e.g., Ecuador's National Constitution 2008). Several multilateral environmental agreements on biodiversity conservation also incorporate the precautionary principle in some manner. For example, the CBD recognizes the need for the precautionary principle in its preamble, as follows: "where there is a threat of significant reduction or loss of biological diversity, lack of full scientific certainty should not be used as a reason for postponing measures to avoid or minimize such a threat." The CBD and several agreements under the Convention on the Conservation of Migratory Species of Wild Animals (CMS) (1979) also emphasize the need to apply the precautionary principle with respect to the introduction, spread and control of invasive alien species.

Article 3(3) of the United Nations Framework Convention on Climate Change (1992) states:

The Parties should take precautionary measures to anticipate, prevent or minimize the causes of climate change and mitigate its adverse effects. Where there are threats of serious or irreversible damage, lack of full scientific certainty should not be used as a reason for postponing such measures, taking into account that policies and measures to deal with 
climate change should be cost-effective so as to ensure global benefits at the lowest possible cost.

In order to preserve the marine environment, its ecosystems and biodiversity, the precautionary principle has been included in a number of fishery treaties, among them, the 1995 UN Agreement on Conservation and Management of Straddling Fish Stocks and Highly Migratory Fish Stocks (Art. 5(c) and Art. 6)). That agreement provides in Article 6, "Application of the Precautionary Approach", the following mandate:

1. States shall apply the precautionary approach widely to conservation, management and exploitation of straddling fish stocks and highly migratory fish stocks in order to protect the living marine resources and preserve the marine environment.

2. States shall be more cautious when information is uncertain, unreliable or inadequate. The absence of adequate scientific information shall not be used as a reason for postponing or failing to take conservation and management measures.

3. In implementing the precautionary approach, States shall:

(a) improve decision-making for fishery resource conservation and management by obtaining and sharing the best scientific information available and implementing improved techniques for dealing with risk and uncertainty;

(b) apply the guidelines set out in Annex II and determine, on the basis of the best scientific information available, stock-specific reference points and the action to be taken if they are exceeded;

(c) take into account, inter alia, uncertainties relating to the size and productivity of the stocks, reference points, stock condition in relation to such reference points, levels and distribution of fishing mortality and the impact of fishing activities on non-target and associated or dependent species, as well as existing and predicted oceanic, environmental and socio-economic conditions; and

(d) develop data collection and research programmes to assess the impact of fishing on non-target and associated or dependent species and their environment, and adopt plans which are necessary to ensure the conservation of such species and to protect habitats of special concern.

This extensive attention to the precautionary approach in marine waters and the Agreement's close relation with the UN Convention on the Law of the Sea (UNCLOS) (1982), is considered to carry over to UNCLOS even though that Convention, concluded much earlier, does not explicitly mention the principle. Article 4 of the Agreement is clear about its UNCLOS roots when it provides that the Agreement shall be interpreted and applied in the context of and in a manner consistent with the Convention.

In 2007, IUCN published Guidelines for Applying the Precautionary Principle to Biodiversity Conservation and Natural Resource Management (see https://www.iucn.org/sites/dev/files/import/ downloads/In250507_ppguidelines.pdf). 


\subsection{Conservation planning as an integral part}

Conservation planning, in all its different forms, is now both an expected and a valued practice in NGOs and government agencies alike, and like any discipline, conservation planning needs to continuously improve to be effective (see, Groves \& Game, 2016).

Conservation plans can be made for a wide range of conservation purposes. As concluded in the IUCN concept paper on connectivity conservation law (Lausche et al., 2013), sometimes these plans do not have a detailed legislative basis and, where they relate to land/marine space outside protected areas, they often do not have direct legal implications for uses that landholders or rightsholders are currently making of that space or resources, or the future development that they might carry out. Under these circumstances, ... "it is crucial that conservation plans and policies, on the one hand, and land use [spatial] plans, on the other, are adequately integrated so that they do not conflict with one another... As a policy goal, modern land use planning legislation should require land use plans to be consistent with the provisions of conservation plans (Lausche et al., 2013, pp. 107 and 116).

At the policy level, governments commonly incorporate biodiversity conservation in their broad policy statements and express general strategies and commitments. Increasingly, such policy statements also link biodiversity to strategies for climate change adaptation and connectivity conservation. Even though these broad policy statements in themselves are not legally binding, they also have a valuable role in requiring government agencies at different levels, including land use and spatial planning agencies, to pursue the stated objectives and strategies.

As the sciences have continued to gain a more holistic understanding of the natural and environmental resources underpinning human societies, there is growing acceptance of the need for conservation plans to be integrated into modern spatial plans, and for this to be grounded in law. In virtually all countries, some aspect of conservation planning already exists, at a minimum for specific threatened species' habitats, valued cultural sites (including World Heritage Sites), and economically valuable ecosystems. These plans reflect many different law and policy mandates and frequently are the responsibility of different sectors. They include protected areas plans (terrestrial and marine), watershed management plans, water resource management plans, forest and fisheries sustainable use plans, coastal conservation plans, and increasingly connectivity conservation plans for specific ecosystems or threatened species.

At the species level, guidance on species conservation planning is a new initiative of the IUCN Species Survival Commission (SSC). This is complementary to other IUCN initiatives with global databases and guidance including through the database of Key Biological Areas, Red List of Threatened Species, Red list of Endangered Ecosystems, and Green List of Protected areas discussed in Chapter 2.2.3 above. According to the new guidance on species conservation planning, any such Plan or Strategy should include the following elements (see IUCN-SCC, 2017, p. 2):

- It should start with a high-level question such as 'What do we want for this species within so many years?' and then progressively work down in terms of time horizons and detailed answers to the question, ending up with the tactics required to implement the strategy.

- It must involve the full range of organisations and individuals that have interests in the species and its habitat.

- A strategic approach should include the social, political and cultural environments in which conservation actions will be taken, acknowledging that the most effective interventions for species may depend on the activities and behaviours of local people. 
- A strategic approach explicitly acknowledges the dynamic cycle of learning by doing and then adapting in pursuit of the longer-term ambition, in contrast to a one-off set of responses or actions.

- A strategic approach includes consideration of the resources, risks, priorities and other aspects of implementation.

The IUCN species guidelines organize the text of some 132 pages around an illustration of a species conservation cycle, which is copied below for its relevance generally to conservation planning steps (see Figure 3.1 below).

\section{The SSC Species Planning Conservation Cycle}

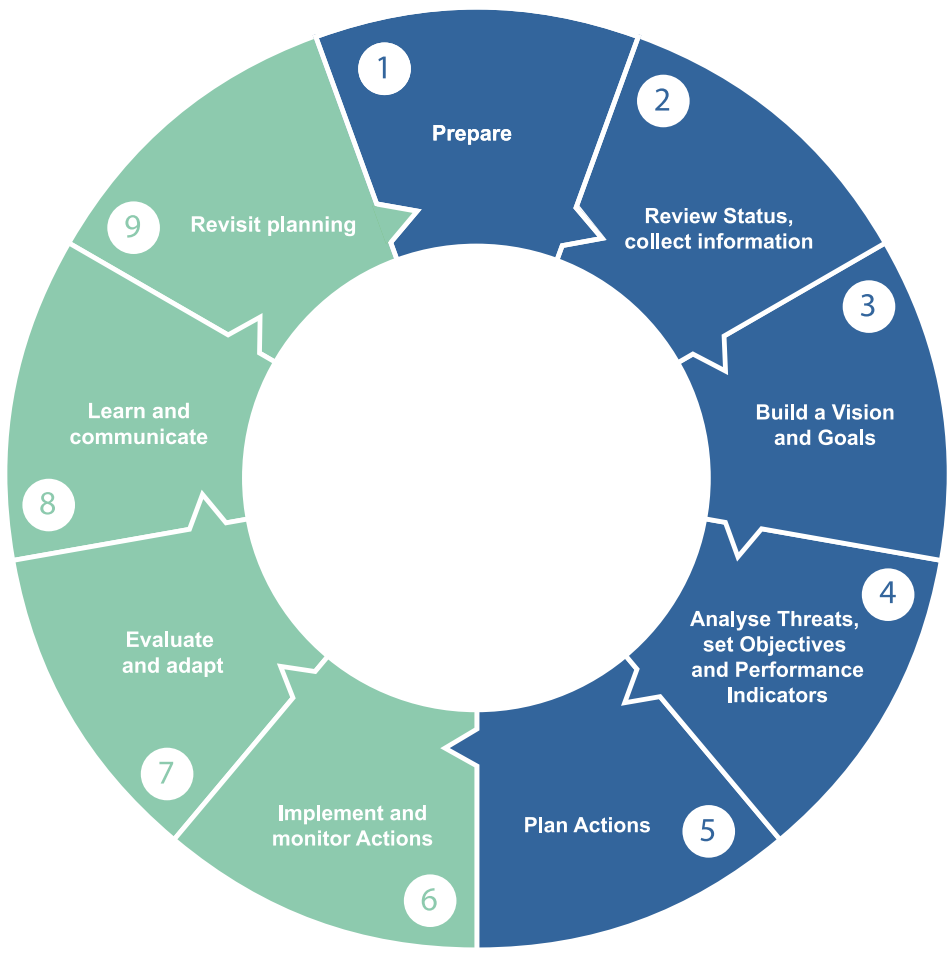

\section{Figure 3.1 IUCN Species Planning Conservation Cycle}

(Source: IUCN-SSC, 2017, p. 4) 
At a broader strategic planning level, recent national planning initiatives have endeavoured to be comprehensive in integrating conservation and development. These initiatives have been promoted, in various ways, through international policy and law, as well as through development assistance and pursuing development goals. While not legally binding in themselves, examples include national biodiversity strategy and action plans, environmental action plans, biodiversity conservation plans, climate change adaptation plans, and strategic environmental assessments.

Because of the many applications possible, conservation planning is not easily defined. Authors of a 2016 book on conservation planning offer the following:

Conservation planning is a systematic process that is primarily focused on identifying, developing, and implementing strategies to conserve specific features of biological diversity, the ecological processes that sustain this diversity and the ecological (ecosystem) services that are provided by it (Groves \& Game 2016, p. 11).

A 2009 CBD technical report on biodiversity and climate change acknowledged that conservation strategies need to be flexible in order to change and adapt as ecosystems are more and more affected by climate change. Adaptation will need to involve not only reducing the impacts of climate change on biodiversity but also assessing and, where necessary, adjusting traditional conservation practices and targets in order to reflect changing conditions. That report concluded with guidance important for countries to keep in mind when reviewing and strengthening, as needed, spatial planning, conservation, and climate change laws and policies related to ecosystem functions and services:

The aim of conservation strategies in the future will need to include minimising the loss of biodiversity and to maintain ecosystem services in the face of climate change. However, conservation and adaptation strategies that are flexible and robust in light of uncertainty about the magnitude, direction and rate of climate change will be needed. Strategies that facilitate the autonomous transformation of ecosystems in response to changing conditions, such as adaptive management and scenario planning, are most likely to maintain biodiversity and ecosystem functioning. (CBD, 2009, pp. 34-35)

Analysis of future conservation planning considerations has highlighted two specific change factors. In a 2007 article by Pressey and colleagues on "conservation planning in a changing world", the authors give a spatial planning perspective:

Conservation planning is the process of locating, configuring, implementing and maintaining areas that are managed to promote the persistence of biodiversity and other natural values. Conservation planning is inherently spatial. The science behind it has solved important spatial problems and increasingly influenced practice. To be effective, however, conservation planning must deal better with two types of change. First, biodiversity is not static in time or space but generated and maintained by natural processes. Second, humans are altering the planet in diverse ways at ever faster rates. (Pressey et al., 2007) (emphasis added)

As emphasized in that article, modern spatial planning must take into account: I) biodiversity processes, and 2) the dynamic nature of threats, not only from natural events but also due to activities of government sector and human activities. This is because sites identified as biodiversity-rich today, likely in protected areas, will become outdated as climate change and human pressures, among other threats, force adaptation or result in extinction. Biodiversity has both biological and physical aspects, from molecular to global in scale; processes involved in survival include movement of individual organisms, recolonizations, seasonal migrations, and adjustment for predation and species' redistributions due to a changing climate. 
Plans must recognize and protect the spatial requirements of these processes and the dynamic threats that are likely to arise. Otherwise, many species and ecosystem functions will be disrupted or cease altogether. Already, major threats come from such human actions as deforestation, damming of rivers, overharvesting of top marine predators, introduction of invasive species, and reduction of connectivity and species population sizes through habitat fragmentation. Many threats come from non-environmental sectors (e.g., transport, energy) which then require ongoing communication between such sectors and the Planning Authorities. Without remedial action, the consequences are loss of species and reduced evolutionary potential of many that remain. (Pressey et al., 2007, p. 583)

Groves and Game in their 2016 book on conservation planning offer some principles and standards for modern conservation planning. In bullet form these are (adapted from text, pp. 24-28):

- Biodiversity conservation was once heavily focused on conserving species. The Millennium Ecosystem Assessment (2005) awakened the conservation community to the importance of conserving ecosystem processes and services and the benefits these processes can provide to people.

- Scientific assessments are important to undertake about the state of knowledge in order to inform policy through science regarding the planet's biodiversity, ecosystems and the benefits they provide to people, as well as the tools and methods to protect and sustainably use these vital natural assets. This is a global theme promoted particularly by the Intergovernmental Science-Policy Platform on Biodiversity and Ecosystem Services (IPBES), an independent intergovernmental body, established by member States in 2012, parallel to the IPCC for climate but in this case for biodiversity.

- Conservation plans should answer two major questions: 1) where on the ground or in the water are the most important natural places to safeguard in some conservation form to achieve the goals and commitments of the country to sustainable development and the CBD Strategic Plan, and 2) what are the strategies, interventions, actions, and threats to address over the near and long term to best implement and sustain those safeguards.

- Establishing corridors between conservation areas and Key Biodiversity Areas has long been regarded as an important action in fragmented habitats or semi-natural/natural landscapes/seascapes that could face degradation.

- Important components of modern conservation planning:

- multi-objective planning - working with other sectors, developers, productive landscapes/ seascapes (e.g., agricultural lands, forest plantations, fishing zones, even urban settings),

- integration of spatial and strategic planning - the toolbox for conservation has broadened and planning today must include what specific actions need to be taken in the specific place identified as a conservation priority; it is not sufficient only to indicate the place as a priority without indicating for what conservation action,

- ecological, social, economic, and political science all make important contributions to successful conservation projects and they all need to be thoughtfully considered in the planning process,

- ecosystem protections should operate within social and economic systems that are embedded in those ecological systems because there will be important linkages and feedback loops between them, 
- evaluation of alternative actions and strategies, including use of scenarios, facilitate considering a range of possible actions that could help achieve the desired outcomes; important to document with some evidence why one course of action may be preferred over another,

- undertake risk analysis from a planning perspective, risks and uncertainties should influence how one perceives expected benefits and costs of a conservation action,

- close planning-implementation gap: do a better job in conservation planning of actually addressing strategic planning and implementation of conservation actions.

In the context of a country's policy and law framework for spatial planning, it is important that conservation plans and policies are legally required to be recognized as an integral part of spatial plans. This is essential for certainty and consistency across programme objectives and for secure investments. In addition, conservation planning (including protected areas and species planning) needs to be guided by best available scientific information about the changing environment, risks, uncertainties, and the socio-ecological system involved. Law and policy frameworks also may give guidance on operational procedures for using information and monitoring change, including using geo-spatial data, and applying flexibility to adapt to new information and developments.

\subsection{Key messages}

Distinct elements emerging for modern spatial planning differentiate this type of planning from more conventional land use/urban planning approaches. These relate to principles and processes that go beyond the public sector planner's typical technical role to oversee zoning and permitting for specific development proposals. Core features include a longer-term planning horizon broken down into near-term (roughly 10-25 years), medium-term (30-50 years), and long-term (75-100 years, mainly to adequately address climate change). While there is no agreed definition for integrated spatial planning, another core feature that all definitions share is the need for integration across policies and plans at all levels of government and all sectors at each level. The use of the ecosystem-based approach also is a required element for effective spatial planning, particularly to reflect biodiversity and climate change adaptation needs. The precautionary principle is yet another core element of spatial planning analysis and decision making; it is essential for dealing with uncertainties and risks that are inevitable when planning farther into the future, especially for climate change. Finally, spatial planning incorporates conservation plans of all types and also reconciles other formal or informal ('soft') plans that have spatial aspects, including climate change adaptation plans for building resilient ecosystems. 


\section{Benefits for biodiversity and ecosystem resilience}

This chapter highlights key benefits that flow from spatial planning approaches and plans that incorporate biodiversity conservation and spatial needs of natural systems and species for adaptation to and mitigation of climate change, including measures to build ecosystem resilient.

A number of generic benefits could flow from modernized spatial planning beyond what conventional land use planning practices have traditionally provided. These include to -

- bring a country in line with international, regional, and national law and policy on climate change and biodiversity, and strengthen cooperation with international organizations and neighboring states

- harmonize approaches to future development for outcomes that have benefits for both climate change and biodiversity

- address land/marine spatial and resource use conflicts

- provide resilient to climate change risks

- address and support ecosystem services

- encouraging longer-term strategies for future growth management and coordination, and investment

- provide the spatial dimension for improved integration across sectoral plans and activities (horizontal coordination), especially with those having significant geographic impacts (e.g., transport, agriculture, environmental policies)

- strengthen links and coordination across levels of government (vertical coordination), using principles of subsidiarity (giving management responsibility to institutions closest to the resources/issues at stake) and reciprocity (mutual recognition of privileges between levels of government)

- improve engagement with stakeholders and the public, especially at the local level

- promote balanced sustainable development as a facilitator of growth rather than as a barrier, and

- provide a tool for resolving disagreements around development in advance of the development.

\subsection{Advancing CBD strategic goals for biodiversity}

Biodiversity offers both important direct and indirect benefits to people and nature through the inherent value of species and habits, biological products, and ecosystem services. Spatial planning can explicitly safeguard these biodiversity benefits and values in landscapes/seascapes in rural, urban, coastal, inland, and marine environments. Working in partnership with relevant sectors such as water, infrastructure, and development, spatial planners can play a vital role in enabling protection of critical species habitats, ecosystems, and connectivity needs using many tools that already exist, including Strategic Environmental Assessment (SEA), Environmental Impact Assessment (EIA), and other appropriate assessments (AA). These measures, among others, advance the CBD's Strategic Goals. 
Modern spatial planning also expands spatial analysis to better encompass long-term biodiversity processes and dynamic threats which may be direct or indirect. It uses a three-pronged approach to space planning, looking at: 1) sites and networks; 2) wider landscapes/seascapes; and 3) still broader ecosystems spatial coverage (rivers, coasts, mountains, drylands, prairies, coral reefs, etc.). Spatial planning, with this broad scope, helps maintain the quality of land, air and water and the role of wetlands in flood mitigation, thus contributing significantly to people's quality of life, health, and well-being.

Spatial planning also must be concerned with re-establishing and conserving ecosystems, including ecological networks, as well as wetlands and water courses which form part of such networks. It also must take into account connectivity needs of protected areas and species. In order to achieve these objectives, various ecological elements (such as semi-natural areas, water resources) or derelict industrial sites and brownfields may need to be identified for restoration or for buffering so as to reduce further environmental damage. See Box 4.1 on how the Netherlands is strengthening its ecological networks through its spatial planning strategy.

\section{Box 4.1 The Netherlands National Spatial Strategy and Ecological Networks}

In the Netherlands the nature, policy and process of spatial planning and its interactions with the ecological networks have been very much influenced by history, physical and natural characteristics of the country's economy and its population. Some important features that have affected the nature of spatial planning are: the physical geography of a low lying country, centuries of battle against rising water, high population density, limited space and an economy based on services and transportation.

The need to protect nature by devising a national ecological network of connected protected areas arose in the 1980s and was officially introduced in the Nature Policy Plan in 1990, before the European Union Habitats Directive was adopted and integrated into Dutch policy.

In 2012, a law was enacted as part of the National Policy Strategy for Infrastructure and Spatial Planning (Structuurvisie Infrastructuur en Ruimte, SVIR) to set up a national network of wildlife habitats within the frame of spatial planning. These national ecological networks (NEN), the name now changed to 'Natuurnetwerk Nederland' (NNN), are an interconnected physical network of protected areas across the Netherlands.

Provincial governments in the Netherlands hold decision making powers for land use planning. In 2013 they adopted 'Natuurpact', an agreement setting out goals and action commitments for the ecological networks to the year 2027. The ecological networks have multiple functions, including but going beyond conserving and enhancing biodiversity, to being used as a creative tool by planners for such ecosystem services as water buffering for flood control. The integration of spatial planning and ecological networks signals the clear step towards finding nature based solutions via multifunctional land use, and embedding protected areas as an ecological network into the broader landscape.

For the latest reports on the NNN, please access the English language pages of the Government of the Netherlands at: https://www.clo.nl/en/indicators/en1307-new-ehs-acquisition-and-development . For more information on the history and law and policy frameworks for spatial planning and ecological networks in The Netherlands, see "SPEN - Interactions between Policy Concerning Spatial Planning and Ecological Networks in Europe Country, Study for the Netherlands. 2008. European Centre for Nature Conservation, available at: http://www.ecologicalnetworks.eu/documents/publications/spen/NetherlandsSPENreport.pdf

(Source: Contributed by Jennifer Kelleher, IUCN-GPAP, Programme Officer, Governance, Equity and Rights. 2018)

\subsection{Building resilience and adaptation for climate change}

A key benefit of modern spatial planning is the measures it can provide through plan design and implementation to directly help species and ecosystems build resilience to climate change. This 
can be done through measures that protect on-site biodiversity and conservation planning and management, measures that control negative impacts from human activities, and measures to safeguard areas of future importance for biodiversity and ecosystems to adapt to climate change. These measures benefit communities as well by supporting quality of life and sustaining ecosystem services essential for human health and well-being.

Spatial planning that conserves natural terrestrial, freshwater and marine ecosystems and restores degraded ecosystems (including their genetic and species diversity) is essential for the overall goals of the UNFCCC because ecosystems play a key role in the global carbon cycle and in adapting to climate change, while also providing a wide range of ecosystem services that are essential achieving the UN Sustainable Development Goals. (For an extended discussion on this, see CBD, 2009, pp. 8-12.)

Integrated spatial planning processes also can advise on and identify priority areas (vulnerable coastlines, estuaries, etc.) needing specific climate change adaptation action plans for biodiversity and ecosystem resilience. Once produced, such plans should incorporate those findings into local spatial plans as a guide to local land/marine use and development, as well as the high-level spatial planning processes and plans at regional, provincial, or national level.

Integrating adaptation planning for climate change into existing practices, including overall spatial planning, and involving all interests and governance levels benefits the collaboration and harmonization of the various decision-making processes. This is a conclusion rated with high confidence in the most recent IPCC report and is worth noting here for its compact description of key factors and interests that need to be taken into account in the adaptation process:

Adaptation planning and implementation at all levels of governance are contingent on societal values, objectives and risk perceptions. Recognition of diverse interests, circumstances, social-cultural contexts and expectations can benefit decision-making processes. Indigenous, local and traditional knowledge systems and practices, including indigenous peoples' holistic view of community and environment, are a major resource for adapting to climate change, but these have not been used consistently in existing adaptation efforts. Integrating such forms of knowledge with existing practices increases the effectiveness of adaptation."

(IPCC, 2014, p.19)

Finally, integrated spatial planning approaches and objectives facilitate addressing climate change mitigation and adaptation together in the spatial plan and proposing actions that have dual benefits. Using an ecosystem approach, spatial plans can help guide future development of urban and periurban areas, degraded areas, undeveloped areas, or specific land/sea uses to advance carbon sequestration. This could include application of special green or green-blue infrastructure for urban or rural areas. Areas requiring special climate change adaptations because of current or projected negative impacts (e.g., flooding from extreme rains, sea level rise, drought, changing vegetation covr or mix) could be given options on adaptation measures that also advance mitigation (new ground cover, sea grass beds, etc.).

\subsection{Integration of conservation plans and other sector plans}

At many different government levels, from national and regional to provincial, local, community and neighborhood levels, there are likely to be existing plans with spatial dimensions and impacts covering broad land use and urban interests as well as specific interests, e.g., related to protected areas, forests, watersheds, fisheries, biodiversity, coastal areas. Most government sectors (e.g., energy, mining, agriculture, fisheries, urban affairs, health, housing, commerce, transportation) have 
space-related responsibilities and associated planning requirements that include elements directly or indirectly affecting biodiversity and ecosystems at various levels. These plans are generated from different sectors guided by different ministries or departments. Integration and harmonization of these many plans and policies reinforces common goals, reduces conflicts and redundancies, ensures more efficient use of existing resources, and advances efforts for sustainable development. The important thing for biodiversity is to have clarity about what aspects of other ministerial planning responsibilities are likely to impinge on biodiversity and, flowing from that determination, what information about biodiversity they should consider in their respective plans. Collaboration across parts of government is needed to do this.

The integration of other plans and policies, including protected area and connectivity, policies, into modern spatial plans and policies provides a new opportunity to ensure full incorporation of conservation-related plans and policies into national spatial plans and policies. This includes recording on spatial plans all designated or recognized conservation areas. Under the IUCN conservation system, this would include formally designated protected areas (categories I through $\mathrm{VI}$ ), other conservation areas formally recognized as part of the conservation system even though they may not be formal protected areas under protected areas law, and internationally recognized areas such as RAMSAR wetland sites and biosphere reserves. Such conserved areas may have a variety of governance types (community, indigenous and traditional, private individual, corporation, co-management).

Additional conservation categories to reflect in a modern spatial plan include the new conservation entity called "Other Effective Conservation-based Measures" (OECMs) currently being defined by IUCN to satisfy Aichi Target 11 as areas with sufficient protection to be counted as part of the country's territorial coverage for biodiversity conservation. "Areas for Connectivity Conservation" (ACC) is another emerging conservation concept still being developed by IUCN to reflect special spatial areas serving connectivity needs of biodiversity, ecosystems, and species evolution.

There are particularly important benefits that could flow from more integration and coordination of spatial-related policy with other policy and programme sectors (e.g., water, transport, agriculture, tourism, fisheries, etc.). Such action could help alert planners and developers in these sectors to critical habitat or ecosystem services in order to prevent fragmentation of habitats, degradation or loss of ecosystem functions from other developments as well as climate change. (See an elaboration of these issues through country case studies in Piper et al., 2006.)

\subsection{Protecting connectivity for species and ecosystems}

Many added benefits flow from the role integrated spatial planning can play to identify and protect connectivity conservation needs of valued species and ecosystems within countries and in transboundary situations. In particular, these spaces may not already be within the formal protected areas system or recognized conservation areas but still require some special management safeguards to secure connectivity functions. These should be reflected in the spatial plan processes and resulting plan. Not all spatial areas serving connectivity needs will meet the criteria for a protected area. Alternatively, it may not be the preference of landowners or rightsholders of the property to take that course. The planning region may still have many important conservation spaces or spaces with special private or community status for conservation, e.g., conservation easements running with the land or applicable to land/sea resource use rights, or traditional or customary rights of use that have passed through many generations. These special designations need to be indicated in spatial plans. 
In addition, an essential role of spatial planning is to identify potential corridors and likely species range shifts due to climate change, in both horizontal and altitudinal space. This may include fragmented areas that need restoration for connectivity needs. This information is particularly valuable to help policy-makers, planners, and practitioners coordinate policy and operations to minimize further damage in the near term and include needed restoration actions to future plans and budgets.

To assess the value of a particular space for purposes of connectivity, IUCN conservation practitioners work with four main types of connectivity: landscape/ seascape, habitat, ecological connectivity, and evolutionary process connectivity. Table 4.1 elaborates these types:

\section{Table 4.1 Four types of connectivity}

\begin{tabular}{|l|l|}
\hline Type & Description \\
\hline $\begin{array}{l}\text { 1. Landscape/seascape } \\
\text { connectivity }\end{array}$ & $\begin{array}{l}\text { A human view of the connectedness of patterns of vegetation cover } \\
\text { within a landscape/seascape. }\end{array}$ \\
\hline 2. Habitat connectivity & $\begin{array}{l}\text { The connectedness between patches of habitat that are suitable for } \\
\text { a particular species; habitat patches could be quite localized, region- } \\
\text { al, continental or even global in scope for migratory species such as } \\
\text { some birds and marine mammals. }\end{array}$ \\
\hline 3. Ecological connectivity & $\begin{array}{l}\text { The connectedness of ecological processes across many scales of } \\
\text { air, water, and land, includes processes relating to trophic relation- } \\
\text { ships, disturbance processes and hydro-ecological flows. }\end{array}$ \\
\hline $\begin{array}{l}\text { 4. Evolutionary process } \\
\text { connectivity }\end{array}$ & $\begin{array}{l}\text { Natural evolutionary processes, including genetic differentiation and } \\
\text { evolutionary diversification of populations, that need suitable habitat } \\
\text { on a large scale and connectivity to permit gene flow and range ex- } \\
\text { pansion - ultimately evolutionary processes may require the move- } \\
\text { ment of some organisms over long distances; an increasingly impor- } \\
\text { tant function in a period of global change, including climate change. }\end{array}$ \\
\hline
\end{tabular}

(Source: adapted from Worboys et al., 2010)

\subsection{Key messages}

Modern spatial planning provides important direct and indirect benefits to biodiversity conservation through measures that safeguard biodiversity values and ecosystem services in landscapes/ seascapes, and in rural, urban, coastal, inland, and marine environments. Working in partnership with relevant sectors such as water, infrastructure, and transportation, spatial planners play a vital role in enabling long-term protection of critical species habitats, ecosystems, and connectivity needs ri advance the CBD's Strategic Goals. A key benefit of modern spatial planning with climate change are the long-term safeguards it can provide through plan design and implementation to directly help species and ecosystems build resilience to climate change and sustaining human well-being. Spatial designations can protect on-site biodiversity and conservation planning and management, control negative impacts from human activities, safeguard areas for connectivity and for adaptation of biodiversity and ecosystems to climate change. Finally, spatial planning generates a process for integration of conservation plans and other sector plans. 


\section{Challenges}

The overarching challenge for integrated spatial planning is how to modernize conventional planning systems to be able to respond to $21^{\text {st }}$ century needs and commitments toward sustainable development goals. The literature indicates many specific challenges that will play out in unique ways in different countries according to their legal systems, social and political goals, environmental priorities, and overall capacities and skills. Key challenges are highlighted below. The points are mostly distilled from the various issues discussed above that need consideration for modern spatial planning. (For further elaboration, see, e.g., Wilson and Piper, 2010; Stead and Meijers, 2009; and Wilson and Piper, 2008.) The challenges are clustered under law/policy, institutions, implementation, and technical capacities, although these clusters are very much inter-related.

\subsection{Law and policy}

a) Many different laws and policies across sectors and government layers. Among the greatest challenges facing policy makers, administrators, and practitioners is understanding the complexity of the various polices and legislative directives in different sectors and government levels that may be important for spatial planning that includes biodiversity and climate change objectives.

In addition, biodiversity and climate change will have their own laws and policies that are likely to be dealt with separately, sometimes within different ministries. While conservation may have a relatively long-standing foundation of legal instruments, climate change policies and laws are likely to be more recent. Most countries started with mitigation; there is much less experience with adaptation. Adding to these instruments is the cluster of sector policies and laws, again typically treated separately and under different ministries, that have spatial planning responsibilities specifically to support their sector.

To address the three-way policy integration of planning, biodiversity and climate change requires research and harmonization of a numerous policy and law instruments. This will increasingly involve sub-national levels, especially in federal and decentralized systems, as provincial and local entities exercise more authority over site-specific planning to operationalize national policy.

b) Many plans or planning processes not legally binding, outdated, or unevenly applied. As a general rule, spatial plans in a particular country should have legal standing to give consistency and certainty to developers and planning authorities making the planning decisions. Where spatial plans are made and implemented according to processes and rules set out in legislation they are legally binding. In many countries, however, spatial plans may simply be statements of broad policy (in one or more documents) with limited legal consequences; sometimes these are called non-statutory plans (see, Lausche et al., 2013, pp. 105-106). In other cases, there may be a continuum of types of plans, at one extreme some setting a vision and broad objectives, and at the other extreme containing detailed, legally binding provisions about what types of development can occur in which areas. Often there will be a hierarchy of plans - at national, regional and local level - with a requirement for plans lower in the hierarchy to be consistent with the objectives and constraints set out in the higher.

Even where plans are statutorily-based, in many legal settings proposals that conflict with the plan may be approved with or without conditions. The relationship between planning pro- 
fessionals and the law often is an uneasy one because plans may restrict the discretion that planners like to have and may impose constraints not only on the proponent but on the planners who advise on decision-making under the plan. Political pressure for a planner to advice a certain way frequently may come into play, especially with major development proposals, whether on land or sea.

c) Existing tools are not being fully utilized: This is a big opportunity that in so many instances is not fully appreciated or used. All countries have some law and policy instruments that could be used, revived, or adapted to support modern spatial planning and address biodiversity, climate change, and connectivity needs. This message was emphasized throughout the IUCN companion book, 'Law and Connectivity Conservation - a Concept Paper' (Lausche et al., 2013). However, making full use of existing law and policy instruments requires a good understanding of what is available in the legal system and how it might be applied or interpreted to respond to today's needs. Instead, many new planning efforts seem to want to start afresh. For example, many countries preparing the CBD-required National Biodiversity Strategy and Action Plans (NBSAPs) with support from UNDP do not give much attention to use of existing law and policy instruments. One implication is that important NBSAP commitments may not be adequately and timely implemented because new laws must first be enacted, a wait that may extend into years.

Among the most common existing legal tools from which to build better spatial planning processes for biodiversity and climate change are conventional land use/urban planning laws (in some countries still called 'town and country' planning laws). While not ideal for meeting modern needs, they are a starting point, and may be supplemented with existing conservation laws, as well as master plans, municipal strategies, and 'soft' plans prepared pursuant to particular international obligations or local needs. There also most likely will be authority to do SEAs and EIAs, as well as authority to impose conditions on permits and new licenses for development of mining, energy, ports, or other major site-specific investments to safeguard the health and safety, control pollution, and protect the broader public interest.

\subsection{Institutional}

a) How governments operate. Bureaucratisation and fragmentation of government represent key challenges for policy integration. There is a trend in many countries for more decentralization, delegation and devolution of responsibilities to local levels and more use of contracts with quasi-governmental corporations or private companies to perform tasks previously undertaken directly by government agencies. In addition, creating several bureaucratic steps in approval processes, many carried over from former conventional land use plan procedures, may hinder innovation and communication.

Fragmentation means that more actors are involved in different sectors and levels of government. There may be contradictory mandates and goals. Contracts with outside entities are not likely to including responsibilities for coordination across programmes or sectors. With contractors working in multiple assignments and institutional arrangements at greater distances between themselves and government supervisors, there may be less ability to identify cross-sector impacts or impacts across levels of government. This suggests that an important tool to help with policy integration for spatial planning may be adding provisions to government contracts with quasi-government or private entities that require regular consultation and co- 
ordination with supervisors on issues, especially those that may cross sectors of government layers.

b) Conflicts between different plans and interests. At the political level, there may be difficulties building consensus on vision, priorities and interventions going forward with future development as it needs to be reflected in spatial planning. Almost always there will be some unequal balance of power between sectors and differences in time-scale of policies and programmes across sectors and government layers. These factors may present substantial challenges for negotiations and implementation. There also may be relatively poor contacts between sectors and inconsistent goals that make interactions and trust more difficult.

c) Common institutional barriers. Most governments face challenges with virtually any initiative to update core policies in the course of normal business (in contrast to crises, when rapid change may be required). So as not to give the impression that spatial planning modernization is immune from these common challenges, some of the main generic challenges for effective governance are noted in bullet form here:

- addressing excessive layers of government, complex regulation and compartmental aspects,

- need for adequate enforcement mechanisms; legislation is not enough alone,

- adequate financial and technical support to coordinate human activities,

- capacity of local and regional administrations to have a strong role in spatial planning and preventing and resolving spatial conflicts,

- need for accessible, coordinated, understandable and relevant sources of data and knowledge for effective long-term spatial planning, including for biodiversity and climate change.

\subsection{Implementation}

a) Planning horizons too short. For purposes of future development planning and implementation, and particularly for climate change, the planning horizons of most existing plans and capacities are too short (e.g., 5-10 years). As discussed above, one of the essential features of modern spatial planning is to take a more strategic and longer planning horizon to cover infrastructure and building projects which may have a life of 75-100 years or so. Increasingly, there is consensus that this must include adequately incorporating climate change projections to 2100 for long-term social and economic investments and for adaptation, and always updating scenarios based on the latest IPCC report.

b) Constraints to incorporating needed measures for climate change adaptation. Constraints can interact to impede adaptation planning and implementation of measures to build ecosystem resilience in the face of climate change. Common constraints on implementation arise from the following: limited financial and human resources; limited integration or coordination of governance; uncertainties about projected impacts; different perceptions of risks; competing values; absence of key leaders and advocates; and limited tools to research, monitor and evaluation adaptation effectiveness. (see, IPCC 2014, p. 19)

c) Implementation gaps. Gaps are likely to exist in many countries between the situation on the ground and the desired situation in policy and in plans, even where a planning system is in place. Implementation of planning processes that effectively incorporate biodiversity and 
climate change issues may be spotty or not fully adhered to for some types of development or particular developers, as noted above. Moreover, existing programmes are often insufficiently organized to address common issues effectively, particularly those with a strong cross-cutting nature (e.g., climate change, biodiversity loss). Achieving implementation of integrated policies is dependent on a multitude of different types of factors such as financial, capacities and skills, social and cultural values, governance, and political will; and a multitude of different types of actors from individuals, special interest organizations, and investors, to community leaders and residents, neighborhoods, NGOs, corporations, and transboundary/international interests.

d) Existing uses and development. A related implementation challenge is how spatial planning should take into account existing development as it plans for new development. Decisions about new development cannot be ignorant of what exists already and the externalities that may arise without attention to compatibility. For example, if there are vacation housing around a lake already, it would not be prudent to designate the area for industry which would reduce land values and quality of life of those residents. Connections between existing and new developments will increasingly need attention particularly as both will face the same consequences of current and projected climate change.

\subsection{Science and technology}

a) Data access, integration, and use. Another significant challenge is identifying and keeping up with the best available science, particularly on biodiversity conditions and rate and impacts from climate change. Special skills and capacities are needed to access and filter through the wealth of ecological information and data bases being developed as earth-observing technologies monitor conditions of and changes to geographic spaces important for future development or development control. In addition, there almost always will be important local environmental knowledge about the past, resilience, and change that is valuable input for planning decisions. Inputs must include baseline spatial data on current status and projected spatial and temporal change of land cover, land use, and marine and coastal conditions, and different future scenarios based on best-available projections of physical change and social need.

Geo-spatial and remote-sensing observation systems for generating data and advanced computers for scientific projections of climate change (e.g., for sea level rise, more extreme weather events, storm surge) are improving every year. Much information is readily available at little or no cost to government planners and conservation practitioners worldwide through the internet. But to be fully interpreted and applied for local purposes requires technical skills, expertise, and resources.

Traditionally, data available to planners has consisted of a mere description of features (for example, vegetation maps, species inventories, designated protected areas). There was little or no information analyzing and assessing the value of natural features. Most conservation studies target specific problems, such as identifying ecological corridors or biodiversity hotspots, rather than evaluating the overall biodiversity and ecosystem assets of the region, and the impacts or threats from socio-economic needs and goals. (see, Geneletti, 2008).

Modern conservation planning is beginning to take a more holistic approach, as discussed above. However, until comprehensive conservation plans are available and systematically in- 
tegrated into spatial planning processes, many planning offices especially in developing countries will not have readily-available data for prioritizing natural assets throughout the region as part of sustainable development. Collaboration between planning offices and conservation offices, as well as training and capacity building, will be important for proper use of new geo-spatial databases and understanding how to incorporate the value of biodiversity and ecosystem services to human well-being.

b) Difficulties with habitat creation and ecosystem restoration for climate change. Habitat and ecosystem restoration face major scientific and management challenges to find effective ecological solutions for restoring degraded land and marine space important for such long-term concerns as species habitat, climate change adaptation, or connectivity. In some cases there also may be inadequate or uncertain authority as to who is to undertake restoration measures.

With climate change, these challenges become more complex, particularly in the ecological realm. A 2009 CBD technical report on adaptation strategies for biodiversity identified three specific science and management issues that need attention for addressing the added stress of climate change. These issues are:

i. Understanding the role of extreme events and anticipating potential changes in disturbance regimes that influence successional processes; this will be key to restoring degraded ecosystems;

ii. Focussing on restoration of ecosystem functions and ecosystem resilience rather than species composition - as the climate changes, many species will become increasingly unsuited to conditions within their present day geographic range, making it difficult to re-create the original species composition. Restoring function and adding redundancy will be important in order to support resilience;

iii. For genetic purposes, looking beyond existing species to introducing a mix of new species and individuals containing genetic variations to increase the probability of restoration success and spread risk; this requires careful consideration in order to avoid negative impacts on native biodiversity and also should be consistent with relevant negotiations on access and benefit sharing. (CBD Technical Report 41, pp. 12)

In the context of climate change and biodiversity, these are challenges that need clear policy and law guidance and ongoing collaboration between conservation scientists, planning authorities and affected sectors and communities.

\subsection{Key messages}

Several challenges exist as countries transition to more modern spatial planning. These will be specific and play out in unique ways in different countries depending on their legal systems, social and political goals, environmental priorities, and overall capacities and skills. Specific challenges arise to harmonize and reconcile the many laws and policies related to or impacting biodiversity and climate change. There may be challenges to achieve legal status for plans, or problems with implementation when conflicting proposals get political approval. Working with a longer planning horizon adds risk and uncertainty for the outer years, particularly with climate change. Implementation challenges arise when with data access or use, conflicts among different interests, resource constraints, and finding the right ecological solutions on the ground. 


\section{Policy and law tools - many options}

Three introductory points are important to start this chapter. First, it must be understood that spatial planning is only one tool, though a critical one, for helping countries advance biodiversity goals under the CBD Strategic Plan and require spatial protections to enhance ecosystem resilience and biodiversity adaptation to climate change. It will likely involve several professional disciplines dealing with various aspects of spatial planning including land use, urban planning and urban renewal, marine and coastal planning, regional, transportation, economic, conservation, and community planning. For effectiveness, political will, resources, institutional cooperation, technical expertise, community support and stakeholder participation are all among the essential supporting elements.

Second, it must be acknowledge that even in the more industrialized countries of the OECD, there are substantial differences between countries. Each country making efforts to modernize spatial planning systems biodiversity and climate change will need to find the right combination of process and plan that will work for them. In some countries the national government enforces policies to regulate planning at lower levels. In others, it is the regional authority which regulates spatial planning. In some others, land/marine use powers are decentralized and local authorities have complete control over local land/marine use decisions. The point is that countries must create spatial planning approaches that make the best use of their system of society and government, providing a statutory basis to give some certainty and consistence for future development investments and to protect valuable biodiversity and ecosystems to achieve sustainable development goals.

Third, in spite of the challenges involved, the growing body of planning literature reflects cautious optimism about the potential role for integrated spatial planning to provide the much-needed framework for governments to address sustainability and the needs of future generations, including for biodiversity and climate change. There is no question that building a new approach to public sector planning that is comprehensive, multi-scale, integrated, participatory and long-term will involve a gradual, step-by-step process, with both difficulties and successes. Institutional and social learning will be important. Also necessary will be continuing efforts to use best available scientific evidence to understand current conditions and project future needs, empower diverse governance approaches, resolvie conflicts amicably, use future socio-economic scenarios as part of climate change scenarios, and stay committed to sustainable development in the midst of ongoing global and local change.

In that context, this chapter highlights a diverse array of policy and law tools and approaches that in many legal systems may already be available in some form or could be developed to support implementation of modern planning for both build and natural environments. These offerings are drawn from the extensive technical literature on spatial planning (see references at the end), and the draft global synthesis paper from the 2016 ELC study which offered several generic ideas and messages that remain relevant today. In addition, much of the text on specific policy and law tools was drawn from the two recent IUCN publications that complement this book: IUCN Guidelines for Protected Areas Legislation (Lausche, 2011) and Law and Connectivity Conservation - A Concept Paper (Lausche et al., 2013). The reader is invited to refer to those publications for additional information. 
The chapter is divided into four main parts:

1) inventory in the form of a table of conservation and non-conservation legal instruments, many of which already exist in most countries, to support preparation and implementation of integrated spatial planning, directly or indirectly;

2) core principles important to incorporate in spatial planning laws and related policies;

3) generic cross-cutting provisions for spatial planning law and policy to guide effective plan preparation and implementation; and

4) highlights of specific law and policy tools that can be used for direct regulation of future development according to the spatial plan (carrying over conventional tools), and also incentives through economic and market means (new and emerging tools) to change existing practices in ways that are sensitive to nature conservation, biodiversity and climate change.

\subsection{Inventory of diverse instruments}

There is a vast and diverse array of legal tools and supporting administrative instruments that can be used to directly or indirectly support modern integrated spatial planning. Most countries' legal and administrative systems will include many of these tools and instruments. They generally work in some combination to reinforce the spatial planning and related goals for harmony across the legal system. As a general rule, laws and policies need to be harmonized across sectors and government levels for consistency in application and to avoid conflicts.

Table 6.1 below lists key law and policy instruments in what one might call a toolkit of possibilities to support integrated spatial planning. Beyond identifying the instrument, there is a brief elaboration to help the reader understand the purpose and potential scope. A variety of law and policy tools is included in this one table. The consolidation helps to convey the bigger picture, as well as the diversity, of policy, law, and planning instruments available and, to some extent, their interconnectedness and value for use in combination. Most instruments in some form exist in virtually every country, including in response to international law commitments.

Table 6.1 begins with conventional conservation public sector tools everyone knows, for example, conservation plans and protected areas laws. It then moves to conventional land use planning and development-control instruments, many of which are regulatory. These provide a good legal foundation for modernizing planning systems to be more integrated and spatial for $21^{\text {st }}$ century needs. Economic and fiscal laws come next in this toolkit. These instruments are more non-regulatory and dependent on incentives and voluntary actions. That approach has the potential, which is increasingly being proven, to influence not only future actions but also active and adaptive management of existing land use and marine resource practices by landowners or rightsholders. Finally, market mechanisms are briefly noted to give a sense of the innovative new approaches being tried and expected by some to expand for trading credits and deriving monetary benefits from conservation actions and climate change mitigation.

Taken together, these many instruments comprise a diverse basket of tools for establishing, promoting and reinforcing modern integrated spatial planning to include biodiversity conservation and climate change. They will apply and be useful in unique ways (individually or in combination) for each country, depending on the specific goals and capacities of the country and it's political, legal, economic and social priorities, and the challenges it faces to embrace these new planning needs and essential roles. 
Table 6.1 Law and policy tools to support spatial planning, biodiversity and climate change

\begin{tabular}{|c|c|c|}
\hline $\begin{array}{c}\text { National/ } \\
\text { subnational law/ } \\
\text { policy category }\end{array}$ & Subject focus & Elaboration \\
\hline \multirow[t]{6}{*}{$\begin{array}{l}\text { Conservation and } \\
\text { sustainable use }\end{array}$} & Conservation policy & $\begin{array}{l}\text { National policies relevant for biodiversity and nature conser- } \\
\text { vation should include explicit reference to the commitment } \\
\text { and strategy to integrate those plans and policies into spatial } \\
\text { planning processes and plans, and incorporate also connec- } \\
\text { tivity and climate change adaptation needs for biodiversity } \\
\text { and ecosystem resilience in furtherance of the CBD Strategic } \\
\text { Plan and achieving the UN Sustainable Development Goals. }\end{array}$ \\
\hline & $\begin{array}{l}\text { Conservation plans } \\
\text { and strategies }\end{array}$ & $\begin{array}{l}\text { Biodiversity conservation can be served by national strate- } \\
\text { gies and plans that commit to general or specific goals for } \\
\text { biodiversity conservation, ecosystem maintenance, protect- } \\
\text { ed areas, and connectivity needs. A key instrument under } \\
\text { the CBD is the National Biodiversity Strategy and Action Plan } \\
\text { (NBSAP). In addition, there may be specific plans for particu- } \\
\text { lar conservation needs - watersheds, river systems, coastal } \\
\text { zones, environmentally sensitive areas, connectivity, buffers } \\
\text { against storm surge, etc. Specific plans for biodiversity and } \\
\text { ecosystem adaptation to climate change may also exist. Such } \\
\text { plans and strategies should be integrated into broader spatial } \\
\text { plans and vice versa. }\end{array}$ \\
\hline & $\begin{array}{l}\text { Protected areas } \\
\text { laws }\end{array}$ & $\begin{array}{l}\text { For protected areas to survive, they need to be planned and } \\
\text { managed as part of their broader land-and seas-capes, which } \\
\text { makes it necessary to take into account the influences over } \\
\text { that designated space from adjacent and distant space, as } \\
\text { well as spatial connectivity needs. Many elements of protect- } \\
\text { ed areas laws need to be explicitly addressed in spatial plans, } \\
\text { including designated areas, objectives, management plans, } \\
\text { governance arrangements, buffer zones and other connectiv- } \\
\text { ity needs, along with monitoring and evaluation. }\end{array}$ \\
\hline & $\begin{array}{l}\text { Biodiversity } \\
\text { conservation laws }\end{array}$ & $\begin{array}{l}\text { Some countries have biodiversity laws that apply across all } \\
\text { landscapes/seascapes; normally these are framework laws } \\
\text { that designate priorities and principles for pursuing biodiver- } \\
\text { sity conservation, and these also need integration in compre- } \\
\text { hensive spatial plans. }\end{array}$ \\
\hline & $\begin{array}{l}\text { Nature protection } \\
\text { laws }\end{array}$ & $\begin{array}{l}\text { Some countries have enacted umbrella conservation laws un- } \\
\text { der the label 'nature conservation' or 'nature protection', with } \\
\text { broad conservation goals, sometimes having been enacted } \\
\text { before the term 'biodiversity' came into favour, protecting } \\
\text { nature generally, specific species or ecosystems. Such laws } \\
\text { provide a framework for nature conservation activities includ- } \\
\text { ing establishing protected areas and connectivity zones, all } \\
\text { of which have spatial elements important to incorporate in } \\
\text { spatial plans. Through such instruments, some countries are } \\
\text { prioritizing conservation efforts in specific ecosystems under } \\
\text { threat. }\end{array}$ \\
\hline & $\begin{array}{l}\text { Wildlife } \\
\text { conservation/ } \\
\text { management laws }\end{array}$ & $\begin{array}{l}\text { These could include general wildlife conservation laws, e.g., } \\
\text { specific species needing some level of special protection, and } \\
\text { hunting laws to control hunting and fully or partially protect } \\
\text { some species.These may guide decisions on species needing } \\
\text { support with special connectivity conservation measures }\end{array}$ \\
\hline
\end{tabular}




\begin{tabular}{|c|c|c|}
\hline $\begin{array}{l}\text { National/ } \\
\text { subnational law/ } \\
\text { policy category }\end{array}$ & Subject focus & Elaboration \\
\hline & & $\begin{array}{l}\text { and when. Legal aspects could include critical habitat desig- } \\
\text { nations, recovery plans, habitat conservation plans on public } \\
\text { or private lands, and recognition for voluntary conservation of } \\
\text { certain listed species, all relevant for spatial planning. }\end{array}$ \\
\hline & $\begin{array}{l}\text { Sustainable use } \\
\text { laws }\end{array}$ & $\begin{array}{l}\text { Sustainable use laws are becoming increasingly common to } \\
\text { maintain diversity and interconnectedness of biological sys- } \\
\text { tems that support productivity of the resource, sustain eco- } \\
\text { system services, support socio-economic needs and recog- } \\
\text { nize diverse governance approaches, all of which are relevant } \\
\text { for spatial planning. Examples include laws on sustainable } \\
\text { forests, soils, fisheries, and agriculture. }\end{array}$ \\
\hline & $\begin{array}{l}\text { Specific ecosystem } \\
\text { or habitat-type laws }\end{array}$ & $\begin{array}{l}\text { A growing number of countries have laws to protect specific } \\
\text { local ecosystems, habitat types and other ecologically impor- } \\
\text { tant areas wherever they occur, e.g., wetlands, watersheds, } \\
\text { river banks, coastal zones, coral reefs, etc. These spatial are- } \\
\text { as are typically some of the most important in servicing critical } \\
\text { connectivity functions for species and ecosystem processes. }\end{array}$ \\
\hline & $\begin{array}{l}\text { Stand-alone } \\
\text { Connectivity laws }\end{array}$ & $\begin{array}{l}\text { Specific law/policy authorizing connectivity conservation are- } \\
\text { as and practices could take different approaches, including: } \\
\text { l) generic connectivity legislation, 2) site-specific connectivity } \\
\text { legislation, or 3) use of other instruments such as agreements } \\
\text { or MOUs. Objectives include protecting spatial needs for spe- } \\
\text { cies and ecosystems, and adaptation to climate change. }\end{array}$ \\
\hline & $\begin{array}{l}\text { Laws protecting } \\
\text { environmental flows }\end{array}$ & $\begin{array}{l}\text { Some countries have policies and laws to protect natural wa- } \\
\text { ter flows, with water laws that focus explicitly on maintaining } \\
\text { basic hydrologic systems and hydrologic connectivity. Some- } \\
\text { times the focus is on taking an 'integrated water management } \\
\text { approach' or policy, and as part of this, spatial planning needs } \\
\text { to protect these ecosystem functions and services. }\end{array}$ \\
\hline Land use planning & Land use plans & $\begin{array}{l}\text { Should be legally binding; guide development decisions about } \\
\text { land and resource use; mostly through regulatory tools such } \\
\text { as zoning, permits, and conditions regarding building design, } \\
\text { and space allocation. In many countries, broader spatial plan- } \\
\text { ning systems are supplementing or replacing convention- } \\
\text { al land use planning. Land use plans in some countries are } \\
\text { non-legally binding but still relevant for policy. }\end{array}$ \\
\hline & $\begin{array}{l}\text { Strategic } \\
\text { environmental } \\
\text { assessments (SEA) }\end{array}$ & $\begin{array}{l}\text { SEA is a valuable tool for identifying environmental consid- } \\
\text { erations that need to be integrated into preparation of plans } \\
\text { and programmes prior to their adoption. The objectives } \\
\text { of SEA are to provide for a high level of protection of the } \\
\text { environment in such plans and programmes and to promote } \\
\text { sustainable development. It is a valuable additional tool for } \\
\text { incorporating biodiversity conservation needs and climate } \\
\text { change considerations into land use and broader spatial } \\
\text { planning. SEA includes systematic assessments of current } \\
\text { and potential future developments, e.g., whether certain } \\
\text { infrastructure projects or large spatial developments may } \\
\text { have a major impact on biodiversity, ecosystem resilience, } \\
\text { connectivity and climate change adaptation needs. }\end{array}$ \\
\hline
\end{tabular}




\begin{tabular}{|c|c|c|}
\hline $\begin{array}{c}\text { National/ } \\
\text { subnational law/ } \\
\text { policy category }\end{array}$ & Subject focus & Elaboration \\
\hline \multirow[t]{5}{*}{$\begin{array}{l}\text { Development } \\
\text { controls }\end{array}$} & Zoning laws & $\begin{array}{l}\text { Zoning is a regulatory tool used especially in urban planning, } \\
\text { suburban planning and some rural planning to facilitate com- } \\
\text { patible development and exclude incompatible development, } \\
\text { and has significance for protecting key biodiversity sites, con- } \\
\text { nectivity areas, and recognizing spatial needs associated with } \\
\text { climate change species adaptation and ecosystem resilience, } \\
\text { in both urban and rural environments. }\end{array}$ \\
\hline & $\begin{array}{l}\text { Environmental } \\
\text { impact Assessment }\end{array}$ & $\begin{array}{l}\text { Development control legislation often requires an environ- } \\
\text { mental impact assessment in advance of approving a specific } \\
\text { development application and an important aspect for assess- } \\
\text { ment is the potential negative environmental impact, singly } \\
\text { and cumulatively, on nature, biodiversity and ecosystem ser- } \\
\text { vices on or off site. }\end{array}$ \\
\hline & $\begin{array}{l}\text { Attaching } \\
\text { conditions to } \\
\text { development } \\
\text { permits }\end{array}$ & $\begin{array}{l}\text { A common approach in development control laws is to author- } \\
\text { ize the use of conditions to approval. Such conditions may re- } \\
\text { quire protective or mitigating measures. Conditions attached } \\
\text { to approvals have a significant role to play in protecting con- } \\
\text { servation values of the site and recognizing spatial needs for } \\
\text { climate change adaptation of species and ecosystems. }\end{array}$ \\
\hline & $\begin{array}{l}\text { Modifying } \\
\text { conditions for } \\
\text { climate change }\end{array}$ & $\begin{array}{l}\text { One development control tool useful for conservation is some- } \\
\text { times called the 'reopener clause'. This clause is useful when } \\
\text { it is difficult to predict the precise environmental or social im- } \\
\text { pacts when an approval is initially sought or when changing } \\
\text { circumstances are anticipated, e.g., climate change or other } \\
\text { unexpected change. This clause may be part of the conditions } \\
\text { of approval and authorizes re-opening the permit to re-evalu- } \\
\text { ate environmental impacts due to uncertainties. }\end{array}$ \\
\hline & $\begin{array}{l}\text { Offsets for } \\
\text { biodiversity } \\
\text { damage, relates } \\
\text { to conservation } \\
\text { banking (see below) }\end{array}$ & $\begin{array}{l}\text { This tool should be used only as last resort, according to envi- } \\
\text { ronmental practitioners. The tool aims to ensure no net loss of } \\
\text { conservation values overall when approving a project (after all } \\
\text { other mitigation or avoidance measures have been taken, and } \\
\text { ideally also improvements) by attaching extra conditions to the } \\
\text { approval requiring the developer to offset loss by active con- } \\
\text { servation management/investment of another site to achieve } \\
\text { comparable conservation value, some jurisdictions also allow } \\
\text { conservation credits and conservation banking (biobanking) } \\
\text { schemes. Scientifically controversial because difficult to know } \\
\text { real net biodiversity loss of particular sites and to achieve full } \\
\text { replacement at a completely different site. }\end{array}$ \\
\hline $\begin{array}{l}\text { Voluntary } \\
\text { conservation } \\
\text { agreements }\end{array}$ & $\begin{array}{l}\text { By specific } \\
\text { legislation, or } \\
\text { private contract }\end{array}$ & $\begin{array}{l}\text { Voluntary conservation agreements are a principal instrument } \\
\text { available to governments, individuals, and organizations to } \\
\text { pursue a voluntary approach to land or resource management } \\
\text { to achieve conservation objectives, including for connectivity } \\
\text { and ecosystem resilience. They may be used to promote vol- } \\
\text { untary actions to change existing uses to be more compatible } \\
\text { with spatial plan goals related to conservation of biodiversity } \\
\text { and maintenance or restoration of ecosystem services. This } \\
\text { tool has significant potential for changing behaviour in favour } \\
\text { of conservation, especially when there are incentives (as not- } \\
\text { ed next) and legal certainty. }\end{array}$ \\
\hline
\end{tabular}




\begin{tabular}{|c|c|c|}
\hline $\begin{array}{c}\text { National/ } \\
\text { subnational law/ } \\
\text { policy category }\end{array}$ & Subject focus & Elaboration \\
\hline \multirow[t]{5}{*}{$\begin{array}{l}\text { Economic } \\
\text { instruments/ } \\
\text { incentives }\end{array}$} & $\begin{array}{l}\text { Payments for } \\
\text { changing existing } \\
\text { management }\end{array}$ & $\begin{array}{l}\text { Positive economic incentives can be used to encourage pri- } \\
\text { vate landholders and resource rights holders to change ex- } \\
\text { isting management practices that adversely impact on bio- } \\
\text { diversity and ecosystems. Incentive payments, for example, } \\
\text { could be used to take land out of agriculture production for } \\
\text { conservation purposes or to prevent planting fast-growing ex- } \\
\text { otic trees in semi-natural forests. Such payments help com- } \\
\text { pensate for lost near-term production or reduced land value, } \\
\text { and help promote sustainable land and resource use. }\end{array}$ \\
\hline & $\begin{array}{l}\text { Payments for new } \\
\text { management }\end{array}$ & $\begin{array}{l}\text { Positive economic incentives also could be used to promote } \\
\text { active management for conservation. For example, a program } \\
\text { of incentives could support regeneration of degraded ecosys- } \\
\text { tems (e.g, removing invasive plants) or active restoration or } \\
\text { even re-creation of natural habitats for wildlife, or natural flows } \\
\text { of river systems. }\end{array}$ \\
\hline & $\begin{array}{l}\text { Subsidies to } \\
\text { farmers, foresters, } \\
\text { fishers, or other } \\
\text { resource users to } \\
\text { comply with certain } \\
\text { conservation and } \\
\text { connectivity-sup- } \\
\text { portive practices for } \\
\text { that resource }\end{array}$ & $\begin{array}{l}\text { An example here is the policy of Member States of the Euro- } \\
\text { pean Union to support agro-environment payments to farmers } \\
\text { for biodiversity conservation among other things, including to } \\
\text { support conservation practices for connectivity in high-value } \\
\text { biodiversity areas such as wetlands and species-rich grass- } \\
\text { lands. Payments might be made through individual contracts, } \\
\text { unilateral subsidies or public procurement. }\end{array}$ \\
\hline & $\begin{array}{l}\text { Payments for } \\
\text { ecosystem services } \\
\text { (PES) }\end{array}$ & $\begin{array}{l}\text { PES is a particular type of economic instrument receiving } \\
\text { increased attention from both public authorities and private } \\
\text { landholders or rights-holders in relation to their management } \\
\text { of land/sea and freshwater resources. To be effective, PES } \\
\text { schemes need to be grounded in law. Normally, agreements } \\
\text { are concluded between land/rights holders with government } \\
\text { or private corporations for commitments to maintain or restore } \\
\text { certain land uses compatible with the production of ecosys- } \\
\text { tem services (e.g., hydrologic services, mitigation of green- } \\
\text { house gas emissions, biodiversity conservation, provision of } \\
\text { scenic beauty for ecotourism, watershed services, etc.). }\end{array}$ \\
\hline & $\begin{array}{l}\text { Direct funding } \\
\text { of conservation, } \\
\text { connectivity, and } \\
\text { climate change } \\
\text { adaptation projects }\end{array}$ & $\begin{array}{l}\text { Programs which provide direct funding for specific conserva- } \\
\text { tion or restoration projects, under strict conditions, may be a } \\
\text { strong support tool for achieving certain conservation actions, } \\
\text { including for climate change adaptation. One example of in- } \\
\text { novation in this area is the LIFE programme of the European } \\
\text { Union which, among other things, aimed to co-finance 'green } \\
\text { infrastructure' defined as "a network of green areas and fea- } \\
\text { tures in rural and urban landscapes which can enhance the } \\
\text { resilience of species and ecosystems in adapting to climate } \\
\text { change while securing multiple benefits for biodiversity and } \\
\text { humans and ensuring the provision of ecosystem goods and } \\
\text { services". }\end{array}$ \\
\hline Market creation & \multicolumn{2}{|c|}{$\begin{array}{l}\text { [where governments create new private sector markets that advance nature con- } \\
\text { servation and resilience for climate change, including for connectivity, e.g., forest } \\
\text { credits or carbon sequestration rights] }\end{array}$} \\
\hline
\end{tabular}




\begin{tabular}{|c|c|c|}
\hline $\begin{array}{c}\text { National/ } \\
\text { subnational law/ }\end{array}$ & Subject focus & Elaboration \\
\hline & $\begin{array}{l}\text { Conservation } \\
\text { banking }\end{array}$ & $\begin{array}{l}\text { Also known as habitat banking or biobanking. Such legislation } \\
\text { provides that land/rights holders can create biodiversity cred- } \\
\text { its for active conservation management (which could include } \\
\text { for connectivity and adaptation purposes) on their lands/re- } \\
\text { sources to enhance biodiversity values and ecosystem resil- } \\
\text { ience; credits can be sold. Generally linked to offsets from } \\
\text { biodiversity damage (see above); developers pay for conser- } \\
\text { vation on other private lands, rather than using government } \\
\text { incentives. }\end{array}$ \\
\hline & $\begin{array}{l}\text { Tradable develop- } \\
\text { ment rights (TDRs) }\end{array}$ & $\begin{array}{l}\text { A voluntary tool creating a market comprised of development } \\
\text { credits, not conservation credits. As a zoning technique, this } \\
\text { tool can be used to permanently protect farmland, coastal } \\
\text { areas, and other important natural and cultural resources by } \\
\text { redirecting development that would otherwise occur on these } \\
\text { sites to areas planned to accommodate growth and develop- } \\
\text { ment. The land from which the development rights have been } \\
\text { severed is permanently protected through a conservation } \\
\text { easement or other appropriate form of restrictive covenant, } \\
\text { and the development value of the land where the transferred } \\
\text { development rights are applied is enhanced by allowing for } \\
\text { new or special uses, greater density or intensity, or other reg- } \\
\text { ulatory flexibility that zoning without the TDR option would not } \\
\text { permit. }\end{array}$ \\
\hline & $\begin{array}{l}\text { Linking } \\
\text { conservation to } \\
\text { emissions trading }\end{array}$ & $\begin{array}{l}\text { In some countries, an instrument in climate change policy is an } \\
\text { Emissions Trading Scheme (ETS). There is discussion about } \\
\text { to connecting forests by allowing greenhouse gas emitters to } \\
\text { purchase forest credits as an alternative to permits, and there- } \\
\text { by stimulate forestry conservation and connectivity measures. } \\
\text { This idea is connected to the UN Framework Convention on } \\
\text { Climate Change, REDD+ initiative. }\end{array}$ \\
\hline $\begin{array}{l}\text { Special area-based } \\
\text { management } \\
\text { tools for marine } \\
\text { conservation }\end{array}$ & MPA networks & $\begin{array}{l}\text { MPAs and MPA networks provide the primary area-based } \\
\text { management tool for directly conserving marine biodiversity } \\
\text { and ecosystems and building resilience for climate change. } \\
\text { Connectivity is inherent in the MPA network concept as well. } \\
\text { The MPA network approach needs to be recognized in MPA } \\
\text { legislation as a valuable area-based management tool with } \\
\text { these core objectives among its purposes. }\end{array}$ \\
\hline & $\begin{array}{l}\text { Ecosystem-based } \\
\text { marine } \\
\text { management }\end{array}$ & $\begin{array}{l}\text { Scientists are increasingly recognizing the need for an eco- } \\
\text { system-based approach for use, protection, and management } \\
\text { of marine and coastal resources and this concept is increas- } \\
\text { ingly being incorporated in legislation on conservation and } \\
\text { sustainable use. Ecosystem-based management is a spatial } \\
\text { or area-based management approach that necessarily re- } \\
\text { quires attention to connectivity conservation as well. }\end{array}$ \\
\hline & $\begin{array}{l}\text { Marine spatial } \\
\text { planning (MSP) }\end{array}$ & $\begin{array}{l}\text { MPS is a public process to analyze, plan, and identify different } \\
\text { human uses of the marine area in order to achieve certain eco- } \\
\text { logical, economic and social objectives. As a relatively new } \\
\text { tool for marine management, several ecological principles are } \\
\text { recoginzed, including maintaining native species diversity, } \\
\text { sustainable use of marine resources, and sustainable provi- } \\
\text { sion of ecosystem services. MSP initiatives are underway in } \\
\text { many countries as a planning tool to help make informed de- } \\
\text { cisions about marine conservation and sustainable use. }\end{array}$ \\
\hline
\end{tabular}




\begin{tabular}{|c|c|c|}
\hline $\begin{array}{c}\text { National/ } \\
\text { subnational law/ }\end{array}$ & Subject focus & Elaboration \\
\hline & & $\begin{array}{l}\text { This tool may lead to regulatory measures or remain a plan- } \\
\text { ning tool advising and giving guidance to government agen- } \\
\text { cies authorizing use of specific marine space. }\end{array}$ \\
\hline & Ocean zoning & $\begin{array}{l}\text { Ocean zoning is another management strategy specific to the } \\
\text { marine environment. It is related to marine spatial planning be- } \\
\text { cause it commonly requires a plan on which to do zoning and } \\
\text { regulation. The plan is given effect through regulatory tools } \\
\text { for some or all areas of the marine space being considered. } \\
\text { Zoning regulations relate not only to existing uses, but also } \\
\text { to anticipated future uses, ecologically critical and sensitive } \\
\text { areas, and scenarios including climate change. }\end{array}$ \\
\hline & $\begin{array}{l}\text { Integrated coastal } \\
\text { and ocean } \\
\text { management }\end{array}$ & $\begin{array}{l}\text { The concept of integrated coastal zone management (or } \\
\text { integrated coastal and ocean management) is another ar- } \\
\text { ea-based management tool for on-the-ground integration and } \\
\text { coordination of the many policies, sectors, laws, interests, and } \\
\text { administrative levels involved in the coastal zone (a discrete } \\
\text { area of interaction between the land and the sea). In many } \\
\text { jurisdictions, the concept has been incorporated in national } \\
\text { legislation as a way to manage coastal growth and the mul- } \\
\text { tiple functions of the coastal zone. This concept to be effec- } \\
\text { tive should incorporate connectivity factors from upstream to } \\
\text { near-shore waters, and be reflected in the corresponding part } \\
\text { of spatial plans addressing future coastal development or de- } \\
\text { velopment negatively impacting the coastal zone. }\end{array}$ \\
\hline
\end{tabular}

(Source: condensed from Lausche et al., 2013, pp. 77-170)

\subsection{Principles for policy and law}

There is extensive material in the literature on principles to guide policy makers and practitioners as they work to modernize public sector planning for a more integrated spatial approach. These include principles related to process, many of which are noted in chapters above. They also include principles specific to planning for biodiversity conservation and for adaptation to climate change. Then there also are principles related specifically to urban planning and agricultural planning to protect biodiversity and ecosystem resilience. These aspects are briefly highlighted here for their relevance, in particular, for policy and law.

\subsubsection{Generic principles}

Generic elements in modern spatial planning processes and plans appear repeatedly in recent literature (see, e.g., Metternicht, 2017, and Wilson \& Piper, 2010). They are worth recognizing, where feasible, in planning policy, supporting legal frameworks, and operational guidance. Apart from the first two items below, which are discussed in some depth in chapter three above, other elements noted include some elaboration their value in being recognized in corresponding law and policy frameworks.

a) Long-term planning horizon and an ecosystem approach. As elaborated in chapter three above, there is broad consensus in the literature that these two elements are among the most fundamental features differentiating conventional planning approaches from modern integrat- 
ed spatial planning. The longer planning horizon is essential to adequately plan for current and projected impacts from climate change on both build and natural environments over the medium and long term. And as required by the Convention on Biological Diversity and its extensive supporting guidance, an ecosystem-based approach is needed at all levels and sectors when assessing threats and planning future actions to restore and sustain biodiversity. This includes planning elements to protect Key Biodiversity Areas.

b) Legally grounded planning processes and plans: Spatial planning processes and plans need to be grounded in law. Legal frameworks should be explicit about the main requirements, authority, and compliance elements for preparation, design, approval, implementation and evaluation. This includes being explicit about the requirement to incorporate biodiversity conservation and climate change in plan deliberations and resulting plan content using the best available science. Statutory status should apply not only to the preparation process of the plan but also, explicitly, to implementation of priority components with penalties for non-compliance.

Other government plans, both sectoral and topic-specific, should be required to collaborate with and harmonize with the more comprehensive and integrated spatial plan, along with any biodiversity protections and measures needed to build ecosystem resilience for climate change. There should be a provision to prioritize ecosystem and ecosystem services needing special protections according to clear rules and indicators, with trigger clauses which can re-open and re-evaluate spatial decisions. There also should be recognition of diverse governance actors in all planning stages, and use of good governance principles, including social equity and environmental justice, in decision-making.

c) Policy integration and coordination: Spatial planning needs to be understood and negotiated within the wider context in which it will function. This means an interdisciplinary understanding and awareness. To achieve this, coordination of sectoral policies and laws represents one of the main strategic objectives of contemporary spatial planning. Coordination of public sector activity across different departments is a central feature and one of the main "traditions" of spatial planning in Europe that is beginning to spread to other countries (see, e.g., Stead and Meijers, 2009; Stead has written widely on this in the EU context). Policy integration and coordination are needed across sectors at all levels (horizontal coordination), across all levels of government (vertical coordination). The aim should be to incorporate the bottom-up aspects with the top-down aspects.

While these concepts are gaining acceptance in principle, studies have found that sector policy integration is not a high priority for key actors in many governments (Stead and Meijers, 2009). At the same time, it is common for modern spatial planning policy documents to reference the need for sectoral policy integration. The challenge is to find practical ways to achieve this.

A useful tactic is to promote the benefits of integrated sector policies and, as appropriate, incorporate them within policy and law instruments as goals and objectives for policy integration. Such benefits include to -

- Promote synergies between sectors (win-win solutions);

- Reduce duplication in the policy-making process;

- Promote consistency of policies between sectors and levels of decision making; 
- Improve achievement of cross-cutting goals (e.g., climate change adaptation and mitigation; biodiversity conservation, overall sustainable development);

- Advance understanding of the effects of spatial planning policies on other sectors.

d) Connecting biodiversity and climate change mitigation and adaptation: CBD technical report 41, "Connecting Biodiversity and Climate Change Mitigation and Adaptation", highlights several principles for policy and planning frameworks for both land and marine environments. The report emphasizes that the most fundamental principle for integrated spatial planning is to continue to promote the conservation of intact and functioning ecosystems wherever possible. Several supporting principles are provided, including:

i. Reducing other stresses on species and ecosystems, including from habitat loss and fragmentation, invasive alien species, pollution, and overharvesting. Reducing these threats is necessary to maximize the resilience of species and ecosystems to climate change.

ii. Increasing protected area systems and improving the connectivity of protected areas and natural landscapes/seascapes to provide opportunities for species to adapt to climate change by migration, and to increase the probability of maintaining viable populations of species.

iii. Identifying locations within landscapes/seascapes where species have maintained populations in the face of past climate change (past climate refugia) and focus conservation efforts in these locations.

iv. Identifying existing locations that contain diverse environmental conditions (including latitudinal and elevational gradients, levels of moisture, soil types, etc.) in which to focus conservation efforts, as these areas are likely to provide the widest range of habitats in the future.

v. Prioritizing areas of high endemism, as many of these have been relatively climatically stable for millions of years and have species with a high degree of specialization. As the options for relocation may be minimal, intensive efforts to maintain these areas in the face of climate change, and preserve their genetic diversity, may be crucial.

vi. Actively managing for climate-related disturbance events, such as floods or droughts that may alter in both frequency and intensity in the future.

e) Cooperative governance and stakeholder participation: It is important to recognize in appropriate policy and law instruments the need for integrated, cooperative governance among all actors and broad participation with spatial plan development and implementation. Subject to local legal practice, and respecting the rule of law and legal pluralism, it may also be worthwhile to reiterate the application in all decision-making of good governance principles including transparency, social equity, benefit sharing, and justice.

Ensuring public engagement and participation at the local level is particularly needed because the institutions closest to the resources at stake are where implementation and management responsibility ultimately falls (sometimes this is called the subsidiary principle). Communities and their neighborhoods can assess local conditions and plan the future in much more detail than is typically done in the central or national-level plan. This is the level where specific sectoral and spatial conflicts may arise. It is also where other 'soft' planning initiatives have been 
taken (see discussion below). Local knowledge about biodiversity resources and ecosystem services as well as sustainable use practices of local land and resources can provide valuable information for planning purposes generally as well as specifically for biodiversity conservation needs and climate change mitigation and adaptation measures.

Even though spatial plan implementation is primarily a local task and concerns local issues, it still has consequences for issues of national and global importance - long-term stability of ecosystems, social justice, food and energy security, long-term economic growth, housing costs, and the mitigation of and adaptation to climate change. This inevitably brings in the global scope to planning, a complicated element for local planning.

f) Address risk and uncertainty. Long-range future planning presents special problems of uncertainty of knowledge about the extent, rate and type of changes that may happen in the medium or long-term future. This creates uncertainties for calculating likely impacts and the needed planning interventions to secure, among other things, biodiversity conservation goals and effective climate change responses. A key guiding principle for decision-making, especially when dealing with uncertainties of climate change, is the precautionary principle, discussed at length in chapter three above. That principle should be recognized in appropriate law and policy guidance for spatial planning processes and plans.

A specific risk assessment tool to which the precautionary approach should apply is the anticipatory assessment. Anticipatory assessment of risk that certain outcomes will not occur as planned is an essential input to effective spatial planning over the long term. Associated with this, it is important to take a climate risk-based approach which considers gradual change over the long term, but also extremes in the short-term. These are elements to recognize and authorize in policy and law as part of the toolkit of tools for effective spatial planning.

To cope with uncertainties, experts also advise that scenarios and 'futures-thinking' planning are useful tools for anticipating different outcomes and incorporating a whole-system perspective. Uncertainties about future climate change and where the impacts will be the most severe is a particular problem which requires calculating risks of different options or the near, medium, and long-term (see, Wilson and Piper, 2010). Scenarios thinking can involve many sectoral inputs and participants - government, non-government, technical, local - and can help inform decision makers about the different drivers, influences, and potential tipping points affecting sustainability that have low controllability. This includes biodiversity and climate change. The ability of decision makers collectively to identify, debate, and evaluate alternative futures and policy options under conditions of risk and uncertainty improves buy-in by stakeholders and promotes credibility and political support (Kubiszewski et al., 2017).

g) Build in flexibility: The principle of flexibility, within limits, is another important principle to reflect in spatial planning law and policy. Spatial plans must be clear which spatial areas require special management and conservation measures for biodiversity and climate change and other important social and economic goals. At the same time, provisions on monitoring for the plans should allow for some flexibility to adjust to new circumstances and react in a timely and creative way to new and anticipated challenges. Flexible implementation is also important for policy integration.

An important caveat is that more flexibility should not be embraced everywhere. Formal protected areas and community conserved areas, environmentally sensitive areas (e.g., coral reefs, and watersheds), historic or culturally-important sites, connectivity areas, adaptation 
areas, or ecosystems under threat or in need of restoration need more stringent rules than transitional spaces such as brownfield sites (where there was prior development) or greenfield sites (agricultural or other land without prior infrastructure). Flexible planning is facilitated by indicating in the plans those areas needing a sustained status according to their protection or other needs, and planning procedures should follow accordingly. For flexible planning, a high degree of capacity is needed at the local level since a broader range of considerations must be taken into account for any adjustments.

h) Recognize 'Soft' planning tools. In some countries, formal planning systems have been slow to respond and modernize for the new growth pressures and needs. As a consequence informal planning initiatives have started to emerge especially since the 1990s to reinforce formal planning and as needed to advance local planning needs and goals. New forms of space-related planning are being created as communities, neighborhoods, and particular sectors take initiatives with planning implications to address particular concerns or interests, e.g., preserving local and traditional land/marine uses, protecting important cultural and natural sites, limiting or forbidding certain development, attracting special kinds of investment, or preparing for emergencies and disaster recovery.

Traditionally, these 'soft' planning tools had been seen as unrelated to plan-making. Today, they are an additional layer of informal planning that may have long-term and potentially irreversible impacts on the land/marine space. To avoid conflict or to avoid foreclosing future options, these 'soft' planning instruments and should be coordinated with the overall spatial planning system and its goals, objectives, and constraints.

Use of 'soft' planning is proliferating. For instance, within the energy sector, there may be integrated strategies for sustainable energy use. These strategic plans may be statutory as required by law or non-statutory and adopted by communities as well as private/public partnerships as 'good practice'. The result of such initiatives is a blend of formal statutory space planning (e.g., national spatial plans, municipal development plans, regional development plans) and informal planning of spaces (e.g., local municipality sustainability plans, utilities or transportation strategic plans, local climate change adaptation strategies, biodiversity strategies, 'smart growth' and 'sustainable communities' strategies, hybrid plans between core cities and their metropolitan sub-regions in the form of city/peri-urban region plans).

At the local level other informal initiatives also are being taken to protect spaces and ecosystem services as communities gain knowledge about the inter-connections between economic and environmental sustainability. Environmental stewardship activities initiated on private, community, and public lands aim to advance specific needs, for example, watershed management schemes to protect the local water supply, pollution clean-up, or ridding an area of invasive species. Informal groups may form to monitor and collect environmental data on specific spaces for health and safety reasons, e.g., litter control, local toxic spills or run-off, local disasters. Neighborhood or community groups may volunteer for clean up the garbage and waste in certain urban, village, or rural areas and restore fields or habitat with new farm practices or green infrastructure (see, e.g., Allmendinger \& Haughton 2010).

In the marine environment, especially with economically-important uses, informal arrangements for management of specific spaces or zones also are being negotiated between different user groups and coastal communities to reduce conflict and collaborate on sustainable management. Some coastal communities and indigenous or traditional groups with custom- 
ary or statutory resource use rights may create operational plans and monitoring provisions with neighboring users. In some parts of the world, these practices are informal and have been functioning for generations. As attention is more and more drawn to issues of marine degradation from overuse or abuse, marine spatial planning is also gaining attention to control or manage specific uses (see Chapter 6.5 for an overview of special issues for marine spatial planning).

\subsubsection{Urban principles}

a) Urban components of plans should protect biodiversity and ecosystems. Today, roughly $55 \%$ of the world's population lives in urban areas, a proportion that is expected to increase to $68 \%$ by 2050 . Projections show that urbanization, the gradual shift in residence of the human population from rural to urban areas, combined with the overall growth of the world's population could add another 2.5 billion people to urban areas by 2050 , with close to $90 \%$ of this increase taking place in Asia and Africa, according to a 2018 United Nations report (UN DESA, 2018).

Urbanization is viewed as endangering critical habitats of global value and some experts have concluded it "is more ubiquitous than any other human activity affecting biodiversity, climate, water, and nutrient cycles at multiple scales" (Gret-Regamey et al., 2017). The impacts of growing urban areas on the environment are complex and cover both social and ecological aspects at different scales, ranging from changes in social structures to the loss of ecosystem functions and the provision of ecosystem services.

b) Promote environmentally sensitive urban growth. The important point for law and policy is to recognize that spatial planning should include urban and peri-urban planning as part of the process and resulting plan, including for environmental purposes. Spatial planning has only recently started focusing on the design of alternative urban patterns that are more environmentally sensitive (including, 'smart growth', 'low impact development', 'sustainable cities'). These techniques, increasingly grounded in law, will be important to disseminate across countries, especially in the developing world, as urbanization significantly outpaces rural settlements.

\subsubsection{Agricultural principles}

a) Agricultural components of plans should protect biodiversity and ecosystems. The current ecological footprint of agriculture has dramatically increased in recent decades, according to the Millennium Ecosystem Assessment (MEA, 2005). Impacts on terrestrial land and freshwater use have been profound and mostly negative for biodiversity and ecosystems. Most water use worldwide is for agriculture (70 per cent), millions of hectares of forests and natural vegetation have been cleared for agriculture, half of the world's wetlands have already been converted, overuse and mismanagement of pesticides have polluted water and land, pesticide run-off and livestock wastes have become major contaminants of freshwater, estuaries and tidal streams. It is projected that, under current production practices, growing demand for agricultural products to feed a population approaching 9 billion by mid-century will require land conversion of several million more hectares of natural habitat in more and more fragile and ecologically sensitive areas. 
b) Promote compatible practices for sustainable agriculture, biodiversity conservation, and climate change. A major feature of much high-production agriculture has been to keep areas for agriculture segregated from areas for biodiversity conservation and ecosystem protection. This is not a sustainable approach over the long-term. In addition, agriculture is a highly sensitive sector to climate change. Spatial planning has a key role to play helping promote agricultural practices that are less damaging to natural systems, that respect the relationship between conservation, sustainable agriculture and sustainable livelihoods, and have resilience to adapt to climate change. As elaborated in an article about sustainable agriculture and biodiversity conservation, conserving biodiversity and ecosystem services is key to sustainable agriculture (Scherr \& McNeely, 2007).

c) An eco-agriculture landscape perspective. One approach to spatial planning of agricultural areas for biodiversity and climate change is to plan future use based on a broader landscape perspective, rather than only a site-by-site perspective. Practitioners consider this scope can better respond to biodiversity and ecosystem service needs, ecosystem management, and agricultural diversification to adapt to climate change. This has been characterized as an 'eco-agriculture landscape' approach with the objective to explicitly recognize economic and ecological relationships and mutual inter-dependencies among agriculture, biodiversity, and ecosystem services (Id.). Ecosystem services and these linkages are illustrated in Figure 6.1 below.

According to experts, such an approach would need to pursue a resource management strategy that sustainably increased farm outputs while reducing costs in ways that would enhance habitat quality and ecosystem services. This approach reinforces what some are calling the 'circular economy', an emerging theme which focuses on maximizing the reuse of resources and minimizing their depreciation, in this case requiring concise management of the resources, land and soil.

d) Harmonize production goals with conservation. As highlighted in the Millennium Ecosystem Assessment, to facilitate an eco-agricultural strategy it would be important to promote diffusion of agricultural science and technology that could sustain the necessary increase in food supply without harmful tradeoffs involving excessive use of water, nutrients, or pesticides (MEA, 2005, p. 35). Toward that end, Scheer and McNeeley (in their article noted above) offer some specific eco-agricultural landscape practices for sustainable agriculture and biodiversity conservation that could be incorporated in agricultural components of spatial plans (ld., p. 481), as well as supported by appropriate law and policy instruments. These include to:

i. Minimize agricultural wastes and pollution,

ii. Manage resources in ways that conserve water, soils, and wild flora and fauna,

iii. Use crop, grass and tree combinations to mimic the ecological structure and function of natural habitats,

iv. Minimize or reverse conversion of natural areas,

v. Protect and expand larger patches of high-quality natural habitat, and

vi. Develop effective ecological networks and corridors. 


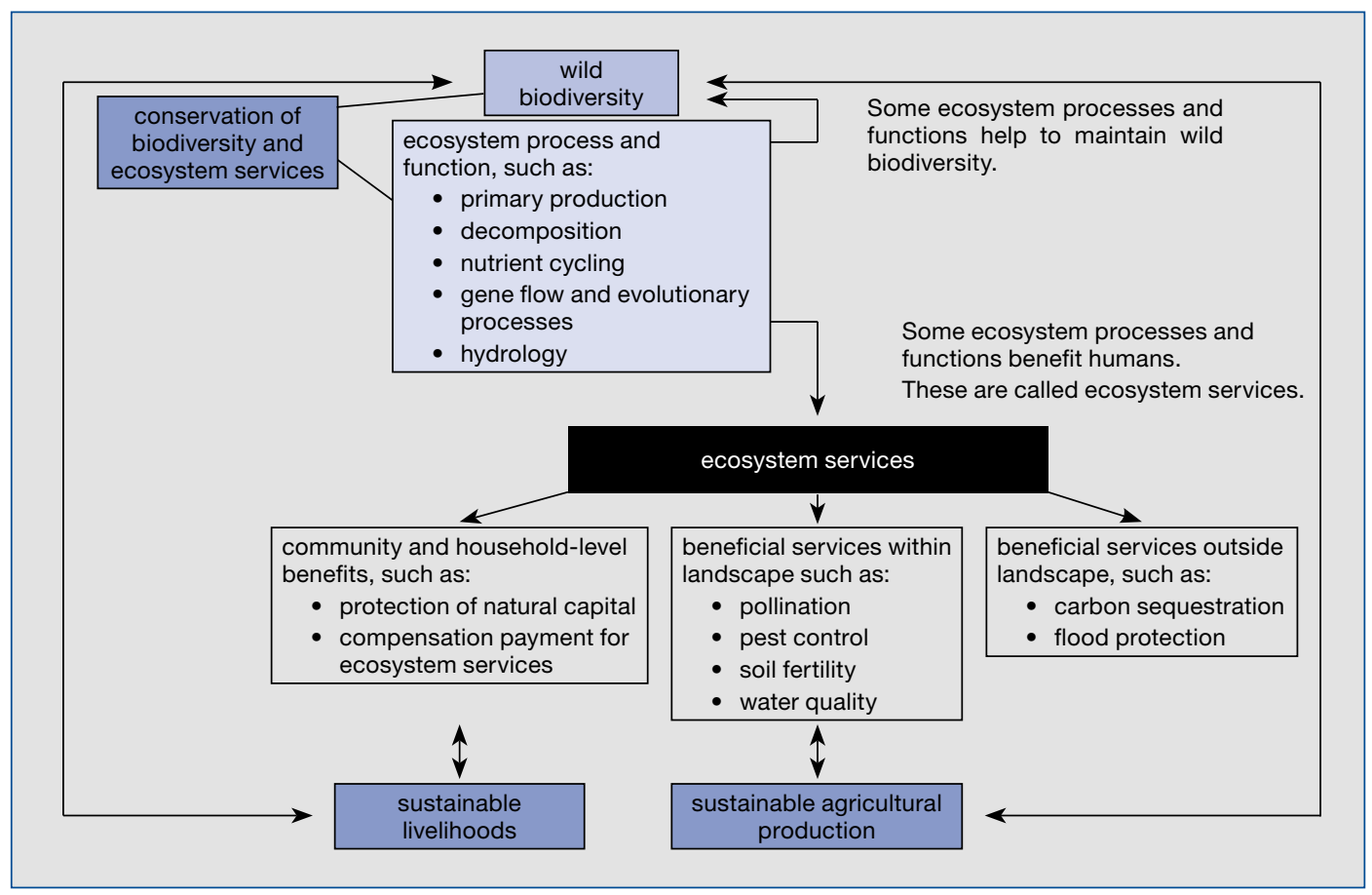

Figure 6.1 Ecosystem services for sustainable agriculture and livelihoods

(Source: Scherr \& McNeely, 2007, p. 481)

\subsection{Cross-cutting elements in policy and law}

This section explores several cross-cutting elements common in most legal frameworks and how they relate to spatial planning needs. Such elements could, for example, be reflected in provisions on goals and objectives, coordination, capacity building, monitoring and enforcement. Each element noted herein begins with overview comments followed by suggestions of specific options for actions that might be considered to support that cross-cutting issue. The critical point to stress is that these are points are presented as options. They are offered as ideas only; each country and legal system should choose which ideas may work best for their needs and fit within the traditions of their legal, political, and social systems. It is not intended that each and every option will be feasible or appropriate in a particular legal and policy setting. The options offer a wide variety of diverse ideas to give a sense of a full spectrum of possibilities and the scope of different choices, some of which overlap or are similar across elements. Many may not be appropriate, feasible, or timely for particular situations. Planning authorities, legal advisors, conservation practitioners, and policy-makers should consider them in that context.

\subsubsection{Spatial planning frameworks}

Spatial planning frameworks are a key starting point and an important policy tool in the planning process. Successful sustainable development requires forward planning, a vision, concrete goals and action plans on how to achieve those goals. A comprehensive spatial planning framework composed of spatial and sectoral plans at various levels of governance can help provide the structure 
and guidance needed to support regional and local initiatives, promote coordination and incorporate specific objectives related to climate change and biodiversity. Clear mandates promote and enable more successful implementation.

\section{Options for action toward building an overall planning framework:}

a) Develop a hierarchical planning framework and governance model of central coordination, regional visioning and local implementation. Enact comprehensive integrated spatial plans that pursue planning at a state/provincial, regional, and local level. Higher level policies and plans should provide a strategic framework to support regional and local initiatives and promote local and regional coordination. They should provide a long-term orientation and lay out vision for spatial development. They should also offer guidelines and procedures for establishment and implementation of planning documents. Plans should get progressively more detailed as they get closer to local level because impacts, capacity and solutions are different in each community or region. Arrange spatial planning framework such that each tier of government is able to represent its own spatial interests as effectively as possible. For instance, municipalities should be responsible for the municipal spatial policy and the municipal zoning scheme, which is legally binding for citizens. As soon as state/provincial or national spatial interests are affected, states/provinces and the national government should have similar instruments at their disposal to safeguard and protect these interests. Carefully interlink planning levels.

b) Indigenous and traditional rights should be recognized in spatial planning and management. Spatial plans must recognize and accommodate the existence of indigenous and traditional communities and land title, or resource tenure rights. Develop a national strategy and policy that enables indigenous and traditional peoples to acquire and manage land/marine resources to achieve economic, social or cultural benefits.

c) Require regional and local governments to develop climate change plans. Such plans could: (i) quantify greenhouse gas (GHG) emissions located within their borders; set out emissions reduction targets and timelines; allocate responsibility; and develop strategies to achieve targets; (ii) identify populations, areas and sectors (e.g., agriculture, water, coastal, marine, infrastructure, etc.) of highest climate vulnerability; set targets and timelines for reducing vulnerability; allocate responsibility; and develop strategies to achieve targets; and (iii) incorporate water use efficiency, integrated flood management, and enhancing ecosystem resilience. Climate change plans should be prepared in coordination with national plans and other spatial regional and local plans, including those relating to transportation plans, watershed plans, protected area management plans, other conservation plans, and infrastructure/ asset management plans to insure climate change considerations are incorporated into those plans and strategies as well.

d) Require regional and local governments to prepare biodiversity plans or strategies appropriate to their areas. These could identify: (i) priority areas for conservation action and the establishment of protected areas; (ii) ecosystems in buffers or corridors linked to protected areas; (iii) ecosystems that play an important role in the provision of ecosystem services; and (iv) ecosystems likely to be important for ecosystem-based adaptation to climate change. Biodiversity plans should also provide for regional co-operation. Any regional and local biodiversity plans should be compatible with National Biodiversity Strategies and Action Plans, 
and other relevant plans dealing with spatial issues, including those relating to transportation plans, watershed plans, protected area management plans, other conservation plans, and infrastructure/asset management plans to ensure climate change considerations are incorporated into those plans and strategies as well.

\subsubsection{Promote integrated planning}

An example of how spatial policies and laws can seek to integrate the relevant sectoral interests is by requiring that the different sectors communicate in the planning phase and that they consult with the relevant stakeholders across sectors. An example of how spatial policies and laws can seek to integrate the different policy and legal layers involved is to require the local and national levels to have increased, regular consultations and the national level to take stock of international commitments and best practices within neighbouring countries, in particular with a view to transboundary effects on the environment.

\section{Options for action:}

a) Create an overarching planning framework (as explained above) at national or regional level that integrates urban and rural lands, as well as special use lands (e.g. protected areas), and coastal and marine areas where applicable.

b) Identify cross-cutting spatial planning strategies and prioritize strategies that involve synergies. Examples include strategies that reduce emissions, protect public health and reduce traffic congestion or strategies that enhance resilience to climate impacts and protect food security.

c) Ensure social, economic and environmental considerations are considered in the development and review of planning policy and practice, including climate change and biodiversity. Link planning decisions with food security, health, poverty reduction and sustainability.

d) Respect, seek and use the knowledge of local people in the development of policies and plans and throughout the planning process, including for lands that may fall outside of traditional territory.

e) Involve environmental, climate change and biodiversity authorities in every stage of the planning process. Create climate change and biodiversity secretariats within relevant ministries or hire climate change and biodiversity specialists in spatial planning departments.

f) Promote and ensure public participation in spatial plan development by enshrining principles of public participation in planning law. Actively engage key stakeholders and interest groups through communication and outreach efforts. Make best efforts to engage rural areas and marginalized communities. Establish effective and ongoing public involvement processes to identify and prioritize mitigation, adaptation and biodiversity conservation options. Facilitate and emphasize early participation, which means consulting the public and stakeholders at a stage when there is still room to opt for alternatives and when the planning institutions have not yet firmly committed themselves to certain solutions.

g) Provide an opportunity for comment on draft spatial plans. Specify a process of consultation, exposure of draft plans, ratification and implementation. Hold public inquiries or consultations to discuss comments and responses. Consultations could be announced via local newspapers, public radio and government websites. The government can also decide 
to individually inform owners of implicated parcels. Disseminate draft laws, regulations and plans through various media for providing comments in a specific period (usually 30-90 days). Draft plans should be available in every community hall of every local community located in the planning area, as well as available online. Specify obligations for adjusting plans to reflect consultation. In case the government does not sufficiently take into account the comments, allow the approved plan to be challenged before an administrative body by any interested party.

h) Develop guidance for public participation and how it should be meaningfully implemented with objective standards for evaluating the effectiveness and integrity of implementation of participatory rights. Ensure there are formal rights of administrative appeal against sub-standard implementation of participatory rights.

\subsubsection{Mainstream climate change and biodiversity}

A clear policy framework that harmonizes climate change and biodiversity-related objectives and terminology can help overcome barriers to design and implementation of integrated planning systems. Developing and adopting strong objectives for adaptation and mitigation and mainstreaming climate change into management and decision-making at all levels of government are important steps in achieving improved climate change and biodiversity outcomes. Regulatory and technical guidance from multiple government levels on incorporating climate change and biodiversity into planning frameworks is important solicit as a basis to motivate collective action and help identify synergies between mitigation, adaptation and species protection goals.

\section{Options for action:}

a) Mainstream climate change and biodiversity across spatial policies, plans and management decisions. Update related laws, regulations and planning principles to integrate climate change and biodiversity considerations. Mainstream climate change issues into impact assessments and adaptation planning. Incorporate flood risk and sea-level risks in maps and advisory arrangements, and in consent conditions for developments. Harmonize across sector laws and align terminology across laws, policies and plans.

b) Adopt clear objectives for climate change mitigation and adaptation and biodiversity within spatial plans. Expressly name biodiversity and climate change as distinct planning principles that need to be assessed and considered in the planning process and resulting plan.

c) Harmonize spatial plans with climate change and biodiversity strategies. To the extent that jurisdictions have climate change or biodiversity strategies, these should be taken into account when developing or revising spatial plans. Local governments should focus on climate change adaptation strategies as part of their spatial plans. Require that planning authorities:

1) assess a proposed spatial plan's impact on climate change and biodiversity before it is adopted;

2) take into account protected areas and associated conservation areas;

3) consider alternatives that mitigate greenhouse gas emissions; and

4) incorporate adaptation measures to address the impacts of climate change during plan development. This analysis should be included in the spatial plan's explanatory memorandum, where such a memorandum is provided. 


\subsubsection{Coordination}

Agencies and individuals involved in spatial planning need to communicate and coordinate wherever possible. Vertical coordination (across different scales and levels of government) and horizontal coordination (across sectors, jurisdictions and governmental departments) are critical. Good coordination will allow flexibility, effectively shifting between various levels of government to identify avenues for solutions, harness efficiencies and avoid constraints. Climate change and biodiversity responses are most effective when implemented at multiple scales and across departments and sectors.

It is important to keep a number of legal considerations in mind:

1) There should be a legal basis for a certain type of action before an agency or institution involved can take up a mandate to coordinate certain policy areas. For example, the Ministry of Environment only has a certain competence because of the legal basis. If this legal basis does not include any action on climate change, for example, then the agency will not on its own take legislative action.

2) The legal basis should not be an after-thought, but should be well built to include a possibility to issue licenses during the planning phase that are well thought out and include coordinating responsibilities for the agencies and parties involved.

3) It should be made clear in the law how the coordination should happen, rather than the law making the process more lengthy and time-consuming, it should be transparent, clear, and not overly beureacratic on how such coordination is to be achieved.

\section{Options for action to facilitate coordination:}

Vertical Coordination (among various levels of government)

a) Require alignment of local level spatial plans, zoning schemes and planning- related decision-making with higher level spatial plans within a specified timeframe. Planning levels should be carefully interlinked and each lower level plan should take into account upper level plans.

b) Promote strong regional governance to effectively align growth management, cooperate on future climate scenarios and responses and coordinate development, implementation and enforcement of spatial plans. Consider creating a National Spatial Planning Commission, or something similar, tasked with coordinating all activities related to planning at national, zonal, regional, district and village levels.

c) Consider creating an independent indigenous or traditional rights council or similar mechanism (where there are indigenous or traditional groups, if one does not already exist) to provide information and assistance, make decisions, review and mediate native title applications and spatial planning agreements.

\section{Horizontal Coordination (among governmental departments/sectors)}

d) Require consultation with all relevant governmental departments prior to the formal adoption of the plan, including municipal or district authorities competent in matters of social welfare, public health, safety and the environment. Hold official or encourage unofficial meetings of regional and state/provincial planners to exchange knowledge, experience and ideas. Use a collaborative planning and decision-making process. Multidisciplinary panels, working groups and task forces are common ways to ensure cross-sectoral coordination and collaboration. 
e) Consider establishing a ministry responsible for planning and coordinating development activities. If that is a feasible option within the government policy and administrative framework, create legislation that provides such ministry with authority to consult with and negotiate aspects of other ministries' development planning agendas that are compatible with the overall integrated plan.

f) Require alignment between content of spatial plans and other relevant environmental planning instruments. In particular, this should include conservation-related plans, protected area management plans and system/network plans (both land and sea), connectivity conservation plans, and Strategic Environmental Assessments.

\subsubsection{Data, mapping, forecasting and modeling}

Baseline studies are important in a range of fields related to the needs of spatial planning. They involve the collection of information on regional and local land/sea/resource utilization, socioeconomic conditions and cultural heritage, as well as environmental aspects such as air quality, water studies, flora and fauna biodiversity and landscape/seascape. The use of data and modeling helps overcome subjectivity and discretion in the hands of single ministries whose loyalties may traditionally be split between conflicting interests (e.g. urban development versus environmental protection). With respect to climate change and biodiversity specifically, the mapping of current baselines and potential impacts also enables decision makers to conduct better risk assessments.

As discussed in Chapter 2 above, there is a growing body of information collection programmes, including remote sensing systems, that are generating data and analyses about baseline conditions of land and sea areas as well as current uses, including urban spread, vegetative cover, drought and flood areas, pollution, and changing features. Many such data bases are managed by government agencies and are available at little or no cost to other governments. Networks for sharing earth data, biodiversity, and climate change scientific information also are growing and should be explored by public sector planners and conservation practitioners. The options below offer specific ideas.

\section{Options for action to strengthen data collection, mapping, and use for planning:}

Data

a) Support and invest in science and research to understand future changes. Consider creation of a spatial information council or similar advisory mechanism. Create a spatial information framework where government agencies can collect and share data about biodiversity, climate change, threats, and the condition of current resources and land/sea areas. Where governmental data is not already available, turn to secondary source information from private organizations, other public institutions, universities, research centers and NGOs. Collaborate and coordinate on research including climate data, impacts and technology and build formal and informal partnerships with academic and business communities.

b) Create a central spatial planning database that includes up-to-date information on biodiversity, the effects of climate change, future climate scenarios and climate change projections and make these available for decision making. Build support and integrate existing monitoring networks to bolster baseline data and assessment tools. Develop a free, online resource that provides baseline information on biodiversity as well as information on the impact of climate change in different regions and possible adaptations. 
c) Require the use of baseline data on climate impacts and vulnerability assessments in spatial planning. Identify baseline periods (e.g. 1961-1990; 1991-2018) to use to define present climatology, allocate resources or to benchmark changes in climate or species risk. (Recall that the latest IPCC assessment came out in 2014 and provides the most current global and regional data; the next full assessment comes out in 2022, with special issue reports periodically.)

Assessments should be increasingly region-specific, sector-specific and quantitative as better tools become available. Assess vulnerability of infrastructure (starting with public infrastructure) and operations to past extreme events and future risks based on projected climate scenarios. Assess both severity of projected climate change impacts (present and as they intensify in projections) and resilience of an impacted sector to climatic trends and weather shocks. Prioritize vulnerabilities according to vulnerability assessments and the plan or strategy's decision-making process. Collaborate with academic and other local governments at the regional level on future climate scenarios, climate impacts research and development of potential adaptation responses and implementation plans.

d) Develop a comprehensive database on biodiversity that allows people to contribute information on species sightings, which improves knowledge and can assist with controlling the spread of a diseases or pest species. Allow a range of organizations to contribute including Government departments, universities and museums.

e) Adopt policies and supportive laws, as needed, to provide public access to environmental and planning-related information. Access to environmental information being used for government decision-making should be free of cost, to the extent feasible, and open to all legal entities and individuals.

\section{Mapping}

f) Use maps in spatial planning at all levels. The scale of detail can vary depending upon the plans at issue and available. Mapping and area designations should be based on clear criteria and established techniques.

g) Create an Office of Mapping within the relevant planning ministry. The Office of Mapping responsibilities could include: (i) maintaining a "map data bank" portal to access all maps prepared by public authorities; (ii) producing the maps for development plans and upper scale plans, upper scale cadastral and topographic maps; and (iii) controlling mapping standards.

h) Develop interactive mapping and decision support tools with data layers including baselines.

i) Require local or regional governments to map areas susceptible to climate change impacts such as major landslides and floods, sea level rises and identify vulnerable populations as part of their spatial planning processes. Maintain updated mapping of hazardous lands and sites (including buffers) to designate appropriate zoning for these areas in local planning documents. Work to ensure vulnerable populations with limited capacity or those who are living in especially vulnerable locations are known and protected from impacts of climate change.

\section{Forecasting and Modeling}

j) Base spatial planning on best available climate science, models and projections. 
k) Use locally-scaled climate data, where available, to allow users to visualize what climate change impacts are anticipated for their region and community under a number of different future scenarios. Plan based on future projections of various climate scenarios. Set up and maintain a clearinghouse of up-to-date climate projection data. Develop and use regional and local climate models to project changes in global temperature, rainfall, sea level, other earth system properties and project local mitigation and adaptation scenarios.

\subsubsection{Implementation}

A legislative framework does not always translate into successful spatial planning or the achievement of climate change and biodiversity objectives. Smart and effective implementation strategies are also necessary. Planning authorities should prioritize strategies that are realistic, impactful and aligned with local interests and capacities to maximize implementation success. Detailed education, guidance and training should also be provided to both planning authorities and the public to ensure policies are properly and effectively implemented on the ground.

\section{Options for action to strengthen implementation:}

a) Prioritize strategies that involve synergies with other objectives (e.g. air quality, water quality, traffic congestion, human health). Undertake a prioritization exercise to identify short term, medium term and longer term planning goals and priorities.

b) Identify locally-appropriate action. Higher level governments should, as a general rule, depend primarily upon local governments to implement spatial plans, subject to direction and oversight from higher-level agencies. It is best to ensure strategies are in line with local priorities and capacities.

c) Ensure revenue sources for plan implementation are identified and diverse. Specifically allocate a portion of the budget to spatial planning processes and set aside funds to achieve related goals. For effective implementation, plans need to be properly costed and closely aligned with the budget cycle.

d) Provide climate change and biodiversity-related guidance, outreach, training and funding to local authorities to enable the implementation of the recommendations discussed herein. Develop guidelines, education, technical training and toolkits in the form of publications, visualization tools and interactive web tools. Provide technical assistance and technical oversight and monitoring for implementing bodies or individuals. Government and other enforcement authorities should be required to undergo mandatory training before they are granted authority to issue permits. Facilitate resource pooling and information sharing among local governments.

e) Provide training and disseminate information more broadly to other players in the spatial planning process (e.g. landowners, resource rights holders, developers, conservation groups). Bundle legal tool implementation with public education. Improve ecological literacy by explaining benefits of biodiversity to public and securing stakeholder buy-in.

\subsubsection{Monitoring, reporting and evaluation}

For effective implementation, spatial plans need to be anchored in a results framework. Targets, timelines, designated actors and performance indicators are important components of spatial planning strategies. Monitoring and evaluation of both the planning effort to enact climate change 
and biodiversity responses, as well as the adaptation, mitigation and biodiversity responses themselves are important. A results-based framework sets planning expectations, forces authorities to define "success" and monitors whether and how planning is achieving that success. Consistent monitoring and evaluation also provide the opportunity for adaptive spatial planning, building in the ability to choose the most impactful course. Establishing pathways that allow for course corrections is important in long-term strategic planning.

\section{Options for action to support monitoring, reporting, and evaluation:}

a) Establish a performance management scheme and prescribe indicators and targets to assess compliance with each level of planning authority's development priorities and objectives.

b) Set specific, science-based climate change and biodiversity-related targets in spatial plans (e.g. GHG emissions reduction targets, rates of deforestation targets, biodiversity loss/ preservation targets, ecosystem conservation targets). Review, assess and potentially ratchet up targets during each spatial plan review.

c) Incorporate quantitative and qualitative climate change and biodiversity-related indicators into the performance monitoring frameworks for spatial plans. The portfolio of indicators for assessing success should include both process and outcome-based indicators in order to capture the benefits of each approach.255 In designing the indicators, ensure the indicators work on a municipal scale but can also easily roll up into a regional reporting scale. Combine species monitoring with performance indicators. Example indicators could include:

i. \% of population living in floodplains or low-lying coastal zones

ii. \% natural cover within the region

iii. \% urban forest cover within the built boundary of urban areas

iv. \% native forest and sustainable agriculture in rural areas

v. hectares of green space (within urban boundaries) per 100,000 population

vi. \% of land or sea space in protected area status in the region

vii. \% of household food basket that is local

d) Require planning authorities to continuously monitor plan implementation and spatial development. Create a regional or nationwide continuous spatial monitoring system to observe spatial development and collect and disseminate relevant information to planning authorities to feed into spatial planning decisions and revisions. Allow for sufficient implementation time before starting to monitor and evaluate.

e) Require planning authorities to report on performance indicators and plan implementation periodically (e.g. every 3-5 years). Compel the authority tasked with developing and implementing spatial plans to: (i) prepare regular reports detailing the status of plan implementation, the effectiveness of spatial plans and whether plans are in line with actual developments; (ii) submit reports to the relevant planning authorities; and (iii) review the relevant plan where necessary.

f) Build regular reviews of spatial plans into planning legislation or the plans themselves. Draw on plan implementation and performance indicator monitoring to revise plan objectives or targets as needed. 


\subsubsection{Compliance and enforcement}

Policies and plans that incorporate climate change and biodiversity considerations are excellent first steps but strong enforcement and compliance mechanisms are needed to ensure that high- level objectives are translated into local action. Legal requirements and financial incentives (discussed more below) can help motivate public behavior. In addition, administrative simplicity and an array of different kinds of fines, conditions, future limitations, and other penalties can be used to ensure private individuals comply with plans and further advance spatial planning goals. In addition, education programmes to the local communities, especially conducted by trusted local leaders and experts, can help convey the benefits of the policies and plans for their situations and promote selfcompliance and self-enforcement.

\section{Options for action to promote compliance:}

a) Have local governments undertake spatial planning. With training, necessary equipment, and technical support from higher level authorities, put responsibility on the local governments to undertake planning and plan implementation for its jurisdiction (pursuant to the subsidiary principle), following the higher level planning requirements, as required, and connecting adequate performance of these duties to other services being provided as a disincentive for failure. Alternatively, encourage local planning by providing local governments economic incentives to conduct planning (see more below).

b) Require public authorities to comply with spatial plans requirements for development once they are put in force, particularly in project permit decisions. Authorities should not approve projects that are not in line with spatial plans. Allow interested parties to challenge administrative decisions relating to permit or license issuances that allegedly violate spatial plans or other related legislation.

c) Condition government funding or international aid on inclusion of climate change and biodiversity considerations in long-range planning and development projects.

d) Enable duly authorized planning authorities (e.g., village, district, municipal provincial, or national agencies) to issue contravention notices where they have reasonable grounds for suspecting that a person has committed an offence under the respective planning legislation. These laws should call upon the person to remedy his/her non-compliance within a certain prescribed time period or face penalties.

e) Enable planning authorities and local authorities to bring enforcement actions against permittees or licensees alleged to be in violation of the spatial plans or seek a court order compelling compliance in the event of non-compliance with a contravention notice. Interested or affected parties (e.g. neighbours, NGOs) should also be able to file a complaint, which could lead to prosecution.

f) Provide for an array of disincentives, including administrative and potentially criminal penalties, for spatial plan violation and clearly articulate legal sanctions for violation of planning rules and procedures. Planning authorities should be empowered to take administrative measures such as: suspensions of activity; withholding or invalidation of permits or licenses for activities not in conformity with spatial plans. Administrative fines are also possible but less desirable given the potential for corruption. Violations of the spatial plans (as well as building permits) could also lead to criminal sanctions, imposed by a judge, including financial penalties and even imprisonment. 
g) Prescribe novel offence and penalty provisions for spatial plan violation that are more in line with spatial plan goals, including provision for environmental remediation, land/marine restoration orders and community service.

h) Create a central register of violators.

i) Encourage compliance with plans through simplified administrative procedures and incentives. Simplify administrative procedures and reduce red tape to facilitate compliance with the recommendations herein. Produce simple and short written guidelines on administrative procedures. Specify time limits for document processing and decision-making. Consider incentives such as tax reductions or accelerated document processing (e.g. permits and licensing) (see below).

\subsection{Highlights of subject-specific laws and policies}

Finally there are a variety of specific policy and law tools in most legal systems that can be used, directly or indirectly, to support and advance spatial planning processes and plans for biodiversity and climate change. Several also may be drawn upon to motivate environmentally-sensitive management of existing uses. These include regulations, development controls, incentives and disincentives, tax policies, and market-related policies. Many such tools can be combined with voluntary conservation agreements between governments, landowners or rights holders to undertake certain defined conservation practices, commonly with agreed incentives that may involve payments, technical assistance, equipment or other support. (Voluntary conservation agreements are dealt with in depth in Lausche, 2011)

It should be stressed that law and policy instruments for protected areas and other conserved natural and cultural areas governed by local, indigenous, or traditional communities are valuable foundation pieces for planners and policy-makers in spatial planning. This status extends as well to other demarcated conservation areas such as those for connectivity conservation or those being managed with other effective conservation measures. Such conservation-based legal designations provide authority to planning offices for automatically delineating these natural and cultural areas for special protections. Using an ecosystem approach, these laws and their associated objectives and incentives may also motivate restoration and active management of land or sea areas by landowners and rights holders to protect threatened species habitats, restore valuable ecosystem functions, or otherwise safeguard valuable natural sites or natural resources in order to advance overall sustainable development goals.

With that background, the remainder of this chapter highlights some of the specific legal tools available in most countries that can reinforce and support integrated spatial planning for biodiversity conservation and climate change.

\subsubsection{Zoning}

Local governments typically use zoning as a tool to implement spatial plans. Spatial zones broadly determine permissible activities (e.g. commercial or residential) and the required standards (e.g. building size and location) applicable in each zone. Zoning laws can thus be used to achieve a spatial plan's biodiversity and climate change objectives through methods such as directing growth in such a way that reduces urban sprawl and curbs transportation-related emissions; designating environmentally-important areas for environmental services or critical species habitat; delineating 
hazard areas to protect vulnerable communities; protecting food security and ecosystems; and limiting impervious surfaces, which reduces flood risk.

\section{Options for actions to support zoning for biodiversity and climate change objectives:}

a) Contain urban growth through zoning and strict, clear boundaries. Use zoning regulations to establish strict urban growth boundaries that restrict growth or concentrates growth within existing settlement areas that already have adequate infrastructure to prevent sprawl. Use of undeveloped space should be minimized and potential for further densification of existing settlements and brownfield remediation should be explored.

b) Require local planning authorities to use updated mapping of hazardous lands and sites to identify high-risk or hazardous areas relating to flooding, forest fire or other events and limit development in those areas. Require any new or revised zoning schemes to consider rising sea levels and designations of flood zones. Establish set-backs and buffer zones around high-risk or flood-prone areas and sensitive ecosystems. Update design and location standards and spatial designations based on vulnerability assessments of buildings and infrastructure. Locate public and essential services outside of hazard zones. Issue complementary development regulations that dictate, among other things, identification of land and buildings that require priority construction or development and potential relocation plans for human settlements found in high-risk zones.

c) Use zoning to establish and define parks, including urban parks, green spaces and other protected areas aimed to conserve, rehabilitate and restore natural systems and protect against climate impacts. Use local regulations to distinguish areas protected from development from those available for multiple use. Provide a list of spatial restrictions and designations that can be used in zoning plans, including: areas for conservation of soil, nature or landscape; areas for water management; obligations to plant bushes, trees or other plants; areas for offset measures from the nature conservation intervention regime. Prioritize the restoration of wetlands and retention areas in coastal areas and along rivers due to heightened flood risk.

d) Use zoning to preserve and enhance agricultural land. Foster and support local food production and work to reduce travel distances for food. Develop a spatial order in which agriculture and horticulture contribute their share to protect green infrastructure and species habitats in rural areas. Promote diverse types of eco-agriculture landscapes to generate positive co-benefits for production, biodiversity (including ecosystems), and local people. When designed and managed also to host biodiversity, agricultural lands' contribution to carbonsequestration and food security could also be recognized in spatial plans.

e) Allow zoning plans to determine emissions thresholds for certain plots of land where there are high levels of emissions, e.g., traditional energy power and manufacturing plants.

f) Require assessment of new or revised zoning scheme impacts on protected natural habitats and protected species, including "external effects" of activities carried out outside the protected area. The zoning scheme should have regard to the conservation objectives of protected areas and other biodiversity-rich areas, including Key Biodiversity Areas. How these factors were taken into account could be detailed in explanatory memoranda provided along with new or revised zoning schemes. 
g) Encourage authorities to include a description of how citizens and civil society organizations participated in the zoning plan. Adopt a public participation procedure for preparation of zoning plans. The authority publishing the proposed zoning plan also should include, where feasible:

- a map visualizing the zoning area

- rules on use and building

- explanatory memorandum

- number of the dossier

- place(s) and time(s) where the documents referred to in the above items are available for viewing and consultation.

\subsubsection{Permits and Development Permit Areas (DPAs)}

A Development Permit Area (DPA) is a set of development regulations pertaining to a specific site or area. Any proposed development within a DPA requires the issuance of a development permit. The purpose of a Development Permit Area may be to protect development from hazardous conditions; protect agricultural land; protect the natural environment, its ecosystems and biological diversity; or establish objectives to promote conservation or reduce greenhouse gases, among others. Development Permit Areas can be used to require site-specific impact assessments in designated areas. As illustrated in the options below, such assessments provide the opportunity to require the consideration of climate change and biodiversity impacts prior to development and integrate climatesmart practices such as green infrastructure, flood, and sea rise adaptation standards.

\section{Options for actions to use specially designated development areas:}

a) Use Development Permit Areas to set guidelines that protect ecosystems and Key Biodiversity Areas from development. Consider prohibiting construction activities in designated environmental sensitive areas and require special permits in other designated areas with special zoning designations and requirements to protect the environment, including special landscape and pollution control safeguards. Require developers to apply for "variances" for permission to allow certain development in ways that may not strictly adhere to applicable spatial codes, where of high priority public interest, and subject to compliance with core environmental standards and conditions as necessary.

b) Develop clear, evidence-based and transparent criteria for the granting of permits and require consideration of a given project's impact on climate change and biodiversity. Prohibit government discretion to allow certain projects in violation of spatial planning principles, unless in an emergency situation and high public interest. Official registration of all permits should be required and the names of permit holders, as well as permit terms, should be published to ensure transparency of permit grants.

c) Use permitting authority and incentives to require water conservation, permeable surfaces, run-off control, urban forests or green infrastructure as part of developments.

d) Use Development Permit Areas to establish building and development characteristics for flood-prone and sea level rise areas. Potential requirements could include: (i) basing plans on data and methods informed by the best available climate science; (ii) building above the projected 100-year flood elevation (particularly in the case of critical infrastructure such as hospitals); or (iii) build to the projected 500-year flood elevation. 
e) Publish national, provincial, regional and local lists of ecosystems that are vulnerable or at risk and use Development Permit Areas to require EIAs before specific activities can be carried out in these areas. Identify and publish an accompanying list of processes or activities that pose threats to such ecosystems and thus require special environmental authorization only where there is an emergency or high public interest.

f) Streamline permit administration to encourage compliance. Consider creating rules for granting an all-in-one permit for multiple activities that possibly affect the physical environment. Enable members of the public and companies to use one transparent procedure to apply to one competent authority for a single one-stop-shop permit covering all activities such as construction, demolition, the environment and activities in deviation of the zoning scheme.

\subsubsection{Spatial restrictions}

Statutory spatial restrictions can be used where zoning and spatial plans fail to ensure strict protections for high-value ecosystems or hazardous areas. Spatial restrictions provide predictability in planning by imposing blanket restrictions without exception. Such restrictions eliminate the need for EIAs or the weighing of potentially competing interests because all forms of development are prohibited, regardless of permissions or projected environmental impacts.

\section{Options for actions to use spatial restrictions:}

a) Use spatial restrictions to prevent vulnerable settlements, transport and social service infrastructure in risk areas. Institute strict spatial restrictions to ban construction and development in flood-prone areas (i.e. exposed to empirical risk of being hit by a flood every 100 years) with no exceptions, and to areas vulnerable to storm surge and sea level rise in the near to medium term. Spatial restrictions must be observed not only by spatial planning or administrative agencies but also by relevant landowners and users.

b) Use spatial restrictions to protect retention areas. Prioritize the protection and restoration of wetlands and retention areas in coastal areas and along rivers due to heightened flood risk. This includes prohibiting certain industrial and other potentially polluting activities within or in an area of influence of those protected spatial areas.

\subsubsection{Environmental Impact Assessments and Strategic Environmental Assessments}

Environmental protection and pollution control laws often include an environmental impact assessment (EIA) requirement. An EIA is an assessment of the environmental consequences of a plan, policy, program or project prior to the decision to move forward with the proposed action. EIA regimes are generally triggered before certain listed activities requiring an environmental authorisation are undertaken. EIAs provide an important opportunity for government authorities to monitor, control and manage spatial as well as build in requirements to consider key factor such as climate change and biodiversity. A comprehensive EIA regime includes extensive provision for public participation throughout the process.

The Strategic Environmental Assessment (SEA) is another important tool for assessing impacts from development, in this case, providing a more strategic analysis through a formalized, systematic and comprehensive process of identifying and evaluating the environmental consequences of proposed policies, plans or programmes. An SEA might be applied to an entire sector (such as a national 
policy on energy for example) or to a geographical area (for example, in the context of a regional development plan).

The main distinction is that EIAs are undertaken at a project-based level, whereas Strategic Environmental Assessments (SEAs) are undertaken at a strategic level. The importance of the latter is rather under-estimated in spatial planning practice and should be enhanced.

\section{Options for actions to support EIAs and SEAs:}

a) Develop an environmental impact assessment process triggered when certain listed activities are undertaken, including those associated with specific land/marine spatial development and resource use applications. Listed activities should be those with potential environmental and social impacts or those capable of harming the environment. The system should be simple, streamlined and predictable with transparent, science-based criteria, clear steps for participation and set timelines to promote involvement and enable compliance. The information gathered through EIAs should feed into broader planning processes.

b) Require evaluation and disclosure of the climate change and biodiversity-related impacts of projects that trigger EIAs. Considerations could include assessing the project's contribution to emissions, how it is likely to be impacted by forecasted changes in climate or how it could exacerbate climate and biodiversity impacts in surrounding areas. ElAs should also draw specific attention to flooding, water shortages and salinization; health issues; decreased accessibility of major cities; decline in habitat quality; and vulnerability of infrastructure. Require more detailed EIAs and greater scrutiny for projects proposed on or near higher value lands or ecosystems.

c) Develop a strategic environmental assessment for sector plans and spatial plans of national or regional scope where specific development approaches for categories of land/ marine use are being proposed in order to assess the environmental implications along with the economic and social ones.

d) Require assessment of cumulative effects. Make cumulative effects an integral part of the SEA or EIA when preparing spatial plans from the earliest stage of such processes. This should be reflected in appropriate policy and law instruments, including how 'cumulative effects' is defined. When assessing cumulative effects on biodiversity, it is essential to use an ecosystem approach, including consideration of ecosystem resilience and interactions between ecosystems. This will help ensure adequate attention to future spatial needs for biodiversity, climate change adaptation, and long-term ecosystem resilience.

Cumulative effects may be positive or negative and may occur both spatially across geographic areas, and temporally over time. They may arise from a single development or multiple developments. Application requires a long-term view, taking into account global, national, regional, and local effects. As explained in a toolkit for assessing cumulative effects of spatial plans and development projects on biodiversity (see Land Use Consultants, 2006), cumulative effects include:

- effects that result from incremental changes caused by other past, present or reasonably foreseeable actions combined, e.g., noise, dust, visual intrusion; or several plans or projects which together have a cumulative effect; 
- effects that result from complex interactions, sometimes referred to as secondary effects, e.g., a project that changes the water table and thus affects a nearby wetland causing an effect on the ecology of that wetland; and

- where there is uncertainty the precautionary principle should be applied to ensure that significant effects are not overlooked in the assessment process. (Adapted from Land Use Consultants, 2006, p. 12.)

e) Require mitigation of identified climate change and biodiversity-related impacts and direct agencies to pursue least-damaging alternative. EIAs and SEAs should show how proposals will affect the environment and adjacent communities, and whether other alternatives would achieve project goals in a more sustainable way.

f) Encourage quantitative and qualitative assessments and financial valuations of natural resources as part of Environmental Impact Assessments. The assessment should consider: provisional services (food, water, forest products); regulating services (floods, water quality); cultural services (recreational, aesthetic, spiritual); and supporting services (soil, nutrient cycles).

g) Build compatibility between the various jurisdictions and legal regimes governing EIAs and SEAs to ensure a coordinated and efficient system.

h) Require public participation in the preparation of EISs, SEAs and, where relevant, the list of possible exclusions. Require project sponsors to include in EIAs and SEAs the minutes of meetings at which local people who are to be affected by a proposed project or strategic assessment were consulted.

\subsubsection{Economic and market-based incentives}

Innovative economic and market-based incentives can be used to assist in achieving climate change and biodiversity goals and objectives laid out in spatial plans. The following are some examples. (This aspect is covered in depth in Lausche et al., 2013, pp. 130-141.)

Tax benefits and charges can be used to encourage or discourage certain behaviors relating to land/marine uses that need attention for climate change and biodiversity conservation. Property tax benefits can be used as incentives to increase urban density and reward low-impact development, as well as sustainable fisheries, agriculture, or forest practices. Strategically-imposed charges can deter negative behaviors such as urban sprawl, while also creating a source of government revenue to fund other climate change and biodiversity-related programs.

Engaging local landowners and rights holders in conservation and sustainable use of land/sea resources through innovative contracting and compensation schemes can help to overcome government capacity limits with enforcement, increase public education and buy-in, and ensure the continued existence of particular species and habitats. Payments for environmental services can be used to promote certain conservation measures that help to support needed ecosystem services for the public, e.g., watershed protection for flood control and maintaining water supplies.

\section{Options for incentives to promote conservation with existing and future practices:}

a) Consider offering property tax and income tax benefits to landowners/rights holders who conserve or manage their land/sea resources in ways that help achieve climate change or biodiversity goals, including ecosystem resilience. Examples could include 
landowners/rightsholders whose land is designated as a protected area; landowners whose land offers significant environmental services such as carbon sequestration, ecosystem resilience, or water filtration; and landowners who agree to help implement biodiversity strategies or management plans on their land/marine areas. Require that the landowner/rightsholder maintain a duty of environmental stewardship and share the cost of managing such areas in order to be eligible for compensation. Consider using Reciprocal Environmental Agreements (REAs) or other innovative contracting tools to engage local landowners/rightsholders in spatial planning, implementation and management, and reward environmental stewardship through compensation (i.e., payment for environmental services). Seek out opportunities to partner with agricultural landowners/rightsholders to promote ecoagricultural landscapes to achieve multiple goals (e.g. climate adaptation and mitigation, biodiversity, local food security).

b) Give Incentives for low-impact development (LID) by waiving or reducing development cost charges for projects incorporating LID such as rain gardens, permeable pavement, bioswales and rooftop gardens.

c) Initiate programmes for 'Payment of Environmental Services' (PES). PES is a relatively new economic tool receiving increased attention for promoting voluntary conservation actions is a contractual arrangement whereby public authorities or private stakeholders provide landholders with payments for specific ecosystem services (for example, watershed protection to sustain water supplies) in exchange for the landholder undertaking compatible land and water management practices to secure those services. PES has promise with continued development to achieve desired ecological objectives and secure continuous funding over the long term.

\subsubsection{Biodiversity offsets}

Biodiversity offsets are incentive measures where developers are allowed to destroy certain defined species habitat or ecosystems (wetlands) so long as they restore equivalent space for equivalent environmental purposes elsewhere. This tool creates a market system for conservation that provides flexibility to planners and developers while aiming to achieve no net loss of species or habitat. However, the first principle of offsetting in application is that it should only be used as a last resort after initial steps have been taken to modify the development proposal on site so as to avoid or mitigate conservation impacts. A truly 'no net loss' outcome is rarely achieved in practice because of unique ecological features of each natural area and that can't be directly substituted and, in many cases, limited science about the full natural value of the site to be modified.

How biodiversity offsets might be used, taking account of the caveat above, to -

a) Implement a mitigation and offset scheme that requires parties to fully offset any encroachment on species and habitats. This scheme should apply to all land/marine areas, not just encroachments on conservation areas. Deforestation, wetland destruction, potential degradation of protected areas, destruction of important seagrass beds or coral reefs in marine areas which, in particular should lead to obligatory offsets in development permit areas if there is no alternative and the development project is fundamentally in the pubic interest. According to some analysts, the safest approach is creating or protecting at least three times that which is destroyed.

b) Include an option for biodiversity offset schemes as conditions attached to environmental authorisations granted under an EIA, but only as a last resort. 


\subsubsection{Protected areas and designations}

Designated protected areas are areas that receive heightened protection because of their recognized natural, ecological or cultural values. IUCN guidelines define protected areas that meet international standards for inclusion in the UN List of Protected Areas and also define and give guidance on the six management categories that translate into conservation objectives from strict protection to multiple use (see, Dudley, 2008/2013). Protected areas, especially those meeting the IUCN definition, are vital for biodiversity conservation and are recognized internationally as a front line tool for combating biodiversity loss (for an extended analysis of key elements for protected areas legislation for biodiversity and climate change, see Lausche, 2011).

An expansive network of formal land and marine protected areas, other conserved areas, buffer zones, ecological corridors and other connectivity areas, and areas managed for other effective conservation measures are critical components for an effective sustainable development strategy. Increasingly these many kinds of areas that make up such conservation networks or systems also will reflect a diverse array of governance arrangements (e.g., indigenous, traditional, and community conserved areas, private protected areas, shared or co-managed areas - see Table 2.5 above). These networks help build ecosystem resilience and provide an important opportunity, if properly managed, to help mitigate climate change through carbon sequestration and to aid species and ecosystems adaptation to climate change, as well as help improve water retention and flood control, among other outcomes.

\section{Options for actions to support maintenance and expansion of protected areas:}

a) Expand protected areas networks through the use of legal designations and protections, and for private lands the use of conservation agreements, covenants or easements. Establish a network of green and open natural or semi-natural spaces to support biodiversity connectivity, conserve natural resources and protect ecosystems. Aggregate protected areas into a single management system. Further fragmentation of biodiversity rich landscapes and seascape should be avoided.

b) Base protected area designations on clear criteria. For instance, new areas could be designed, strategically acquired and conserved according to specific guidance, including the IUCN Guidelines on Protected Areas Management Categories (Dudley, 2008/2013). In addition, criteria could include to -

i. Design the protected area system to allow for long-term species and ecosystem movements in response to climate change

ii. Keep natural habitat intact in ecological corridors (especially corridors along climatic gradients), which should be identified in spatial plans

iii. Grow the conservation estate in ways that are aligned with maximizing opportunities for connecting landscapes along altitudinal, latitudinal, or major drainage corridors and developing a climate-resilient network of protected areas and promoting greater ecological connectivity with a view to assisting the migration, maintenance and enhancement of ecosystem service delivery to support local communities in all sectors

c) Protective laws and regulations regarding protected areas and nature conservation should be strictly respected by spatial planning and should not be subject to weighing or other exemptions. Follow international guidance in the IUCN Guidelines for Protected Areas Legislation (Lausche, 2011) and Law and Connectivity Conservation - A Concept 
Paper (Lausche et al., 2013) for specific guidance on essential legal considerations and elements for protected areas and connectivity. In other areas with environmental values where uses may be considered, establish a clear hierarchy of uses (first priority of wildlife, plants, and habitat conservation; second priority of wildlife-dependent recreational use; third priority of compatible commercial use; etc). Commercial development, structures, roads and motorized vehicles should generally be prohibited.

d) Authorise establishment of buffer zones and connectivity areas to minimize or eliminate adverse impacts to specific protected areas and support movement of species and spatial elements of ecosystems, in both marine and terrestrial environments. Create core areas to provide strict protection to sites of high-value conservation and adjacent zones for other conservation objectives (IUCN categories I through VI). Designate buffer zones outside formal zones to provide transition areas around formal core areas. Buffers can serve as protective belts as well as connectivity areas for needed species and ecosystem processes not able to survive solely on the space within the designated protected areas. Buffer zones cushion protected areas from adjacent industrial, agricultural and other activities outside the designated areas. Require and develop guidelines for buffer zones and set-backs to secure the protection of the conservation site.

A range of ecological and socio-economic criteria should be used to establish buffer zones and other connectivity areas such as corridors. Local authorities should cooperate with protected areas authorities implementing protected areas laws to collaborate on development and implementation on appropriate buffer zone and other connectivity area management plans to safeguard connectivity needs. An environmental impact assessment should be carried out prior to any allowable activity in a buffer zone or formal protected area, or designated connectivity areas.

e) Require that all protected and other conservation areas have approved management plans that also integrate climate change aspects to enhance resilience of species and ecosystems (revised every 5-10 years). Protected areas law and management plans should graft additional protective spatial planning mandates onto existing spatial schemes. Develop an approach to landscape/seascape conservation planning with the mitigation hierarchy avoid, minimize, restore, or offset - to identify situations where development plans and conservation outcomes may be in conflict, and to identify which step of the mitigation hierarchy is consistent with conservation goals.

f) Enable the relevant minister to publish a national or state/provincial list of ecosystems that are vulnerable or at risk and require listed ecosystems to be taken into account in preparing spatial plans.

g) Solicit consultation, views, and recommendations from environmental and other NGOs, particularly local NGOs, in major decisions about nature conservation and the security of designated protected areas and their primary conservation objectives. This should include considerations of exemptions from specific conservation protections for areas other than for formally designated protected areas.

h) Consider opportunities for co-management or local governance of public lands and community lands designated as formal protected areas and other recognized conserved areas. Options may include co-management or sole governance of such areas by local communities, indigenous or traditional communities or groups, NGOs, private individuals, or corporations. 


\subsubsection{Compulsory acquisition}

Finally, among the law and policy tools available in most countries for implementing spatial areas is the option for compulsory acquisition of the land or resource rights at issue. This may be the only option in cases where the area is critical for implementing certain fundamental conservation strategies to conserve or restore resources for biodiversity or climate change needs, and there is an overwhelming public interest in doing so, including potentially for health and safety as well as long-term sustainable development. Essential elements for this to work effectively is transparency, evidence-based criteria, a clear definition of 'public interest' and a fair compensation scheme. It should be noted that this commonly is not a preferred option for governments but is used only as a last resort because of the potential for severe political and social back-lash.

\section{Options for actions supporting compulsory acquisition of property:}

a) Empower government to acquire areas and ecosystems strategic for the conservation, preservation and recovery of natural resources. Use this tool to acquire protected area, natural corridors, and areas critical for maintaining essential ecological processes to provide needed ecosystem services for the people. Any processes involving compulsory acquisition must be initiated with the application of Free, Prior and Informed Consent (FPIC) and the respect of fundamental human rights. Any proposed relocation processes must adhere to international human rights standards, respecting rights and mitigating and/or compensating for any negative material and non-material impacts.

b) Allow government to dedicate private land for public purposes - such as transport, infrastructure, green space, water services, flood protection and conservation of soil- when justified by public interest. Ensure that conservation, preservation and recovery of high ecological value lands, ecosystems and species fall within the definition of "public interest" such that the government is empowered to acquire these lands.

Develop clear, evidence-based, transparent criteria for determining when a property owner/rights holder is entitled to compensation as a result of government action limiting the use of or fully expropriating land. For instance, consider granting private property owners a potential right to compensation in the following circumstances: (i) when there is full government occupation or seizure of private property; (ii) when private property owners are required to open their property for public use; (iii) when regulations that deprives a landowner of all economic use of his or her property are put in place. Impose a time limit on landowners' right to compensation to allow for planning predictability.

\subsection{Key messages}

Many existing legal tools to start. As illustrated by the lengthy discussion above, which touches only the surface, a diverse array of substantive laws, and regulatory and incentive instruments is already available in most legal systems to use directly or indirectly to strengthen public sector spatial planning. Countries should start with what tools they have and, to the extent such tools permit, take measures to modernize their spatial planning processes and plan implementation, and where relevant being informed by the many issues and concepts discussed in this book. It is important to begin with what is possible now before such measures are no longer economically, politically, or environmentally feasible. The formal process of amending or enacting new legal instruments normally takes time and as time passes, some options will fall away for conserving 
biodiversity, building ecosystem resilience and dealing with climate change on the path to sustainable development.

While approaches vary, need legally-binding plans. There is no single best approach to strengthening public sector planning to be more comprehensive, integrated, and long-range. Rather, there are a variety of possibilities and options, each having different levels of relevance and feasibility for particular settings. Where feasible, however, legal instruments should provide explicit authority for undertaking integrated spatial planning processes and make the resulting plan legally binding in priority areas, including critical spatial needs for biodiversity conservation, building ecosystem resilience, and adapting to climate change.

Law and policy integration. This is one of the most challenging and potentially difficult areas for effective spatial planning. Especially in large-scale geographic areas, there are likely to be many uncoordinated and often overlapping or conflicting sectoral policies and laws across government levels impacting in different positive and negative ways. It is essential to identify and assess laws and policies in those sectors and, as needed, integrate and harmonize objectives and implementation to avoid conflict and counter-purposes. From experience, a useful institutional technique for crosssectoral and intergovernmental coordination is to authorize a lead agency from existing institutions or create a new coordinating mechanism with representatives from the key sectors and government levels involved. To build collaboration, compatibility, and broad participation and support from all concerned (government and other governance actors, stakeholders, and the public), it may be necessary to consider a phased approach to this integration process. 


\section{Special issues for marine spatial planning}

Not only terrestrial environments need spatial planning to guide human activity and development. Marine environments are increasingly under threat from expanding human use, use conflicts, and mismanagement, along with advancing climate change. Some marine resources and ecosystem services are already severely degraded. On a global scale, the health of marine and coastal ecosystems is declining and being increasingly threatened by overuse, pollution, and habitat degradation. Marine spatial planning is a relatively new planning tool for many countries, but the field is advancing rapidly and receiving heightened attention because of growing alarm over the deteriorating state of the planet's oceans and the critical role the ocean plays supporting and sustaining all life.

This chapter gives a brief review of special issues and challenges for spatial planning in marine and coastal environments that need to be taken into account in supportive law and policy. It builds on and should be read together with other chapters above on concepts, such as ecosystem-based management, and law and policy tools noted in chapter 6.

\subsection{Unique features of marine environments}

It has only been in recent years that science has made significant strides in beginning to understand the critical role of the ocean in supporting all life including biodiversity (much of which is still undiscovered). One is reminded in the literature that the ocean covers almost 71 per cent of the Earth's surface and contains roughly 97 per cent of the Earth's water (the remaining one percent in fresh water and 2-3 per cent in glaciers and ice caps). Overall, with its deep sea areas, the ocean contains about 99 per cent of the living space on Earth. Marine phytoplankton (the plant components of the plankton community) produces 50 per cent of the oxygen on Earth. Eight out of the ten most populous cities on Earth are coastal and over half of the world's population lives within $200 \mathrm{~km}$ of the coastline. Around 80 million tonnes of fish are caught annually by 3 million marine fishing vessels and more than $10 \%$ of the world's population depends on fisheries for their livelihoods. The U.S. National Ocean Service of NOAA has characterized this dependency in stark terms:

The ocean is the lifeblood of the Earth, ... driving weather, regulating temperature, and ultimately supporting all living organisms. Throughout history, the ocean has been a vital source of sustenance, transport, commerce, growth, and inspiration. (https://oceanservice.noaa.gov/facts/ exploration.html)

A significant, new scientific finding underscores the urgent need for marine spatial planning to control and manage human activities impacting the ocean. According to a 2018 IOC-UNESCO report, oxygen in the ocean is declining and human activities are a major cause (Breitburg et al., 2018).

Scientific assessments confirm that increasing demand for ocean resources has already led to extensive loss of marine biodiversity. The WWF Living Planet Index of 2015 found a 49 percent decline for marine populations between 1970 and 2012 of species already identified (WWF, 2015, p. 6). The 2015 IUCN Red List shows a growing number of threatened marine species while acknowledging as well that only a fraction of known marine species have been evaluated (see http://marinebio.org/ oceans/red-list-species/).

The ocean environment faces accelerating threats from human activity. Tensions over use of the sea (especially from conflicting or competing uses) have grown over many decades as demand for ocean 
space and its resources have expanded both for existing and new uses. Simultaneously, there is growing pressure to expand uses beyond national jurisdiction as new technologies are able to exploit newly discovered resources. Other major and increasing pressures facing the ocean environment include climate change, biodiversity loss, pollution from land and sea, over-exploitation, and illegal activities. Marine industries and land-based pollutants are creating ever greater impacts on the health of ocean ecosystems, direct exploitation is reaching deeper depths, and sectoral uses are overlapping-trends expected to continue (Census, p. 5).

Climate change is over-shadowing these threats with additional stresses on both the physical environment of the ocean (currents, vertical movement, etc.) as well as marine life. Warming seas, ocean acidification, sea level rise, dying coral, melting polar caps, shifting migratory patterns of marine life, and intrusion of invasive marine species into new areas without natural predators are all well-documented impacts from climate change. And still little is known about the long-term consequences for marine and coastal dependent economies (e.g., fisheries), extreme weather events, and the critical ecosystem services on which life depends. (For a discussion of spatial planning responses to climate change in marine and coastal areas, see Wilson \& Piper, 2010, pp. 300-314)

In 2010, the first ever Census of Marine Life (the Census) was concluded after 10 years of effort by more than 2,700 scientists from 80 countries (see http://www.coml.org/). An important finding there was the rich biodiversity in virtually all zones of the ocean and the valuable life-supporting, economic, and social benefits provided by the biodiversity of the ocean. Sustaining biodiversity for the important benefits it provides to humans is a significant reason to justify marine spatial planning. To give a sense of the ocean's complex spatial features, the Census also provided a theoretical cross section of ocean space (see Figure 7.1 below).

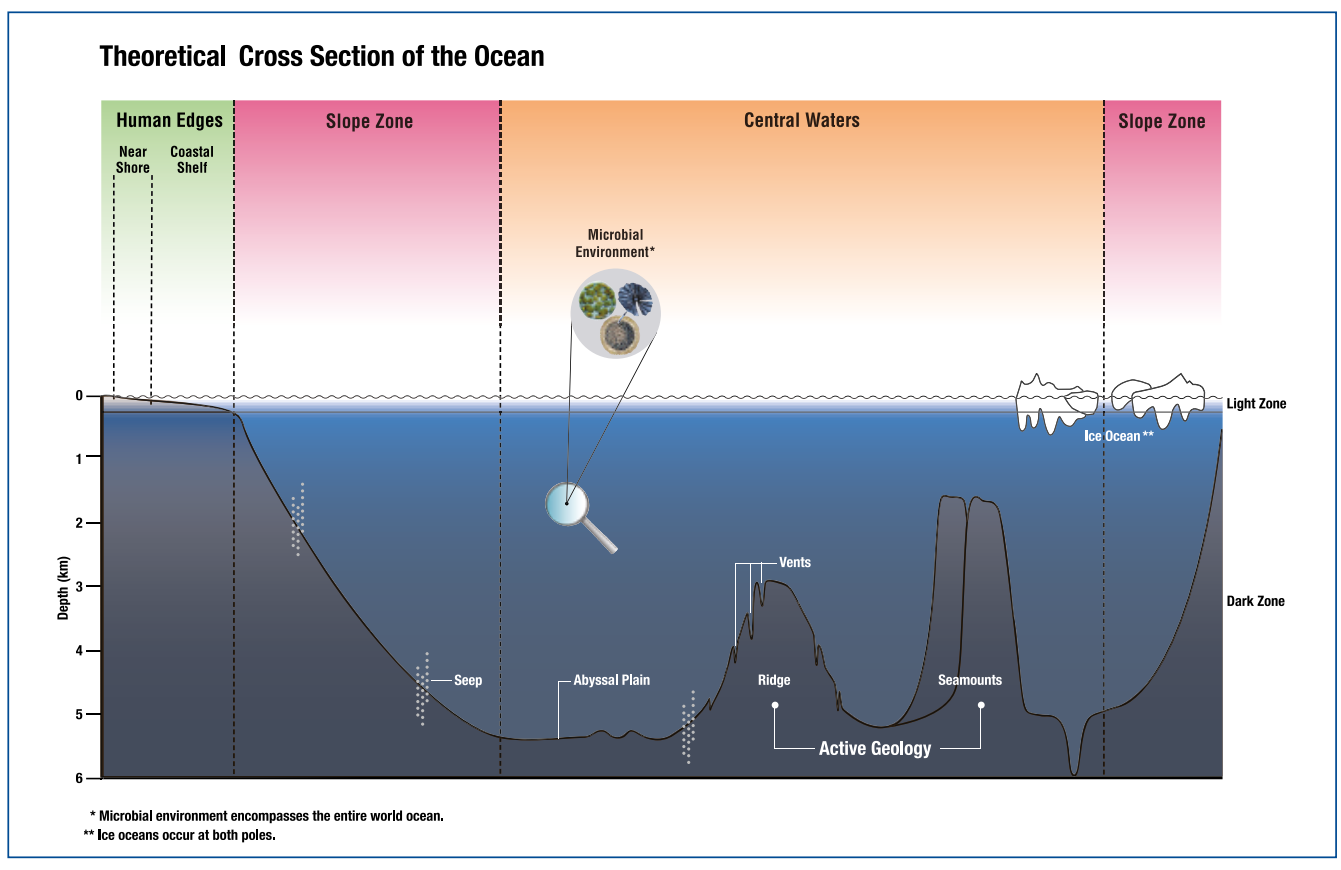

Figure 7.1 Cross section of ocean space

(Source: Census summary, 2010, p. 5) 
To achieve effectiveness, the marine spatial planning process and resulting plan must take into account the special features and obligations associated with the marine environment that distinguish it from the terrestrial environment (see Lausche, 2011, and Lausche et al., 2013 for extensive coverage of this issue). These features include the ocean's three dimensional space in which species and processes interact and move - the ocean floor, water column, and horizontally at different depths; new challenges for deep-water areas (depths below 200 meters); natural connections to coastal and land processes as well as areas beyond national jurisdiction, and different tenure regimes such as licenses and permits in addition to traditional rights of local communities and peoples. There also are international law obligations and commitments that countries have made concerning use and management of the ocean and marine resources which need to be taken into account in the marine spatial planning process and plan (main instruments are summarized above in Chapter 2, Table 2.4 - Part 3).

\subsection{Marine spatial planning in practice}

The field of spatial planning on land has had a much longer history of experience then spatial planning for the ocean. Each year scientific research, helped greatly by new marine technologies, is revealing how complex and dynamic are the ecological processes and interconnections between marine species and these processes throughout the water column, including in the deep sea.

Most countries already authorize activities in their marine waters for a variety of human uses, from oil and gas production and offshore renewable energy development, to offshore aquaculture and waste disposal. The problem, as with much land use planning, is that decisions are generally sector by sector, without much coordination or collaboration, and on a case by case basis. This results in decision-making that is piecemeal and reactive, commonly with limited options once individual problems and harm have occurred. Increasingly, countries are beginning to look to marine spatial planning to better harmonize decisions and work toward sustainable ocean use and management.

It was not until 2006 that the first International Workshop on Marine Spatial Planning was convened by UNESCO. In 2009, UNESCO's Intergovernmental Oceanographic Commission (IOC) published guidance on marine spatial planning that remains a foundation piece today. Entitled "Marine Spatial Planning - A Step by Step Approach toward Ecosystem-based Management", the publication lays out the key stages to undertaking marine spatial planning, from establishing authority, through planning to implementation, monitoring and evaluation. The guidance was prepared after finding an "explosion of interest" in marine spatial planning especially since the workshop and spreading, for example, to some countries in Western Europe and to places as different as the United States and Vietnam (Ehler \& Douvere, 2009, p. 6).

From that document came the initial definition of marine spatial planning that is still widely used today:

Marine spatial planning (MSP) is a public process of analyzing and allocating the spatial and temporal distribution of human activities in marine areas to achieve ecological, economic, and social objectives that are usually specified through a political process .... MSP is a practical way to create and establish a more rational organization of the use of marine space and the interactions between its uses, to balance demands for development with the need to protect marine ecosystems, and to achieve social and economic objectives in an open and planned way (lb., p. 18)

The definition one finds today in the IOC website is slightly refined but essentially the same, further elaborated into key components: 
Marine spatial planning (MSP) is a process of analyzing and allocating parts of three-dimensional marine spaces (or ecosystems) to specific uses or objectives, to achieve ecological, economic, and social objectives that are usually specified through a political process.

- MSP is a process that is:

- ecosystem-based (balancing ecological, economic, and social goals and objectives toward sustainable development);

- integrated across economic sectors and among governmental agencies;

- place-based or area-based;

- adaptive (capable of learning from experience);

- strategic and anticipatory (focused on the long-term); and

- participatory, with stakeholders actively in the process.

(http://msp.ioc-unesco.org/about/msp-facts/)

Finally, it is worth noting the working definition of marine/maritime spatial planning used by the EU when announcing the 2018 launch of the Joint Roadmap to accelerate Marine/Maritime Spatial Planning processes worldwide adopted the prior year (see EC, 2017):

Maritime Spatial Planning is the rational organisation of sea and coastal areas so as to cater for the different - and sometimes competing - needs of various economic activities (such as fisheries, aquaculture, transport, energy and so on) and to make sure thay are carred out safely and sustainably. It needs to be negotiated across sectors and across borders (EU press release, 25/05/2018).

\subsection{Major challenges for marine spatial planning law and policy}

In light of the special natural features of and threats to marine environments, effective marine spatial planning for long-term sustainability faces many challenges and these are exacerbated by climate change. A detailed discussion is beyond the scope of this overview. However, three challenges stand out as new and emerging issues being driven by advances in scientific knowledge about ocean processes and significant improvements in ocean observation technology. These challenges will put new demands on the scope and skills for marine spatial planning, and particularly the scientific and management practices needed to ensure effectiveness for conserving marine biodiversity, essential ecological processes, and critical life-support services from ocean ecosystems. These challenges also define the kinds of powers, responsibilities, planning components, and technical capacities that will need to be reflected in supportive law and policy. They relate to:

a) Long-term spatial planning for the vast water column of the ocean (the third spatial dimension that doesn't have an equivalent in most land use plans). Most challenging will be to understand limits and opportunities for development in the deep sea below 200 meters where biodiversity and ecological processes are less well understood but intricately linked across life cycle processes, and with adaptation and resilience not only for ever-expanding human uses but also for climate change. Law and policy needs to recognize this challenge but require attention to this dimension with the best available information and best available technology for monitoring and enforcement.

b) Taking account of natural connectivity between national and high seas waters, as well as between national waters and those of neighbouring states. Natural ocean systems connec- 
tivity is particularly complex in the large-scale, offshore deep-sea environments. Ocean currents, wind drifts, and species migrations create natural linkages between distant regions of the ocean and national deep waters. Ocean processes transport nutrients, food, seeds, larvae and organisms, as well as pollutants, across vast ocean and land-ocean areas. These processes are highly dynamic and subject to natural changes, sometimes rapid, without regard to political boundaries, including national marine boundaries. This scope needs recognition in law and policy.

c) Making full use of ocean observation technology, taking advantage of information networks, building skills and capacity to filter and interpret ocean data on processes and species that can be translated for use in marine spatial planning and for monitoring implementation. While there is still much unknown, advances in science and technology are rapidly helping improve understanding about the ocean's interconnected physical, biological, and chemical properties, unique biodiversity, and life-support functions. This growth of knowledge has been due in large part to significant developments in marine observation and computer technology to reach farther and deeper into the sea to record, collect samples, monitor and digitize almost all research data. It is important to recognize this in law and policy, in order to give legal authority and legitimacy to efforts by marine planners and practitioners to actively engage in and rely on use of digitized data, build skills and equipment capacity, and tap into ocean information networks as a key aspect of their responsibilities.

\subsection{Key messages}

Marine spatial planning at the national and bioregional level is essential to provide a scale of planning for management that can deal with site-specific issues. It is at the local scale where data collection, analyses and problem-solving happen, a focus not easily provided by the equally important international instruments guiding biodiversity conservation and ocean use. Global guidance and commitments must be translated into practical action on the ground through national policies and programmes, each level reinforcing and building from the other. Similar to land use planning and urban planning, modern marine spatial planning (incorporating the special issues, features, and challenges of marine environments) can provide order, stakeholder involvement, cross-sector collaboration and coordination, and predictability for multiple ocean uses while safeguarding ocean species, ecosystem services, and sustainability over the long-term.

Scientific understanding is improving about marine biodiversity and ecological processes at different depths of the water column, including the deep sea, especially in recent years with the help of new ocean observation and monitoring technologies. Marine spatial planning must incorporate the role of the water column in supporting species and ocean processes, as well as interactions with land processes and areas beyond national jurisdiction.

Education is essential to help policy makers and the public better understand the critical role of the ocean in supporting life. From the perspective of the public and many users, there continues to be little appreciation of the value of the ocean beyond what they use for recreation and see on the surface. For many, there is little understanding of the dynamic nature and complexities of the ocean, ecosystem services it provides, growing collapse of fisheries and marine habitats due to unsustainable, illegal and unregulated fishing, threat from other expanding uses such as drilling, oil and gas exploitation, and deep-sea mining, and finally the overwhelming threat from climate change. 


\section{Concluding messages}

Integrated spatial planning provides an overarching planning framework for all sectors and levels (from national and provincial to local), that has the potential to integrate urban and rural lands as well as special use land/sea areas (e.g., protected areas, conservation areas, ecological networks, coastal and watershed protection areas, sustainable agriculture/forest/fisheries areas ), connectivity needs, and subsurface areas.

Spatial planning should be grounded in law at all levels, and create clear criteria when, in special cases, exceptions may need to be granted following strong evidence, for specific development projects or variances, or added measures for conservation or sustainable use. Legally-grounded spatial planning processes and resulting plans also are important for attracting investment in sustainable development projects.

Start now using existing law and policy tools. Many policies (e.g., Aichi Targets, SDGs, specific convention obligations) already exist in most countries to support actions to strengthen planning instruments for more integrated spatial needs. This book could only highlight few of the diverse array of substantive laws. There also may be constitutional elements, and regulatory and incentive instruments that already exist in most legal systems. These can be used directly or indirectly to strengthen public sector spatial planning. Countries should start with what tools they have to begin to take measures to modernize their planning processes and plan implementation. The formal process of amending or enacting new law and policy normally takes time and as time passes, economic, environmental, and political options may be reduced. A two-pronged approach is needed: work now with what is available, and begin negotiations on areas for law and policy strengthening.

The right incentives, including fiscal incentives, along with a broad range of supportive policies, need to be used to support change in existing land/sea resource practices to be more environmentally sensitive and to facilitate stakeholder support of restrictions and conditions that may be imposed on future development of their lands or resources through the integrated spatial plan.

All levels of government, from national to local, must collaborate and coordinate on developing complementary and reinforcing spatial policies and plans for future development of land/marine resources in order to achieve sustainable development goals. This requires special effort to work across sectors as well. Today, spatial and land use policies are often coordinated across some policy fields, such environment, transport and housing, but not in others such as foreign affairs, defense, or finance. In the future, this coordination will need to become more systematic and include all relevant ministries or departments, including finance ministries.

Safeguarding the sustainability of land and marine resources matters because people are attached to the land and resources. In light of this, policies on use and planning may tend to be contentious, and conflicts may emerge. In part, this is because land/resource use decisions by an individual landowner/rights holder inevitably affects other people. As a consequence, spatial planning of land and sea areas and resources, both surface and subsurface, need to ensure participation of stakeholders based on fair, informed and open negotiation, and a balancing of public and private interests if the resulting plans are to be supported and survive in implementation.

Mechanisms for public participation should be developed to provide a systematic process and routine procedures that communities and stakeholders can rely upon for participation, as they 
choose, in any aspects of the spatial planning process. This information should be widely and regularly disseminated through communication tools that effectively reach the local level (press, radio, social media, etc.). Announcements about specific plan proposals or changes should be made sufficiently in advance for meaningful participation. It is important to make best efforts to engage rural areas and marginalized communities, and to facilitate and emphasize early participation when there is still room to opt for alternatives and when the planning institutions have not yet firmly committed themselves to certain solutions.

It is useful to begin by defining common core objectives across sectors and government levels in order to facilitate bringing the planning units together. These objectives will be cross-cutting in the case of biodiversity conservation and climate change, involving the flow of environmental services and benefiting human well-being. Application of objectives and impacts (positive and negative) will likely be unique to each sector and its mission, finances, and capacity. The process of defining common core objectives requires use of the best available scientific information in both the natural and social sciences so as to understand needs, opportunities, risks and uncertainties over the long term, as affecting each sector's plan to achieve its relative goals of sustainable development.

Coordination and balancing of public and private interests is key for effective spatial planning to ensure efficient patterns of spatial development and equitable economic benefits across the jurisdictions. These aspects will also help secure local support and a framework of certainty about the future for private and public investments. Since it is difficult to change land/marine use once land/marine space is significantly changed and infrastructure is in place, various development needs should be coordinated in advance. Otherwise, inefficient and unequitable patterns of development may occur. Because land/sea/resource use decisions by an individual landowner or rightsholder inevitably affects other people and economic or other interests, policy makers need to respond by implementing taxes, subsidies, and other policies that discourage actions with negative externalities and encourage actions with positive externalities.

Integration of conservation plans into spatial plans is essential for a planning process that fully and accurately incorporates biodiversity conservation objectives as part of the plan. Most government sectors (e.g., energy, mining, agriculture, fisheries, urban affairs, health, housing, commerce, transportation) have space-related responsibilities and associated planning requirements that include elements directly or indirectly affecting biodiversity and ecosystems at various levels. Those plans are generated from sectors guided by different ministries or departments. Integration and harmonization reinforces common goals, reduces conflicts and redundancies, ensures more efficient use of existing resources, and advances efforts for sustainable development.

Identifying the specific aspects of biodiversity needing reflection in other sector plans is key. The important thing for biodiversity is to have clarity about what aspects of other ministerial planning responsibilities are likely to impinge on biodiversity and, flowing from that determination, what information about biodiversity they should consider in their respective plans. Collaboration across parts of government is needed to do this.

Planners must navigate diverse interests about how to sustainably use and conserve land/sea areas, both now and in the future. Under modernized spatial planning systems, planners need good information, including reliable geo-spatial data, about surface areas and changes with time, legally-grounded authority and responsibility to prepare a well-balanced plan, and provide advice on its implementation. In this process, multiple objectives must be considered, including economic competitiveness, environmental sustainability, and social inclusion - essential aspects for sustainable development. 
Professional planners need resource support and training to be effective in spatial planning. Particularly at the local level, planning staff need hands-on training about how to apply planning principles, including the ecosystem approach, for their local circumstances. Planning authorities need legal and outreach tools to mobilize participation of all stakeholders, appropriately use available information and local knowledge, and endeavor to understand and incorporate the biodiversity and ecosystem values at stake. Working with conservation practitioners and other sector staff, professional planners will always play a major role in building adequate provisions into the integrated plans for compatible uses and protections of valuable ecosystems and biodiversity-areas, including Key Biodiversity Areas, and agriculture lands, forests, wetlands, deserts, grasslands, montane, coastal zones, and marine areas under sustainable use practices.

Integrated spatial planning must include scenarios for anticipated global change impacts, locally and nationally, particularly for climate change. Tools for implementation of the best agreedupon scenarios, must go beyond regulation to include other tools such as voluntary compliance, community monitoring, and stakeholder support for implementation. The resulting plan must have flexibility to adjust scenarios based on new information, while avoiding as much environmental harm as possible, and still advancing biodiversity goals and building ecosystem resilience.

The ultimate goal and ongoing challenge is to use integrated spatial planning and management, among the basket of other law, policy, economic, and social tools, to help reverse the continuing loss of global, transnational, and national biodiversity, mitigate climate change and improve knowledge and capacity to understand adaptation needs of species and ecosystems, as well as the built environment. These gains are only possible by using best available science and observational technologies to keep current on the state of knowledge and change, whether on land or sea, and ensuring meaningful public participation and stakeholder communication throughout. 


\section{References and additional sources of information}

Ahmed, K. (2012). Getting to green: a sourcebook of pollution management policy tools for growth and competitiveness. Washington, DC: World Bank.

Allmendinger, P. and G. Haughton (2009). 'Commentary: Critical reflections on spatial planning'. Environment and Planning A 41:2544-2849.

Allmendinger, P. and G. Haughton (2010). 'Spatial Planning, Devolution, and New Planning Spaces'. Environment and Planning C: Politics and Space 28(5):803-818. Available at: https://doi. org/10.1068/c09163.

Allmendinger, P. and G. Haughton (2013). 'Revisiting ... Spatial planning, devolution, and new planning spaces'. Environment and Planning C: Politics and Space 31(6):953-957. Available at: https://doi.org/10.1068/c3106.

Baldwin, R.F., S.C. Trombulak, P.B. Leonard, R.F. Noss, J.A. Hilty, H.P. Possinghom, L. Scarlett, and M.G. Anderson (2018). 'The Future of Landscape Conservation'. BioScience, vol. 68 No. 2.

Bennett, G. (2004). Integrating Biodiversity Conservation and Sustainable Use: Lessons Learned from Ecological Networks. Gland, Switzerland and Cambridge, UK: IUCN. Available at: https:// portals.iucn.org/library/node/8355.

Borrini-Feyerabend, G. (1996). Collaborative Management of Protected Areas: Tailoring the Approach to the Context. Gland, Switzerland: IUCN. Available at: https://portals.iucn.org/library/ node/7041.

Borrini-Feyerabend, G., Dudley, N. Jaeger, T., Lassen, B., Pathak Broome, N., Phillips, A. and Sandwith, T. (2013). Governance of Protected Areas: From understanding to action. Best Practice Protected Area Guidelines Series No. 20. Gland, Switzerland: IUCN. Available at: https://portals. iucn.org/library/node/29138.

Breitburg, D., Grégoire, M., and Isensee, K. (eds). (2018). The ocean is losing its breath: Declining oxygen in the world's ocean and coastal waters. IOC-UNESCO, Global Ocean Oxygen Network. IOC Technical Series, No. 137.

Census of Marine Life International Secretariat (2010). Scientific results to support the sustainable use and conservation of marine life. Summary for decision makers (Census Summary). Available at: http://www.coml.org/comlfiles/policy/ENGLISH_Policy_Report_reduced.pdf (Accessed: 18 August 2018).

Convention on Biological Diversity (CBD) (2010). The Strategic Plan for Biodiversity 2011-2020 and the Aichi Biodiversity Targets. Decision adopted by the Conference of the Parties to the Convention on Biological Diversity at its Tenth Meeting. X/2. UNEP/CBD/COP/DEC/X/2 (29 October 2010). Available online at: https://www.cbd.int/decision/cop/?id=12268.

Convention on Biological Diversity (CBD) (2009). Connecting Biodiversity and Climate Change Mitigation and Adaptation: Report of the Second Ad Hoc Technical Expert Group on Biodiversity and Climate Change. Technical Series No. 41. Montreal: CBD.

Council of Europe (CEMAT) (2000). Guiding Principles for Sustainable Spatial Development of the European Continent. Adopted at the $12^{\text {th }}$ Session of the European Conference of Ministers 
responsible for Regional Planning on 7-8 September 2000 in Hannover. Available at: http:// www.mdrap.ro/_documente/dezvoltare_teritoriala/documente_strategice/Sustainable\%2 Spatial\%20Development.pdf.

Council of Europe Committee of Ministers (CEC) (1984). 'European Regional/Spatial Planning Charter', Recommendation No. R (84) 2.

Cross, M.S., Hilty, J.A., Tabor, G.M., Lawler, J.J., Graumlich, L.J. and Berger, J. (2011). 'From connect-the-dots to dynamic networks: maintaining and restoring connectivity as a strategy to address climate change impacts on wildlife'. In: J. Brodie, E. Post and D. Doak (eds.) Wildlife Conservation in a Changing Climate. Chicago, IL.: University of Chicago Press.

Dalhammer, E., Gaugitsch, R., Neugebauer, W., and Bohme, K. (2018). Spatial planning and governance within EU policies and legislation and their relevance to the New Urban Agenda. European Union and the Committee of the Regions. Available at: https://cor.europa.eu/en/engage/studies/ Documents/Spatial-planning-new-urban-agenda.pdf.

Daniels, T., and Daniels, K. (2003). The Environmental Planning Handbook for Sustainable Communities and Regions. Chicago, IL.: American Planning Association, Planners Press.

De la Fuente, B., Mateo-Sanchez, M.C., Rodriguez, G. Gaston, A., Perez de Ayala, R., Colomina-Perez, D., Melero, M. and Saura, S. (2018). 'Natura 2000 sites, public forests and riparian corridors: The connectivity backbone of forest Green infrastructure'. Land Use Policy 75:429-441. Available at: https://doi.org/10.1016/j.landusepol.2018.04.002.

Department of Environment, Food, and Rural Affairs (DEFRA) (2010). Delivering a healthy natural environment. An update to "Securing a healthy natural environment: An action plan for embedding an ecosystems approach. London: UK Government. Available at https://ecosystemsknowledge. net/sites/default/files/wp-content/uploads/Defra\%20healthy-nat-environ.pdf.

Doswald, N. and Osti, M. (2011). Ecosystem-based approaches to adaptation and mitigation - good practice examples and lessons learned in Europe. Bonn, Germany: Federal Ministry of Environment.

Dudley, N. (ed.) (2008). Guidelines for Applying Protected Area Management Categories. Gland, Switzerland: IUCN. WITH Stolton, S., Shadie, P. and Dudley, N. (2013). IUCN WCPA Best Practice Guidance on Recognising Protected Areas and Assigning Management Categories and Governance Types, Best Practice Protected Area Guidelines Series No. 21, Gland, Switzerland: IUCN. Available at: https://doi.org/10.2305/IUCN.CH.2008.PAPS.2.en.

Ecologic Institute (2011). 'Green Infrastructure projects and policies'. Background and agenda. Expert workshop, Brussels, September 2011. Available at: http://ecologic.eu/files/attachments/ presentation/2011/gi-expert_ws_agenda_07sept2011.pdf. (Accessed: 30 September 2018).

Ehler, C., and Douvere, F. (2009). Marine Spatial Planning: A Step-by-Step Approach toward Ecosystem-based Management. Intergovernmental Oceanographic Commission (IOC) and Man and the Biosphere Programme. IOC Manual and Guides No. 53. Paris: UNESCO. Available at: http:// unesdoc.unesco.org/images/0018/001865/186559e.pdf.

European Commission (EC) (2017). Joint Roadmap to accelerate Maritime/Marine Spatial Planning processes worldwide (MSP). Adopted by the European Commission and IOC-UNESCO during the $2^{\text {nd }}$ International Conference on Marine/Maritime Spatial Planning, 15-17 March 2017, Paris 
UNESCO Headquarters. Available at: https://en.unesco.org/.

European Commission (EC) Directorate-General for Maritime Affairs and Fisheries (2009). Legal aspects of maritime spatial planning: Summary report. Luxembourg: Office of Publications of the European Communities.

European Commission (EC) (1997). The EU compendium of spatial planning systems and policies. Regional Development Studies. Luxembourg: CEC.

European Union (EU) (2018). Press release. Available at: https://ec.europa.eu/maritimeaffairs/sites/ maritimeaffairs/files/newsroom/msp1_33100_0.jpg.

European Union (EU) (2014). Directive 2014/89/EU of the European Parliament and of the Council establishing a framework for maritime spatial planning. Official Journal of the European Union: Brussels.

European Union (EU) (2008). Directive 2008/56/EC of the European Parliament and of the Council establishing a framework for community action in the field of marine environmental policy (Marine Strategy Framework Directive). Official Journal of the European Union: Brussels.

Farrier, D. and Harvey, M., Teles da Silva, S., Diegues Leuzinger, M., Verschuuren, J., Gromilova, M., Trouwborst, A. and Ross Paterson, A. (2013). The Legal Aspects of Connectivity Conservation: Case Studies. IUCN Environmental Policy and Law Paper No. 85, vol. 2. Gland, Switzerland: IUCN. Available at: https://portals.iucn.org/library/node/30283.

Fidelis, T. and Sumares, D. (2008). 'Nature Conservation and Urban Development Control in the Portuguese Planning System: a New Impetus Against Old Praxis?' European Environment 18:298311. Available at: https://doi.org/10.1002/eet.487.

Franklin, A.B., B.R. Noon, and T.L. George (2002). 'What is Habitat Fragmentation?' Studies in Avian Biology 25:20-29.

Game, E.T., Kareiva, P., and Possingham, H.P. (2012). 'Six Common Mistakes in Conservation Priority Setting'. Conservation Biology 27(3):480-485. Available at: https://doi.org/10.1111/cobi.12051.

Gjerde, K., Nordtvedt Reeve, L. L., Harden-Davies, H., Ardron, J., Dolan, R., Durussel, C., Earle, S., Jimenez, J. A., Kalas, P., Laffoley, D., Oral, N., Page, R., Riberiro, C., Rochette, J., Spadone, A., Thiele, T., Thomas, H. L., Wagner, D., Warner, R. M., Wilhelm, A. and Wright G. (2016). 'Protecting Earth's last conservation frontier: scientific, management and legal priorities for MPAs beyond national boundaries'. Aquatic Conservation: Marine and Freshwater Ecosystems 26(Suppl. 2):45-60. Available at: https://doi.org/10.1002/aqc.2646.

Global Biodiversity Information Facility (GBIF) (2018). Available at: https://www.gbif.org (Accessed: 23 July 2018).

Gret-Regamey, A., Altwegg, J., Siren, E.A. and van Strien, M.J. (2017). 'Integrating ecosystem services into spatial planning - A spatial decision support tool'. Landscape and Urban Planning 165:206-219. Available at: https://doi.org/10.1016/j.landurbplan.2016.05.003.

Groves, C. and Game, E. T. (2016). Conservation planning: informed decisions for a healthier planet. Greenwood Village, Colorado: Roberts and Company Publishers.

Haaren, C. V., Galler, C. and Ott, S. (2008). Landscape planning: the basis of sustainable landscape development. Bonn, Germany: BfN/Federal Agency for Nature Conservation. 
Hannah, L., Midgley, G., Hughes, G., and Bomhard, B. (2005). 'The View from the Cape: Extinction Risk, Protected Areas, and Climate Change'. BioScience 55(3). Available at: https://doi. org/10.1641/0006-3568(2005)055[0231:TVFTCE]2.0.CO;2.

Hardy, D. (1991). From Garden Cities to New Towns: Campaigning for Town and Country Planning, 1899-1946. London, UK: Chapman \& Hall. Available at: https://doi.org/10.4324/9780203451267.

Hilty, J.A., W. Z. Lidicker Jr., and A. M. Merenlender (2006). Corridor Ecology: The Science and Practice of Linking Landscapes for Biodiversity Conservation. Washington, DC, USA: Island Press.

Intergovernmental Panel on Climate Change (IPCC) (2014). Climate Change 2014: Synthesis Report. Contribution of Working Groups I, II and III to the Fifth Assessment Report of the Intergovernmental Panel on Climate Change [Pachauri, R.K. and L.A. Meyer (eds.)]. Geneva, Switzerland: IPCC.

Intergovernmental Panel on Climate Change (IPCC) (2014a). 'Summary for Policymakers'. In: Climate Change 2014: Mitigation of Climate Change, pp. 117-130. Contribution of Working Group III to the Fifth Assessment Report of the Intergovernmental Panel on Climate Change [O. Edenhofer, R. Pichs-Madruga, Y. Sokona, E. Farahani, S. Kadner, K. Seyboth, A. Adler, I. Baum, S. Brunner, P. Eickemeier, B. Kriemann, J. Savolainen, S. Schlömer, C. von Stechow, T. Zwickel and J.C. Minx (eds.)]. Cambridge, UK and New York, NY, USA: Cambridge University Press.

Intergovernmental Panel on Climate Change (IPCC) (2014b). 'Annex II: Glossary' [Mach, K.J., Planton, S. and von Stechow, C. (eds.)]. In: Climate Change 2014: Synthesis Report. Contribution of Working Groups I, II and III to the Fifth Assessment Report of the Intergovernmental Panel on Climate Change [R.K. Pachauri and L.A. Meyer (eds.)]. Geneva, Switzerland: IPCC.

International Union for Conservation of Nature (IUCN) Commission on Environmental Law (CEL) (2000). Landscape Conservation Law: Present Trends and Perspectives in International and Comparative Law. Proceedings of a Colloquium commemorating the $50^{\text {th }}$ Anniversary of IUCN, The World Conservation Union 30 October 1998, Paris. IUCN Environmental Policy and Law Paper No. 39. Gland, Switzerland: IUCN. Available at: https://portals.iucn.org/library/node/7699.

Jones, P.J.S., Lieberknecht, L.M. and Qiu, W. (2016). 'Marine spatial planning in reality: Introduction to case studies and discussion of findings'. Marine Policy 71:256-264. Available at: https://doi. org/10.1016/j.marpol.2016.04.026.

Jones, P.J.S., Lieberknecht, L.M. and Qiu, W. (2016). 'Marine spatial planning in reality: Introduction to case studies and discussion of findings'. Marine Policy 71:26-264.

Kubiszewski, I., Costanza, R., Anderson, S. and Sutton, P. (2017). 'The future value of ecosystem services: Global scenarios and national implications'. Ecosystem Services 26:289-301. Available at: https://doi.org/10.1016/j.ecoser.2017.05.004.

Kukkala, A. (2017). Spatial conservation planning for biodiversity and ecosystem services - from concepts and methods to policy agendas in the European Union. Academic dissertation, University of Helsinki. Available at: https://helda.helsinki.fi/handle/10138/178874.

Land Use Consultants (2006). 'A practical toolkit for assessing cumulative effects of spatial plans and development projects on biodiversity in England'. English Nature Research Reports No. 673. Available online at: http://publications.naturalengland.org.uk/publication/64008?category $=47017$. 
Lausche, B. (2011). Guidelines for Protected Areas Legislation. IUCN Environmental Policy and Law Paper No. 81. Gland, Switzerland: IUCN. Available at: https://portals.iucn.org/library/node/9869. Lausche, B. (2013). The Legal Aspects of Connectivity Conservation. A Concept Paper. IUCN Environmental Policy and Law Paper No. 82, vol. 1. Gland, Switzerland: IUCN. Available at: https:// portals.iucn.org/library/node/10421.

Lausche, B., Farrier, D., Verschuuren, J., La Viña, A. G. M., Trouwborst, A., Hubert Born, C. and Aug, L. (2013). The Legal Aspects of Connectivity Conservation: Case Studies. IUCN Environmental Policy and Law Paper No. 82, vol. 2. Gland, Switzerland: IUCN. Available at: https://portals.iucn. org/library/node/30283.

Levin, N., Kark, S. and Danovaro, R. (2018). 'Adding the Third Dimension to Marine Conservation'. Conservation Letters - A journal of the Society of Conservation Biology 11(3):1-14.

Maes, F. (2008). 'The international legal framework for marine spatial planning'. Marine Policy 32:797810. Available at: https://doi.org/10.1016/j.marpol.2008.03.013.

Marine Ecosystem-Based Management. http://www.natureserve.org/conservation-tools/ecosystem-based-management-tools-network.

Marine Ecosystem-Based Management. http://www.natureserve.org/conservation-tools/ecosystem-based-management-tools-network.

Marine Protected Areas (MPA) Federal Advisory Committee (2017). Harnessing Ecological Spatial Connectivity for Effective Marine Protected Areas and Resilient Marine Ecosystems: Scientific Synthesis and Action Agenda. Washington, DC: NOAA. Available at: https://nmsmarineprotectedareas.blob.core.windows.net/marineprotectedareas-prod/media/archive/fac/products/connectivity-report-combined.pdf.

Menegon, S., Depellegrin, D., Farella, G., Gissi, E., Ghezzo, M., Sarretta, A.I., Venier, C. and Barbanti, A. (2018). 'A modelling framework for MSP-oriented cumulative effects assessment'. Ecological Indicators 91:171-181. Available at: https://doi.org/10.1016/j.ecolind.2018.03.060.

Metternicht, G. (2017). Global Land Outlook Working Paper: Land Use Planning. Sydney, Australia: University of New South Wales. Available at: https://research.unsw.edu.au/people/professor-graciela-isabel-metternicht.

Metternicht, G. (2018). Land Use and Spatial Planning: Enabling Sustainable Management of Land Resources. Springerbriefs in Earth Sciences series. Springer International Publishing. Available at: https://doi.org/10.1007/978-3-319-71861-3.

Millennium Ecosystem Assessment (MEA) (2005). Ecosystems and Human Well-being: Synthesis. Washington, DC: Island Press. Available at: https://www.millenniumassessment.org/documents/document.356.aspx.pdf.

Ministry of Infrastructure and Environment (2013). Summary National Policy Strategy for Infrastructure and Spatial Planning: Making the Netherlands competitive, accessible, liveable and safe. Available at: https://www.government.nl/documents/publications/2013/07/24/summary-national-policy-strategy-for-infrastructure-and-spatial-planning.

Muller-Karger, F.E., Miloslavich, P., Bax, N.J., Simmons, S., Costello, M. J., Sousa Pinto, I., Canonico, G., Turner, W., Gill, M., Montes, E., Best, B. D., Pearlman, J., Halpin, P., Dunn, D., Benson, A., Martin, C. S., Weatherdon, L.V., Appeltans, W., Provoost, P., Klein, E., Kelble, C.R., Miller, R.J., 
Chavez, F.P., Iken, K., Chiba, S., Obura, D., Navarro, L.M., Pereira, H.M., Allain, V., Batten, S., Benedetti-Checchi, L., Emmett Duffy, J., Kudela, R.M., Rebelo, L-M., Shin, Y., and Geller, G. (2018). 'Advancing Marine Biological Observations and Data Requirements of the Complementary Essential Ocean Variables (EOVs) and Essential Biodiversity Variables (EBVs) Frameworks'. Frontiers in Marine Science vol. 5, article 211.

National Academies of Sciences, Engineering, and Medicine (NAS) (2015). 'Active Earth Remote Sensing for Ocean Applications' (chapter 3). In: A Strategy for Active Remote Sensing Amid Increased Demand for Radio Spectrum, pp. 54-76. Washington, DC: National Academies Press.

National Oceanic and Atmospheric Administration (NOAA) Ecosystem Science and Management Working Group (2011). Strategic Advice on Designing and Implementing Coastal and Marine Spatial Plans: Report to the NOAA Science Advisory Board. Available at: ftp://ftp.oar.noaa.gov/ SAB/sab/reports/CMSP\%20Report\%20to\%20NOAA\%20Final.pdf.

National Oceanic and Atmospheric Administration (NOAA) Ocean Science Service. Available at: https://oceanservice.noaa.gov/facts/ecosci.html. (Accessed: 8 June 2018).

National Oceanic and Atmospheric Administration (NOAA) Coastal and Marine Spatial Planning. Available at: https://cmsp.noaa.gov/resources.html\#key-documents.

Neugarten, R.A., Langhammer, P.F., Osipova, E., Bagstad, K.J., Bhagabati, N., Butchart, S.H.M., Dudley, N., Elliott, V., Gerber, L.R., Gutierrez Arrellano, C., Ivanić, K.-Z., Kettunen, M., Mandle, L., Merriman, J.C., Mulligan, M., Peh, K.S.-H., Raudsepp-Hearne, C., Semmens, D.J., Stolton, S. and Willcock, S. (2018). Tools for measuring, modelling, and valuing ecosystem services: guidance for key biodiversity areas, natural World Heritage Sites, and protected areas. Best Practice Protected Areas Guidelines Series, No. 28. Gland, Switzerland: IUCN. Available at: https://doi. org/10.2305/IUCN.CH.2018.PAG.28.en.

Nolon, J.R. (2006). 'Historical Overview of the American Land Use System: A Diagnostic Approach to Evaluating Governmental Land Use Control'. Pace Envtl. L. Rev. 23(821). Available at http:// digitalcommons.pace.edu/lawfaculty/459/.

Okeke D.C. (2015). 'African Approaches to Spatial and Green Planning'. Agriculture, Forestry and Fisheries 4(4-1):6-13. Available at: https://doi.org/10.11648/j.aff.s.2015040401.12.

Partnership for Action on Green Economy (PAGE) (2016). Integrated Planning and Sustainable Development: Challenges and Opportunities. Synthesis Report. New York: UNDP.

Piper, J.M., Wilson, E.B., Weston, J., Thompson, S. and Glasson, J. (2006). 'Spatial planning for biodiversity in our changing climate'. English Nature Research Reports, No. 677. Oxford Institute for Sustainable Development. Available at: publications.naturalengland.org.uk/file/71011.

Pressey, R.L., Cabeza, M., Watts, M. E., Cowling, R. M., and Wilson, K.A. (2007). 'Conservation planning in a changing world'. Trends in Ecology and Evolution 22:583-592. Available at: https://doi. org/10.1016/j.tree.2007.10.001.

Quu, W. and Jones, P.J.S. (2013). 'The emerging policy landscape for marine spatial planning in Europe'. Marine Policy 39:182-190. Available at: https://doi.org/10.1016/j.marpol.2012.10.010. 
Ritchie Chung, B. (1999). 'Community-based Land Use Planning in Conservation Areas - Lessons from Local Participatory Processes that Seek to Balance Economic Uses with Ecosystem Protection'. Training Manual, America Verde No. 3. Arlington, VA, USA: The Nature Conservancy.

Samper, A. (2012). 'Guidance Notes on Tools for Pollution Management'. In: Ahmed, K. Getting to green: a sourcebook of pollution management policy tools for growth and competitiveness, pp. 70-76. Washington, DC: World Bank. Available at: http://documents.worldbank.org/curated/ en/560021468330349857/Getting-to-green-a-sourcebook-of-pollution-management-policytools-for-growth-and-competitiveness.

Scherr, S.J., and McNeely, J.A. (2007). 'Biodiversity conservation and agricultural sustainability: towards a new paradigm of 'ecoagriculture' landscapes'. Philosophical Transactions of the Royal Society B (2008):477-494. Available at: https://doi.org/10.1098/rstb.2007.2165.

Scott, A., Carter, C., Hardman, M., Grayson, N. and Slaney, T. (2018). 'Mainstreaming ecosystem science in spatial planning practice: Exploiting a hybrid opportunity space'. Land Use Policy 70:232-246. Available at: https://doi.org/10.1016/j.landusepol.2017.10.002.

Seidl, I, Tisdell, C., and Harrison, St. (2001). 'Environmental Regulations of Land-Use and Public Compensation: Principles with Swiss and Australian Examples'. Working paper No. 56 on Economics, Ecology and the Environment. University of Queensland, Australia: School of Economics. Available at: https://trove.nla.gov.au/work/1322586?q\&versionld=184625619.

Stead, D. (2012). 'Convergence, Divergence, or Constancy of Spatial Planning? Connecting Theoretical Concepts with Empirical Evidence from Europe'. Journal of Planning Literature 28(1:19-31. Available at: http://journals.sagepub.com/doi/abs/10.1177/0885412212471562.

Stead, D. and Meijers, E. (2009). Spatial Planning and Policy Integration: Concepts, Facilitators and Inhibitors. Planning Theory \& Practice vol. 10(3):317-332. Available at: https://doi. org/10.1080/14649350903229752.

Tewdwr-Jones, M., Gallent, N., and Morphet, J. (2010). 'An Anatomy of Spatial Planning: Coming to Terms with the Spatial Element in UK Planning'. Journal of European Planning Studies 18(2):239257. Available at: https://doi.org/10.1080/09654310903491572.

United Nations Department of Economic and Social Affairs (UN DESA) (2018). World Urbanization Prospects: Key Facts. Population Division. Available at: https://esa.un.org/unpd/wup/Publications/Files/WUP2018-KeyFacts.pdf.

United Nations Educational, Scientific and Cultural Organization (UNESCO) (2017). Declaration of Ethical Principles in Relation to Climate Change. Paris, France. Available at: http://unesdoc. unesco.org/images/0026/002601/260129e.pdf.

United Nations Educational, Scientific and Cultural Organization Intergovernmental Oceanographic Commission (UNESCO IOC) (2014). Guide to Evaluating Marine Spatial Plans. IOC Manual and Guides No. 70. Paris: UNESCO. Available at: http://unesdoc.unesco.org/images/0022/002277/227779e.pdf.

United Nations Framework Convention on Climate Change (UNFCCC) Paris Agreement. Paris, 12 December 2015. Entered into force: 4 November 2016. Official text available at: https://treaties. un.org/doc/Treaties/2016/02/20160215\%2006-03\%20PM/Ch_XXVII-7-d.pdf. 
United Nations General Assembly (UNGA) (2015). Transforming our world: the 2030 agenda for sustainable development. Decision A/RES/70/1. New York, NY: United Nations.

United Nations Institute for Training and Research (UNITAR) (2018). Integrated Planning for Climate Change and Biodiversity. Online free course described at: https://www.unitar.org/event/full-catalog/integrated-planning-climate-change-and-biodiversity-0.

Vettoretto, L. (2009). 'A Preliminary Critique of the Best and Good Practices Approach in European Spatial Planning and Policy-making'. European Planning Studies vol. 17, no. 7. Available at: https://doi.org/10.1080/09654310902949620.

Walsh, C., Jacuniak-Suda, M., Knieling, J. and Othengrafen, F. (2012). Soft spaces in spatial planning and governance: Theoretical reflections and definitional issues. Prepared as part of an international project on 'Soft Spaces, Spatial Planning and Territorial Management in Europe', led by HafenCity, University of Hamburg. Available at: https://www.researchgate.net/publication/256461649_SOFT_SPACES_IN_SPATIAL_PLANNING_AND_GOVERNANCE_THEORETICAL_REFLECTIONS_AND_DEFINITIONAL_ISSUES.

Wilson, E. and Piper, J. (2008). Spatial Planning for Biodiversity in Europe's Changing Climate. European Environment 18:135-151. Available at: https://www.researchgate.net/publication/229476707_ Spatial_planning_for_biodiversity_in_Europe's_changing_climate.

Worboys, G. L., W. L. Francis, and M. Lockwood (2010). Connectivity Conservation Management: A Global Guide. London, UK: Earthscan.

World Wide Fund for Nature (WWF) (2015). Living Blue Planet Report. Species, habitats and human well-being. [Tanzer, J., Phua, C., Lawrence, A., Gonzales, A., Roxburgh, T., and Gamblin, P. (eds.)]. Gland, Switzerland: WWF. Available at: https://www.worldwildlife.org/publications (Accessed: 23 August 2018).

Wright, G., Gjerde, K.M., Johnson, D.E., Finkelstein, A., Adelaide Ferreira, M., Dunn, D.C., Rodriguez Chaves, M. and Grehan, A. (2018). Marine spatial planning in areas beyond national jurisdiction. Issue Brief. Paris, France: IDDRI.

Wright, G., Rochette, J., Gjerde, K. and Seeger, I. (2018). The long and winding road: negotiating a treaty for the conservation and sustainable use of marine biodiversity in areas beyond national jurisdiction. IDDRI Studies No. 08/18. 



\section{IUCN}

IUCN Environmental Law Programme

Environmental Law Centre

Godesberger Allee 108-112

53175 Bonn, Germany

Phone: ++ 49228 / 2692231

Fax: $\quad++49228$ / 2692246

elcsecretariat@iucn.org

www.iucn.org/law 